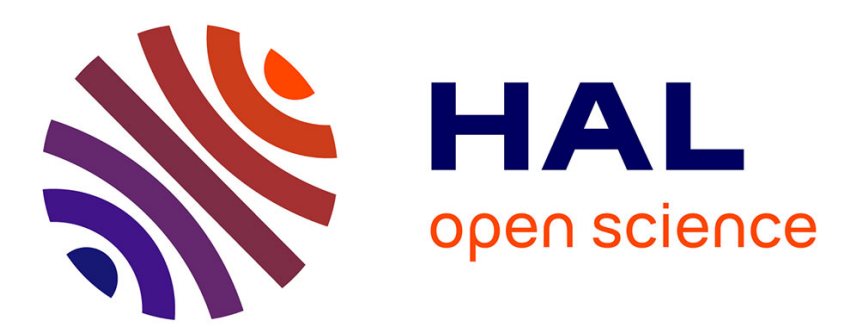

\title{
Early subduction dynamics recorded by the metamorphic sole of the Mt. Albert ophiolitic complex (Gaspé, Quebec)
}

Benoît Dubacq, Mathieu Soret, Ella Jewison, Philippe Agard

\section{- To cite this version:}

Benoît Dubacq, Mathieu Soret, Ella Jewison, Philippe Agard. Early subduction dynamics recorded by the metamorphic sole of the Mt. Albert ophiolitic complex (Gaspé, Quebec). Lithos, 2019, 334-335, pp.161-179. 10.1016/j.lithos.2019.03.019 . hal-02187161

\section{HAL Id: hal-02187161 https: / hal.sorbonne-universite.fr/hal-02187161}

Submitted on 17 Jul 2019

HAL is a multi-disciplinary open access archive for the deposit and dissemination of scientific research documents, whether they are published or not. The documents may come from teaching and research institutions in France or abroad, or from public or private research centers.
L'archive ouverte pluridisciplinaire HAL, est destinée au dépôt et à la diffusion de documents scientifiques de niveau recherche, publiés ou non, émanant des établissements d'enseignement et de recherche français ou étrangers, des laboratoires publics ou privés. 


\section{EARLY SUBDUCTION DYNAMICS RECORDED BY THE}

\section{METAMORPHIC SOLE OF THE MT ALBERT OPHIOLITIC}

3

\section{COMPLEX (GASPÉ, QUEBEC)}

4

5Benoît Dubacq ${ }^{1, *}$, Mathieu Soret ${ }^{1,2}$, Ella Jewison ${ }^{1}$, Philippe Agard ${ }^{1}$

6

71 Sorbonne Université, CNRS-INSU, Institut des Sciences de la Terre de Paris, ISTeP UMR 7193, F875005 Paris, France

9

102 University of British Columbia, Okanagan, Earth, Environmental and Geographic Sciences 11Kelowna, BC, Canada

12

13* corresponding author: Benoit.Dubacq@sorbonne-universite.fr

14

15Keywords: metamorphic sole; subduction initiation; thermobarometry; Mont Albert; metamorphic 16petrology

17 


\section{INTRODUCTION}

19Understanding the mechanisms of emplacement of ophiolites has been the subject of decades of 20studies focused on the sole of these ophiolites (Williams and Smith, 1973; Searle and Malpas, 1982; 21Spray et al., 1984; Jamieson, 1986; Hacker, 1991; Mahmood et al., 1995; Gnos, 1998; Dimo-Lahitte et 22al., 2001; Ishikawa et al., 2005; Cowan et al., 2014; Rioux et al., 2016; amongst many others). 23Ophiolite soles are generally thin $(<500 \mathrm{~m})$ portions of heavily deformed peridotite and 24metamorphosed oceanic crust, found at the base of most large-scale ophiolites. Their present-day 25structure results from the stacking of three main units: one of mantle origin and two of crustal origin. 26Figure 1 presents a conceptualised frame for the formation of ophiolite soles during subduction 27infancy. The top of the sole, found beneath porphyroclastic peridotite, is typified by tectonized 28harzburgite with a mylonitic to ultramylonitic overprint, common occurrence of secondary 29clinopyroxene, amphibole and late serpentine. The median and lower units of the sole are 30metamorphic rocks of mainly mafic nature, with metamorphic grade decreasing downwards. These 31two units are commonly referred to as 'metamorphic sole', and originate from oceanic crust. They are 32interpreted as sea-floor mafics and sediments re-crystallising at depth, immediately below the nascent 33mantle wedge, within the first few million years of the life of the subduction/obduction system (e.g., 34Dewey, 1976; Wakabayashi and Dilek, 2000, 2003): the top of the subducted oceanic plate is 35metamorphosed up to granulite facies against the still hot overlying peridotite, and accreted to the base 36of the future ophiolite when the rheological contrast between the two is minimum (Agard et al., 2016 37and Fig. 1 a-b). This allows exhumation of the sole together with the ophiolitic body, as subduction 38proceeds until obduction (Fig. 1c). The consistency of ductile strain in the high-grade metamorphic 39rocks of the sole and in the deformed peridotite (top of the sole) has led numerous authors to suggest 40these units share common history (e.g. Searle \& Malpas, 1980; Boudier et al., 1982; Spray, 1984; 41Jamieson, 1986; Prigent et al., 2018), including exhumation. In this model, burial of the oceanic crust 42and exhumation of the sole are fast, which is supported by dating (e.g., Hacker and Mosenfelder, 431996; Hacker et al., 1996). Later blueschist facies metamorphism is observed in margin units 44originating further away from the trench (as for the Saih Hatat region in Oman, e.g. Agard et al., 2010) 
45and less frequently in the metamorphic sole itself (Wakabayashi, 1990; Plunder et al., 2016), an 46evidence of cooling of the geothermal gradient over time. In this general scheme, the metamorphic 47rocks originating from subducted oceanic crust contain essential information about ophiolite 48emplacement and geological processes occurring at the plate interface in nascent subduction zones. In 49the overlying peridotite, information is lacking or much less precise in terms of evaluating strain 50mechanisms, estimating geothermal gradients (through thermobarometry) and dating (with e.g. U-Pb 51radiochronology on granitoid rocks from slab melting, ${ }^{40} \mathrm{Ar} /{ }^{39} \mathrm{Ar}$ on amphibole). Chemical exchange 52from crust-derived metamorphic rocks to peridotites at the base of ophiolitic massifs has also been 53documented as a proxy to mantle wedge metasomatism and linked to dehydration reactions in 54metamorphic soles together with deformation and refertilisation of the peridotite (e.g. Ishikawa et al., 552005; Linckens et al., 2011; Soret et al., 2016; Prigent et al., 2018).

56Continued petrological and structural work, largely based on the Cenomanian Semail ophiolite (in 57Oman and United Arab Emirates) but also carried out on much older ophiolites such as found in the 58Ordovician Bay of Islands complex (see compilation in Agard et al., 2016), has revealed impressive 59consistency in the peak metamorphic conditions of metamorphic soles, with an apparent inverted 60metamorphic gradient. The high-temperature unit at the top of the metamorphic sole is 61metamorphosed and accreted first, around $1 \mathrm{GPa}$ and $850^{\circ} \mathrm{C}$, then the lower unit is accreted around 0.5 $62 \mathrm{GPa}$ and $550^{\circ} \mathrm{C}$. Soret et al. (2017) have shown that this process has been acting repetitively for step63wise accretion of subunits within the high-temperature unit of the Semail ophiolite. Interestingly, and 64in line with the consistency of pressure-temperature estimates between and within metamorphic soles, 65no evidence has been found for a link with the paleo-location of the ridge crest of the structurally 66overlying ophiolitic units: in Oman, metamorphic sole is found on both sides of the paleo-ridge, with 67identical conditions of crystallisation.

68Despite progress on thermodynamic models for amphibole and mafic systems (see Green et al., 2016; 69Palin et al., 2016), large uncertainties remain on the depth of accretion and on pressure-temperature70time paths of metamorphic soles due to their chiefly mafic nature (making thermobarometry imprecise 71compared to metapelites). In the present context of subduction initiation, a counter-clockwise 72pressure-temperature path is expected following general cooling of the geothermal gradient through 
73time, as presented by Hacker and Gnos (1997) or Searle and Cox (1999) for the Semail ophiolite. 74However thermo-mechanical modelling of obduction of this ophiolite (Duretz et al., 2016) yielded 75clockwise pressure-temperature paths for units equivalent to metamorphic soles, with a clockwise 76component increasing away from the plate interface. Yet no clockwise or counter-clockwise 77component was evidenced by Soret et al. (2017) due to limited preservation of the prograde history. 78In this publication, a petrological study of selected sections through the sole of the Mont Albert 79ophiolitic complex (Quebec, Canada) is reported. Although exposure quality is poor due to forest 80cover, the crustal section of the sole appears generally fresh with limited greenschist-facies 81retrogression. The petrology of the sole is similar to that of the Semail ophiolite, with the advantage 82that thin layers of aluminosilicate-bearing metapelites are found scattered within subunits of the Mont 83Albert sole, partly preserving prograde mineral assemblages. The diversity of mineral assemblages in 84metapelites allows deriving robust estimates of the peak metamorphic conditions, consistently with 85thermodynamic modelling of the metamorphism of the mafic rocks. As for the Semail ophiolite, units 86and subunits in the metamorphic sole of the Mont Albert ophiolitic complex appear accreted in a step87wise manner. Estimated pressure-temperature paths are clockwise, with exhumation above the plate 88interface along a warmer thermal gradient than burial. This has implications for the evolution of the 89thermal gradient around the plate interface. Clockwise pressure-temperature paths are reconciled with 90the progressive cooling of the plate interface by rapid accretion and exhumation of metamorphic soles, 91within the first few million years of subduction initiation.

\section{GEOLOGICAL SETTING}

\section{2.1. Structural organization and radiometric constraints}

94The Mont Albert ophiolitic complex (Fig. 2) is located $35 \mathrm{~km}$ south-east of the shore of the Saint 95Lawrence river and the city of Sainte-Anne-des-Monts, in the Gaspé Peninsula of the Quebec province 96of Canada. The Mont Albert ophiolitic complex is an incomplete Ordovician ophiolitic sequence 97(Beaudin, 1983; Gueddari et al., 1999) with peridotite overlying a metamorphic sole mainly composed 98of amphibolite ('amphibolite du diable') showing an apparent inverted metamorphic gradient. A few 99kilometres to the south-west, Mont Paul and Mont du Sud are part of the same ophiolitic system and 100are included in the Mont Albert ophiolitic complex. There is no remnant of crustal rocks above the 
101peridotite, therefore the age of the ophiolitic complex has been constrained in earlier studies with 102radiometric dating carried out on the metamorphic sole and with structural and stratigraphic 103correlation.

104The Mont Albert peridotite and its basal amphibolite are classified in the Dunnage zone and correlated 105to a series of Quebec ophiolites (including from south to north: the Mount Orford, Lac Brompton, 106Asbestos, Thetford Mines ophiolites) via a Taconian suture zone between Laurentia and Lower 107Palaeozoic peri-Laurentian terranes (see Pinet and Tremblay, 1995; Malo et al., 2001, 2008; De Souza 108et al., 2012; Tremblay and Pinet, 2016). This suture zone extends along the Appalachians to western 109Newfoundland, where the Bay of Islands Complex, a klippe of the Dunnage zone, is the most 110complete ophiolite of the orogeny (Cawood and Suhr, 1992). The Dunnage zone represents the 111Ordovician oceanic basin related to the Iapetus ocean and located outboard of the continental passive 112margin of Laurentia defining the Humber zone (Williams, 1979; De Souza et al., 2014). The Mont 113Albert ophiolite and its sole overlay unconformably the Schick-Schock volcanic flows and 114pyroclastics metamorphosed to lower greenschist facies that appear in the internal Humber zone in 115recent publications (reviewed in Tremblay and Pinet, 2016), although Lux (1986) suggested they are 116part of the Dunnage zone. These volcanics are subalkaline tholeiitic basalts of N-MORB-type, with 117geochemical evidence in favour of their eruption in the Humber Zone during the rifting event which 118led to the opening of the Iapetus ocean (Camiré et al., 1995). The Mont Albert ophiolitic complex is 119separated from the upper Ordovician to Devonian sediments and volcanics of the Gaspé Belt to the 120south by a fault zone (Schick-Schock South Fault, Fig. 2) part of the Baie Verte-Brompton Line.

121Radiometric dating using ${ }^{40} \mathrm{Ar} /{ }^{39} \mathrm{Ar}$ by Malo et al. (2008) on amphibole yielded cooling ages in the 122range 457-461 Ma for the highest-grade metamorphic rocks of the sole, crystallisation ages in the 123ranges 454-458 Ma for the lower grade metamorphics of the sole and 455-456 Ma for the greenschist 124facies overprint of the Schick-Schock Group, in agreement with earlier ages (Lux, 1986; Pincivy et al., 1252003). These ages are in the same range as the $456(+/-5) \mathrm{Ma} \mathrm{U} / \mathrm{Pb}$ age obtained among older ages by 126Trzcienski et al. (1995, unreviewed) on zircon from an "unusual magnetite-rich orthopyroxenite layer" 127in the peridotite, as reported by Pincivy et al. (2003) and Tremblay and Pinet (2016). 
129The Mont Albert ophiolitic complex has first been mapped in detail by Alcock (1927) who interpreted 130it as a lenticular magmatic injection, where the surrounding amphibolite was thought representative of 131early magmatic phases, followed by the principal ultramafic body. MacGregor and Basu (1979) 132present a detailed petrographic review of the Mont Albert massif based on extensive sampling and 133electron microprobe analyses carried out in the mid to late 1960s. These authors regard the massif as 134an ultramafic intrusion into the Schick-Schock group, the amphibolite being interpreted as a contact 135metamorphism aureole into which they identified kyanite-bearing gneisses and possible partial melting 136(see also MacGregor, 1964).

137The ophiolitic nature sensu stricto of the Mont Albert massif has been popularised by the study of 138Beaudin (1983). Trzcienski (1988) later suggested that its metamorphic sole was a retrogressed 139eclogite, using the co-existence of garnet and clinopyroxene in the high-temperature unit for the 140terminology but suggesting peak metamorphism around $840^{\circ} \mathrm{C}$ and at least $1.2 \mathrm{GPa}$ to account for the 141presence of kyanite in metasediments - which corresponds to the upper garnet granulite field as 142defined by Spear (1993). In this view, the whole metamorphic sole and peridotite massif were 143subducted and later exhumed along the surrounding faults in the stability field of kyanite (buried along 144a thermal gradient around $16^{\circ} \mathrm{C} / \mathrm{km}$ ). Rejecting the eclogitic nature of the sole in line with other 145authors (e.g. O'Beirne-Ryan et al., 1990), Whitehead et al. (1995) interpreted the amphibolite du 146diable as a dynamothermal sole formed 'in a shear zone within an oceanic domain by the progressive 147underplating of overridden crustal rocks to the base of an overriding oceanic fragment', where shear 148heating implicitly plays a prominent role as heat source. This definition is not necessarily inconsistent 149with current models (e.g. Agard et al., 2016; Rioux et al., 2016) but overlooks the apparent pressure 150gradient and the depth of the process as implied by kyanite, which eases explaining dating 151inconsistencies between initiation of basin closure based on fossil evidence and ${ }^{40} \mathrm{Ar} /{ }^{39} \mathrm{Ar}$ cooling ages 152on the amphibolite appearing 20 Ma older (Whitehead et al., 1995).

153There is now little doubt on the ophiolitic nature of the Mont Albert (and associated Mont Paul and 154Mont Du Sud), mostly thanks to large-scale studies of ophiolites obducted during the Taconian 
155orogeny showing clear consistency both in terms of petrography and ages along the north-eastern 156Appalachians (e.g. Whitehead et al., 1995; Pincivy et al., 2003; Malo et al., 2008; De Souza et al., 1572012; Tremblay and Pinet, 2016). Tremblay and Pinet (2016, and references therein) advocate genesis 158of these ophiolites within a supra-subduction zone environment - with already-established plate 159convergence - based on extensive evidence of subduction of the Laurentian margin prior and during 160ophiolite formation. Similarly, the metamorphic sole is now interpreted as formed in a process 161equivalent to that of the Semail ophiolite and other soles worldwide, as discussed at length by Agard et 162al. (2016).

\section{NATURE, STRUCTURE AND DEFORMATION OF THE SOLE}

164The Mont Albert, Mont Paul and Mont du Sud are characterised by alpine tundra and rare krummholz 165on the peridotite (studied by e.g. Sirois and Grandtner, 1992; Martin and Germain, 2016) contrasting 166with the generally dense forest cover found over most of the amphibolite du diable. Exposure of the 167metamorphic sole is further restrained by the presence of numerous boulders of both local and remote 168origin related to the last glacial maximum (see Olejczyk and Gray, 2007). Consequently, exposed 169sections through the metamorphic sole are not continuous over scales of hundreds of metres as in 170Oman, complicating the study of mineralogical changes with distance to the contact of the peridotite, 171as folding and possible late faulting cannot be rigorously evaluated. The Mont Albert ophiolitic 172complex has nevertheless been mapped in detail and shows a simple structure, with the peridotite 173monotonously overlying the metamorphic sole, and mappable metamorphic grades within the sole 174(Fig. 2b-c).

175The overall structure of the Mont Albert is a large syncline with fold axis around $240^{\circ}$ (e.g. 176MacGregor and Basu, 1979; Gagnon and Jamieson, 1986). Exposure of the sole is best on the northern 177part of the massif, where foliation is parallel to the contact and dips steeply to the south in the range $17850-70^{\circ}$. In order to show a representative section through the metamorphic sole of the Mont Albert 179ophiolitic complex, a schematic log based on several small-scale sections is provided in figure 3a with 180field photographs (Fig. 3b-l). Late small-scale normal faulting on the north-east ridge of the massif, 181related to the 'Marches du Géant' fault system (Malo et al., 2008), only allows for approximate 182evaluation of the structural distance of metamorphic sole outcrops to the contact with the peridotite. 
183The following general description starts from the structural summit of the ophiolitic complex, going 184downwards, with distances expressed as the apparent structural distance to the contact.

\subsection{Structure and mineralogy of the peridotite}

186The peridotite is typified by harzburgite with earth yellow to brass colour due to weathering (Fig. 3b187c-d-e). 49 samples have been collected and studied for their mineralogy, which will be detailed 188elsewhere.

189Serpentinisation is pervasive, altering the rock density on various degrees. The base of the peridotite is 190mapped as a $\sim 20$ m-thick serpentinite layer (Fig. $3 \mathrm{~d}$ ) where serpentinisation is generally intense and 191accompanied by minor chalcedony. This serpentinite layer is not regarded as representative of the 192entire part of the sole with peridotite origin (part of red rectangle in the mantle wedge in Fig. 1c) first 193because contacts between this layer and the less serpentinised peridotite are only clear on the north194eastern part of the massif, then due to the fact that porphyroclastic peridotite is dominant hundreds of 195metres away from the contact, as observed by MacGregor (1979, using whole texture and chromian 196spinel as a strain indicator insensitive to serpentinisation). Therefore the extent of the deformed 197peridotite section of the sole into the mantle sequence is unclear. Away from this serpentinite layer, 198serpentinisation remains important irrespective of the distance from the contact with the amphibolite 199metamorphic sole. Grain size varies wildly from cm-scale orthopyroxene forming positive relief 200alteration to micrometric crystals in peridotite with ultramylonitic texture (see also Laurent and 201Hebert, 1979; MacGregor, 1979). Dunite and minor amphibole-bearing lherzolite and websterite are 202found inter-layered with the harzburgite. In thin section, amphibole (consisting of pargasite, Mg203hornblende and tremolite) appears of metamorphic origin linked to deformation stages in mylonites, 204together with secondary olivine, aluminous spinel and clinopyroxene. Metre-thick chromitite lenses 205with aspect ratio around 10 are sporadically found along the axial plane of the syncline with associated 206kammererite (mauvish pink Cr-Mg-chlorite, as reported by MacGregor and Basu, 1979). Penninite 207(Mg-chlorite with Si content greater than that of clinochlore) is frequently found all over the massif in 208haloes around chromian spinel. The main foliation in the peridotite is highlighted by serpentine-rich 209planes and clearly parallel to the contact with the metamorphic sole when observed on the northern 
210part of the massif (Fig. 3e, also Gagnon and Jamieson, 1986). Outcrops on the south-west part of the 211massif (near lake Isabelle) are obscured by intense serpentinisation and provide only poor exposure of 212the base of the peridotite.

214The high-grade unit of the amphibolite du diable is found underlying the peridotite (Fig. 3b-e-f-g). It is 215a heterogeneous but generally massive, dark, mafic metamorphic rock with well-defined foliation but 216without clear evidence for simple shear deformation. Lineation was only found for late amphibole. 217The maximum thickness of this unit is estimated in the range 80-100 m. Metamorphic grade decreases 218away from the contact. The term amphibolite to describe rocks immediately below the contact is 219somewhat abusive as amphibole content may be as low as $30 \%$, with more abundant garnet220clinopyroxene assemblage in varying relative amounts and minor plagioclase (1-5\%). Orthopyroxene 221was not observed. Grains are generally millimetre-sized $(1-5 \mathrm{~mm})$ with garnet occasionally reaching 1 $222 \mathrm{~cm}$. Away from the contact, the amphibole and plagioclase content increases (apparently gradually) at 223the expense of garnet and clinopyroxene, which disappear from mafic rocks about $15 \mathrm{~m}$ (for garnet) 224and $25 \mathrm{~m}$ (for clinopyroxene) away from the contact. Garnet amphibolite is also found $250 \mathrm{~m}$ from 225the contact on the north-eastern flank of Mont Olivine, in rocks that are apparently large $(>10 \mathrm{~m})$ 226boulders with no connection to the bedrock. Grain size decreases away from the contact to 227approximate $0.5 \mathrm{~mm}$ in the garnet-absent amphibolite. Epidote is ubiquitous as a retrogression phase, 228rimming clinopyroxene and amphibole, and as individual crystals, in varying amounts ( $<1$ to $10 \%)$. 229Garnet-rich layers (Fig. 3g) and iron oxide-rich layers are found alternating with the garnet230clinopyroxene mafic rocks close to the contact. The iron oxide-rich layers contain abundant chlorite, 231mica and epidote. Corundum is observed in some of these layers $<10 \mathrm{~m}$ away from the contact.

232About $35 \mathrm{~m}$ away from the contact, an intriguing pinkish $1.5 \mathrm{~m}$-thick quartz-plagioclase-amphibole233biotite-sphene-garnet layer with retrogressed pegmatitic texture is found cutting the foliation at a low 234angle (Fig. 3h). Of seemingly magmatic origin, it probably corresponds to the outcrop described and 235interpreted by Gagnon and Jamieson (1986) as a dyke injected after the metamorphic sole developed 236its foliation. Due to its orientation with respect to the foliation, we prefer referring to this as a sill. It is 
237heavily retrogressed with epidote on its margins co-existing with white and dark mica, and fibro-radial 238gedrite.

239Rare biotite-rich layers are found within $20 \mathrm{~m}$ from the contact. The first clear occurrences of 240aluminous metapelites appear about $25 \mathrm{~m}$ away from the contact as alternating dark red and pale grey 241layers ranging between 2 and $20 \mathrm{~cm}$ in thickness within the mafic rocks (metapelites are more easily 242identified in fallen boulders on the flanks of the north-east arête of the Mont Albert and on the north 243path to the summit just before the final ascent). These metapelites contain biotite (in greater 244proportions in the dark red layers), quartz, plagioclase, garnet, sillimanite, staurolite and muscovite as 245described below in greater detail, with scapolite, Fe-Ti oxides, epidote and chlorite in varying but 246generally minor proportions. Further away from the contact (45-55 m, Fig. 3i), pelitic schists contain 247kyanite with abundant mm-sized garnet, biotite, quartz, plagioclase, epidote and late muscovite.

248The low-grade unit of the metamorphic sole (Fig. 3j-l) is typified by metabasalt with "inverted" 249metamorphic grade within the upper greenschist to amphibolite facies. A section with good exposure 250is found on the shore of the Cascapedia river towards Mont du Sud; other interesting outcrops include 251the shore of the lake on top of 'ruisseau du Plaque Malade', the base of the north-east arête of Mont 252Albert (corresponding to the fourth zone described by Gagnon and Jamieson, 1986) and the path south 253of Lac du Diable (where O'Beirne-Ryan et al., 1990, reported sporadic migmatites, which were not 254confidently identified in this study). The difference between the base of the high-grade unit and the top 255of the low-grade unit is not clear-cut in terms of metamorphic grade. However these units differ in 256terms of strain and retrogression. The lower unit is variably spilitized (see e.g. Skelton et al., 2010 for 257comparison) and shows shearing and boudinage of former pillow-lavas (Fig 3j-k) together with 258ubiquitous recumbent folding highlighted by feldspar-rich layers (felsic amphibolite of Gagnon and 259Jamieson, 1986). In addition to green amphibole, albite, epidote and chlorite are present. The top of 260the unit is rich in iron oxide, the base contains pyrite up to 2 mm-large.

261Metasediments in the low-grade unit appear mainly as quartzite, in proportion of $5-10 \%$ of the sole 262thickness. White mica, chlorite and rare garnet have been found disseminated in the quartzite and in 263cm-thick beds. 
265

\begin{tabular}{|c|c|c|c|c|}
\hline Rock type & Main unit & Main minerals (>5\%) & Minor minerals ( $\leq 5 \%)$ & Accidental minerals $(<1 \%)$ \\
\hline amphibolite & high grade & Amp, Pl, Cpx & Grt, Opq, Ep, Rt & Ser, alt. $\varphi$ \\
\hline metasomatic rocks & high grade & Ep, Chl, Opq & Crn, Mrg, Pg, Rt & Qz, Ms, Spn \\
\hline amphibolite & low grade & Amp, Qz, Ep, Chl & Cal, Fsp & Opq, Сср \\
\hline quartzite & low grade & Qz, Pl, Bt, Ep & Chl & \\
\hline amphibolite & low grade & Amp, Qz, Ep, Pl & Opq & \\
\hline amphibolite & low grade & Amp, Ep, Pl, Opq & Qz & Cc, Spn \\
\hline amphibolite & low grade & Amp, Pl, Ep, Chl & Qz, Opq & Cc \\
\hline amphibolite & low grade & Amp, Ep, Opq & Qz & Cc, Spn \\
\hline schistose layer in quartzite & low grade & Amp, Qz, Pl, Ep, Chl & Opq & Spn \\
\hline schistose layer in quartzite & low grade & Phg, Qz, Opq, Chl, Amp & Grt, Ep & Сc \\
\hline amphibolite & low grade & Amp, Ep, Pl, Qz & Opq & \\
\hline amphibolite & low grade & Amp, Ep, Qz & Pl, Cc, Opq & \\
\hline amphibolite & high grade & Amp, Сpx, Ep, Opq & $\mathrm{Pl}$ & Fsp \\
\hline amphibolite & high grade & Grt, Amp, Cpx, Ep & Pl, alt. $\varphi$ & Ccp, Cv \\
\hline amphibolite & high grade & Amp, Сpx, Ep, Opq & alt. $\varphi$ & \\
\hline amphibolite & high grade & Cpx, Grt, Amp, Еp & Pl, alt. $\varphi$ & Qz \\
\hline
\end{tabular}




\begin{tabular}{|c|c|c|c|c|}
\hline amphibolite with garnet layer & high grade & Grt, Amp, Cpx, Ep & & \\
\hline amphibolite & high grade & Amp, Cpx, Pl, Ep & alt. $\varphi$ & Mrg \\
\hline amphibolite & intermediate & Amp, Cpx, Pl, Ep, Mrg & Ser, alt. $\varphi$ & Ccp, Cv \\
\hline Sill / metasediment contact & high grade & Fsp, Qz, Chl, Amp & Ms, Bt, Grt, Opq & Ep, Aln, Spn \\
\hline metapelite & high grade & Ab, Qz, Chl, Ep, Grt, Opq & Ms, Ap, Bt & Mnz \\
\hline metapelite & high grade & Qz, Grt, Phg, Bt & St, Opq, Ky, Pl & Rt, Chl \\
\hline metapelite & high grade & Qz, Ms, Bt, Grt, Pl, Ky & Opq, Ep & Chl \\
\hline sill & high grade & Ab, Amp, Spn, Opq & Ep, Ms & Mnz \\
\hline metapelite & high grade & Bt, Qz, Ep, Grt & Pl, Opq & Chl, Zrn \\
\hline metapelite & high grade & Qz, Pl, Grt, Phg & Bt, Spn, Ep & Rt, Chl \\
\hline metapelite & high grade & Phg, Grt, Qz, Pl & Bt, Spn, Ky & Amp, Chl, Ap \\
\hline metapelite & high grade & Grt, Bt, Pl, Sil, Opq & St, Phg, Scp & \\
\hline
\end{tabular}

266Table 1. Mineralogy of samples used in this article. Main minerals are sorted from more to less abundant. Alt. $\varphi$ : minute alteration phases replacing plagio-

267clase (Ms, Mrg, Ntr, Ep etc., see Fig. 4). 


\section{PETROGRAPHY AND MINERALOGY}

270In this section, the textural relationships between minerals are presented with microphotographs and 271SEM images, separating metabasalts from rocks with sedimentary protoliths. The 'sill' (Fig. 3h) and 272oxide-rich layers are presented with the non-mafic metamorphic rocks. The mineralogy is summarized 273in table 1. All abbreviations in figures, tables and appendix are after Whitney and Evans (2010).

\section{4.1. Sampling and analytical techniques}

275104 samples have been collected on the Mont Albert and Mont du Sud massifs. Only samples from the 276metamorphic sole are presented here (using 29 samples selected out of the 55 metamorphic rocks 277collected). Scanning electron microscopy (SEM) was used after optical microscopy at ISTeP 278(Sorbonne Université, Paris, France) using a Zeiss Supra 55VP apparatus associated to a SSD detector 279PTG Sahara for imaging and elemental mapping in energy-dispersive spectroscopy mode. 280Electron probe micro-analyses were carried out at CAMPARIS (Sorbonne Université, Paris, France) 281with both Cameca SX-5 and SX-100 instruments. Point measurements were made in classical 282analytical conditions (15 kV acceleration voltage and $10 \mathrm{nA}$ beam current allowing 2 $\mu \mathrm{m}$ beam size in 283wavelength-dispersive spectroscopy mode) using diopside (Ca, $\mathrm{Mg}, \mathrm{Si}$ ), $\mathrm{MnTiO}_{3}(\mathrm{Mn}, \mathrm{Ti})$, orthoclase 284(K, Al), $\mathrm{Fe}_{2} \mathrm{O}_{3}(\mathrm{Fe})$, albite $(\mathrm{Na})$ and $\mathrm{Cr}_{2} \mathrm{O}_{3}(\mathrm{Cr})$ as standards for calibration of elements indicated in 285parentheses. Elemental mapping has been carried out with identical voltage and either $10 \mathrm{nA}$ current 286and counting time of $300 \mathrm{~ms}$ per point or with increased current (100 nA) and counting time of $100 \mathrm{~ms}$ 287per point. Analyses were calibrated with the manufacturer's software using standards as for point 288analyses, and it was ensured that results of mapping were consistent with point measurements.

\subsection{Mafic rocks}

$$
\text { 4.2.1. High grade unit }
$$

291At the thin-section scale, rocks sampled at the contact with the peridotite show porphyroblastic texture 292(Fig. 4a) with garnet, pale green clinopyroxene, deep green amphibole crystals aligned within the 293foliation, plagioclase and epidote. Garnet is typically millimetre-sized and disseminated throughout 294samples (Fig. 4b) or in garnet-rich layers (Fig. 3g). Quartz inclusions are rarely ( $\sim 5 \%$ ) found in garnet 295porphyroblasts. Clinopyroxene appears as large $(>5 \mathrm{~mm})$ crystals with undulose extinction, and in 
296small (100-500 $\mu \mathrm{m})$ optically homogeneous crystals. Clinopyroxene is found disseminated in the rock 297and in cm-thick bands (Fig. 4b) parallel to the amphibole foliation and showing both types of crystals. 298Several types of symplectite are found throughout the samples, involving garnet, clinopyroxene, 299amphibole, plagioclase, oxides and epidote, with all six phases or a combination of some of them. 300Clinopyroxene-amphibole symplectite with and without plagioclase (Fig. 4f) is observed wherever 301clinopyroxene is stable. Epidote-amphibole symplectite is seen in some rocks less than $10 \mathrm{~m}$ away 302from the contact. Garnet-clinopyroxene symplectite with plagioclase or with epidote and oxides (Fig. $3034 \mathrm{f}$ and g), both usually with retrogressive mica, are found in garnet-bearing samples regardless of the 304distance to the contact. Plagioclase in the symplectite is rarely preserved. It is usually replaced by fine 305intergrowths of epidote and muscovite (Fig. 4 h-i). Under the optical microscope, these intergrowths 306appear as a dark, turbid phase (Fig. 4d-e-g) with second order birefringence tentatively identified as 307diaspore by O'Beirne-Ryan et al. (1990). In this study diaspore has not been found in these 308intergrowths, instead margarite, albite, adularia and natrolite appear as frequent alteration products of 309the (previously-retrogressed?) plagioclase (Fig. 4 h-i). Chalcopyrite is found sporadically throughout 310retrogression assemblages, accidentally with covellite. Translucent epidote crystals are frequently 311associated with retrogressed plagioclase, and late yellow epidote cross-cuts most samples, chiefly 312along the foliation and less frequently at a sharp angle with it. This leads to compositional banding on 313the scale of centimetres in some samples, as noted by O'Beirne-Ryan et al. (1990). In the 314clinopyroxene-free zone, pale yellow epidote is aligned with the amphibole (Fig. 4h) and makes up to $31540 \%$ of the sample. Large amphibole crystals are often zoned, with pale green cores and darker rims 316(Fig. 4a).

\section{$317 \quad$ 4.2.2. Low grade unit}

318Strain is marked by folding in the low-grade part of the metamorphic sole. The top of this unit is 319characterized by elongated, 100 $\mu$ m-long amphibole showing a well-marked foliation, sometimes 320with crenulation (Fig. 5b). However crystal size may be larger with amphibole reaching $3 \mathrm{~mm}$ in some 321samples. Albite is ubiquitous and makes up to $50 \%$ of some samples. Sphene, chlorite, hematite and 322ilmenite are observed in almost all samples. Orthoclase has been found in samples on the south end of 323the section along the Cascapedia river. Calcite-filled spherulites with epidote rims (Fig. 5c) are 
324interpreted as former vesicles (see e.g. Schiffman and Staudigel, 1995). These are increasingly found 325downwards in the metamorphic sole and show evidence of shearing. Amphibole is more 326heterogeneous downwards, with pale green cores and darker blue-green rims (Fig. 5a). Symplectites 327are not observed.

\subsection{Metasediments and non-mafic rocks}

329Sillimanite-bearing metapelites (closest to the contact, Fig. 6f-g-h) have well-developed schistosity 330marked by biotite. Euhedral to sub-euhedral mm-sized garnet is found co-existing with prismatic 331sillimanite and well-preserved plagioclase including sillimanite needles (Fig. 6f). Garnet hosts 332numerous inclusions: biotite $(\sim 300 \mu \mathrm{m})$, oxides, staurolite, plagioclase, apatite, sillimanite (Fig. 6h) 333and abundant negative crystal shape inclusions resembling peritectic silicate melt inclusions found in 334migmatites and granulites (nanogranites, see Fig. 6h-i and Cesare et al., 2015). Titano-ilmenite is 335found in infrequent but large (cm-sized) crystals around garnet and plagioclase, it shows generalized 336exsolution. Scapolite appears in large $(\sim 1 \mathrm{~cm})$ poikilitic crystals. Staurolite is found both in the 337foliation and cutting the foliation, including titano-ilmenite and plagioclase (Fig. 6f-g). Staurolite in 338contact with plagioclase and sillimanite is often euhedral with some faces resorbed. The staurolite at 339an angle with the foliation is locally observed growing on garnet. Muscovite is present as a late phase 340at sharp angle with the foliation.

341Red oxide-rich layers apparently associated with metasediments in the field contain corundum, epidote 342and abundant Fe-Ti oxides (Fig. 6d-e). Corundum appears dark blue in thin section due to numerous 343minute rutile inclusions. It is haloed by margarite, paragonite and diaspore, associated with chlorite, all 344cross-cutting the foliation marked by epidote and corundum. These assemblages and their 345retrogression have already been mentioned in gneissic metabasalts in contact with peridotite (Bucher 346et al., 2005 ; Operta et al., 2003; Pratt, 1906) and interpreted as the product of fluid-rock interactions 347and metasomatism of metasediments in contact with ultramafic rocks.

348Minerals in the 'sill’ $35 \mathrm{~m}$ away from the contact (§ 3.3; Fig. 3h) are strongly retrogressed (Fig. 6d), 349with little textural evidence preserved. The apparent foliation is defined by amphibole and biotite. 350Some amphibole crystals are also oriented within shear bands filled with euhedral iron oxide. Quartz 351shows undulose extinction. Plagioclase is sericitised. Epidote veins cross-cut the sample. Biotite is 
352mostly replaced by chlorite, and muscovite grains are again oriented perpendicular to the foliation. 353Garnet crystals are more abundant on the margins and contain quartz and Fe-Ti-oxides inclusions. 354Neither kyanite nor sillimanite was observed.

355Kyanite-bearing schists shown in figures $3 \mathrm{i}$ and 6a-c, sampled $\sim 50 \mathrm{~m}$ away from the contact, contain 5 356mm-large garnet, quartz, biotite, plagioclase, muscovite, apatite, rutile, epidote and late chlorite 357growing after biotite. Sillimanite, fibrolite and nanogranite-like inclusions have not been confidently 358identified in these samples. Staurolite is only found included in garnet (Fig. 6c), together with 359muscovite, apatite and biotite. Accidental $30 \mu \mathrm{m}$ monazite has been found.

360In the deformed low-grade unit of the metamorphic sole, chlorite-mica-bearing quartzites show a well361developed foliation with oriented phyllosilicates. Crenulation cleavage is observed in all samples. 362Garnet is rare (5\%, in one sample) and includes apatite and chlorite. Albite is found disseminated in 363thin sections, with calcite and epidote. Muscovite and chlorite are intergrown, with minor biotite. 364These are generally smaller than $20 \mu \mathrm{m}$.

\section{MINERAL COMPOSITION}

366Representative electron probe micro-analyses are provided in tables in appendix for amphibole (A1), 367clinopyroxene (A2), plagioclase (A3), micas (A4), epidote (A5), garnet (A6) and accessory phases 368(A7, including staurolite, chlorite, margarite, scapolite and pumpellyite).

\section{5.1. Mafic rocks}

370Garnet in high-grade mafic rocks is a solid solution with $40-60 \%$ almandine, $12-30 \%$ pyrope, 18-45\% 371grossular and minor spessartine content $(\leq 7 \%)$. Garnet zoning is bimodal, with homogeneous cores 372and spessartine - almandine-rich rims, best seen on the Mn map content (Fig. 7a-c). Mn-enriched 373zones correspond to the garnet rim with symplectic texture, crystallising with plagioclase and 374clinopyroxene. It is noteworthy that symplectic garnet is found surrounding homogeneous Mn-poor 375garnet. Mn enrichment is systematic around garnet cores and followed by Mn depletion in largest 376symplectites (Fig. 7c). The systematic pattern implies that garnet rims with symplectite texture were 377produced, not consumed, during symplectite growth, in contrast with kelyphite usually associated to 378garnet consumption during retrogressive decompression (Messiga and Bettini, 1990). In this view, Mn 379depletion is a reservoir effect during symplectite growth (as for classical Mn bell-shaped zoning in 
380garnet) not necessarily related to changing pressure-temperature conditions (e.g. Kohn, 2003; Tropper 381and Recheis, 2003).

382Clinopyroxene (Fig. 7c-d-e) is of diopside type with $X_{\mathrm{Mg}}$ (defined as $\mathrm{Mg} /\left(\mathrm{Mg}+\mathrm{Fe}^{2+}\right) \mathrm{pfu}$ ) in the range 3830.6-0.8, Na content between 0.04 and 0.06 apfu, and $\mathrm{Al}$ content between 0.10 and 0.35 apfu. Samples 384closest to the contact have varying $X_{\mathrm{Mg}}$ (from 0.60 to 0.75 ) and highest jadeite content (sample MA38514-35, 2 metres off the contact). Further away from the contact, large clinopyroxene crystals within 386the foliation have lowest $\mathrm{Al}$. Al is high in small pyroxene crystals and in crystal cores, and low in the 387pyroxene with symplectite texture (Fig. 7b and 8d). $X_{\mathrm{Mg}}$ increases with decreasing $\mathrm{Al}$ content.

388Figure 9 shows the compositional variation of amphibole in high and low-grade mafic units. 389Amphibole close to the contact shows compositional zoning between ferroan pargasite and 390tschermakitic hornblende (both sampled 5-8 m away of the contact) using the definition and site 391repartition of Leake et al. (1997). Corresponding Ti content reaches 0.20 apfu for the pargasite and 392decreases steadily with increasing Si content towards Ti-free actinolite. Amphibole in the low-grade 393unit is often zoned, with Al-poor cores and Al-rich rims (corresponding to Si-rich, Ti-poor cores and 394Si 6.5, Ti 0.05 apfu rims, see Fig. 9a-b-c), consistently with colour variations marked by paler cores. 395Feldspars mainly consist of plagioclase, orthoclase (or adularia) and albite (Fig. 9d). Extensive 396retrogression of plagioclase in the garnet-clinopyroxene symplectite complicates EPMA 397measurements and prevents studying zoning. Anorthite content in plagioclase ranges between 75 and $39892 \%$ in the high-grade section with garnet and clinopyroxene. Further away from the contact and in 399the low-grade section, plagioclase is of oligoclase type with anorthite content in the range $17-30 \%$. 400Albite, orthoclase and adularia are found in samples from the low-grade unit and unequivocally 401associated to retrogression. Interstitial sanidine with complex twinning around $\sim 40 \%$ orthoclase (Fig. 4029d) was accidentally found in samples where plagioclase content is low ( $<5 \%$, samples MA-14-22 and 403MA-14-34).

404Epidote (Fig. 10) is a solid solution varying from a clinozoisite-rich component (maximum $\mathrm{Al}$ content $405=2.87$ apfu found in our samples) to a pistacite-rich component $\left(\mathrm{Fe}^{3+}=1 \mathrm{apfu}\right)$. The more aluminous 406compositions are restricted to the high-grade section of the metamorphic sole, and ferric epidote is 407observed in almost all mafic samples regardless of metamorphic grade, as individual crystals, 
408overgrowths and in veinlets cross-cutting the foliation (Fig. 10b-c). In high-grade rocks, Al-rich 409epidote is observed associated to retrogressed plagioclase (Fig. 7d), corundum-rich layers and with the 410garnet-clinopyroxene-amphibole symplectite. Allanite is sporadically found in low-grade mafics with 411ferric epidote overgrowths.

412Chlorite is of chamosite type (mostly tri-trioctahedral with octahedral sum greater than 5.90) and has $413 X_{\mathrm{Mg}}$ between 0.55 and 0.70 , with highest values reached in corundum-epidote-bearing samples close to 414the contact and lowest $X_{\mathrm{Mg}}$ in the low-grade section of the sole. Only sample MA-14-22 shows zoning, 415with crystal cores at $\mathrm{Si}=3.0 \mathrm{apfu}$ and edges/rims at $\mathrm{Si}=2.7$ apfu. Other samples have $\mathrm{Si}$ content in 416the range 2.55-2.74 with little variations within sample.

\section{5.2. Metasediments and "intrusion"}

418Figure 11 presents mineral compositions for garnet, biotite, feldspar and phengite for the metapelites 419and metacherts found in the metamorphic sole of Mont Albert.

420Garnet in metapelites from the high-grade section is a solid solution between almandine (55-80\%), 421grossular (5-25\%), pyrope (10-25\%) and minor spessartine component $(<7 \%)$. Zoning is ubiquitous 422with concentric, oscillatory and fracture-sealing zoning best observed in Mn and Ca (Fig. 11 b,c). Ca423rich core in some garnet (Fig. 11b) is mantled by Ca-poor areas. Rims are Ca-rich and show partial 424resorption. Mn first increases in Ca-rich rims and decreases again in the external, Ca-richest parts of 425the rims. More classical concentric zoning with Mn-rich core and Ca-rich rims is also observed (Fig. 42611c), also with limited resorption. Garnet from the lower-grade section (found in veinlets in 427metacherts along the Cascapedia river, samples MA-14-24 and MA-14-31 on Fig. 11a) has higher 428pyrope (sample MA-14-31) and grossular (sample MA-14-24) content.

429Biotite has $X_{\mathrm{Mg}}$ in the range 0.45-0.65, with highest Ti content associated with $X_{\mathrm{Mg}} \sim 0.55$ (Fig. 11d). 430Feldspars consist of orthoclase and plagioclase varying between oligoclase and andesine (Fig. 11e). 431Phengite is generally muscovite-rich (Fig. 11f) with up to $18 \%$ Tschermak substitution towards 432celadonite and limited pyrophyllitic substitution ( $\leq 6 \%$ for most analyses).

433Staurolite composition shows negligible solid solution with $\mathrm{Mn}\left(\leq 0.2 \mathrm{MnO}\right.$ wt. \%) and has $X_{\mathrm{Mg}}$ in the 434range 0.15-0.25, for crystals included in garnet as well as in the foliation. Staurolite at an angle with 435the foliation (Fig. 6g) and growing over garnet is homogeneous around $X_{\mathrm{Mg}}=0.20$. 
436Scapolite is a sodian meionite with $\mathrm{Si}=7.17 \mathrm{apfu}$ and $\mathrm{Ca} /(\mathrm{Ca}+\mathrm{Na})=0.71$ when structural formula is 437calculated to compensate 50 negative charges ( $\mathrm{C}$ and $\mathrm{Cl}$ were not measured).

438As for mafic rocks, chlorite is a chamosite with low sudoite content. It has $X_{\mathrm{Mg}}$ between 0.39 and 0.52 , 439lower than for mafic rocks but similar Si content in the range 2.55-2.65 apfu.

\section{PHASE EQUILIBRIA AND THERMOBAROMETRY}

441The petrological evolution of the sole is modelled here with the use of a pseudosection (phase diagram 442for fixed bulk rock composition) representative of the mafic rocks. Despite progress in the 443thermodynamic models for mafic compositions, uncertainties remain large for thermobarometry on 444these rocks, especially compared to mineral assemblages in metapelites. To further constrain 445conditions of crystallisation, we carried out empirical thermobarometry on all lithologies and multi446equilibrium thermobarometry on selected assemblages in metapelites. This approach has been 447preferred over building pseudo-sections as the observed metapelites are very thin beds (up to $10 \mathrm{~cm}$ 448thick within the mafic rocks) showing poly-metamorphic history with compositional banding, 449retrogression and evidence for opening of the system and interaction with the mafic rocks. Therefore 450assuming equilibrium at sample scale and close system has been deemed erroneous for the 451metapelites.

\section{6.1. Mafic rocks}

\section{$453 \quad$ 6.1.1.Phase equilibria}

454Figure 11 shows a pseudo-section modelled in the NCKFMASHTO system for the high-grade subunit, 455using THERMOCALC version 3.45 (Holland and Powell, 1998, 2011) with the updated database 456version (tc-ds62) of Holland and Powell (2011). The selected bulk rock composition is an average of 457six samples of the garnet amphibolite measured by O’Beirne-Ryan et al. (1990), which has been 458deemed representative of the large-scale composition of the high-grade subunit, reducing sampling 459biases due to compositional banding. Water content was calculated through mass balance of 460amphibole proportion over several thin sections and corresponds within error to the average loss on 461ignition obtained by O’Beirne-Ryan et al. (1990). Activity models are after White et al. (2014b) for 462orthopyroxene, biotite, chlorite and garnet, Green et al. (2016) for mafic melts, augite and hornblende, 463Holland and Powell (2003) for plagioclase and K-feldspar, and White et al. (2000) for ilmenite- 
464hematite. In the absence of magnetite or any other $\mathrm{Fe}^{3+}$ rich phase at peak conditions, rock oxidation 465was set to $1 \%$, following previous studies on similar rocks (e.g., Guilmette et al., 2011; Palin et al., 4662014).

467Peak conditions were approximated based on the observed mineralogy and isopleths for garnet 468(grossular fraction and $X_{\mathrm{Fe}}=\mathrm{Fe} /(\mathrm{Mg}+\mathrm{Fe})$, all in apfu), clinopyroxene $\left(X_{\mathrm{Fe}}\right)$, and amphibole $\left(X_{\mathrm{Fe}}\right)$, using 469representative mineral compositions for the large, homogeneous crystal cores (not the symplectites) 470given by O’Beirne-Ryan et al. (1990) and measured in this study. Garnet, clinopyroxene and 471amphibole are stable throughout the pseudosection, with the amphibole-out reaction at temperatures 472greater than $1000^{\circ} \mathrm{C}$, which is consistent with the dehydration reaction of hornblende (Wolf and 473Wyllie, 1994). Pressure-temperature conditions for the field best matching the mineralogy for the 474high-grade subunit are around $0.98 \pm 0.04 \mathrm{GPa}$ and $825 \pm 25^{\circ} \mathrm{C}$ (Fig. 12). They lie at supra-solidus 475conditions where rutile is stable. Plagioclase is not predicted at peak conditions, also consistently with 476observations where plagioclase is only very rarely found other than associated to the symplectites. In 477this pseudosection, the plagioclase field does not extend to pressures above $0.8 \mathrm{GPa}$. Estimated modes 478are in good agreement with sample modes for amphibole (44\%), clinopyroxene (20\%) and garnet (26 479\%), as for sample MA-14-35 (Fig. 4b). A melt proportion of 9 vol.\% is predicted and broadly 480consistent with previous estimates for mafic rocks at comparable conditions using similar activity 481models (Palin et al., 2016 ; Soret et al., 2017). The Ti content of amphibole (0.08 apfu) is close to that 482reported by O’Beirne-Ryan et al. (1990) (0.10 apfu), but in the low range of values document in this 483study (0.05 up to 0.20 apfu; Fig. 9b). The $X_{\mathrm{Fe}}$ of amphibole at $\sim 0.32$ compares well with the 484compositions observed here and given by O’Beirne-Ryan et al. (1990).

\subsubsection{Garnet-clinopyroxene thermometry}

486Garnet-clinopyroxene thermometry has been carried out on the two samples (MA-14-35 and MA-1448738) where phase relations between garnet and clinopyroxene are clearest. In both cases garnet and 488clinopyroxene are zoned, with relatively large, homogenous cores and variably-sized rims linked to 489the garnet-clinopyroxene-epidote-plagioclase symplectite. Equilibrium is inferred between garnet and 490clinopyroxene cores, and between minerals in the symplectitic rim. The Fe-Mg distribution coefficient 
$491\left(K_{D}=\frac{\mathrm{Fe}_{\mathrm{Grt}}^{2+} \cdot \mathrm{Mg}_{\mathrm{Cpx}}^{\square}}{\mathrm{Fe}_{\mathrm{Cpx}}^{2+} \cdot \mathrm{Mg}_{\mathrm{Grt}}^{\square}}\right)$ increases from core pairs (in the range $K_{D}=3.5$ - 5) to rim pairs $\left(K_{D} \geq 7\right)$. Figure 49213 shows the results of four empirical thermometers. The first three (Ellis and Green, 1979; Powell, 4931985; Krogh Ravna, 1988) give consistently higher temperatures than the more recent thermometer of 494Krogh Ravna (2000) which is retained, as it specifically addresses possible over-estimation by the 495other three thermometers in this type of samples. Selected crystallisation temperatures vary between 496820 and $900^{\circ} \mathrm{C}$ for equilibrium between garnet-clinopyroxene cores and between 680 and $720^{\circ} \mathrm{C}$ for 497equilibrium between rims.

\section{$498 \quad$ 6.1.3.Amphibole-plagioclase thermometry}

499The amphibole-plagioclase thermometer of Holland and Blundy (1994) has been used on two samples 500(MA-14-38, MA-14-42) from the high-grade amphibolite and four samples (MA-14-22, 23, 26, 32) 501from the amphibolite of the low-grade unit. For the high-grade unit, equilibrium is inferred between 502pargasitic amphibole and anorthitic plagioclase (Fig. 9). For the low-grade unit, equilibrium is inferred 503between amphibole rim composed of Mg-hornblende and plagioclase of andesine type with anorthite 504content of 23\% (Fig. 9). Pressure was assumed constant at 0.95 GPa. This method gave two clusters 505separated by $\sim 200^{\circ} \mathrm{C}$ : the high-grade amphibolite yielded estimates of $875 \pm 40^{\circ} \mathrm{C}$ and the low-grade 506amphibolite yielded estimates of $680 \pm 40^{\circ} \mathrm{C}$.

\subsection{Metapelites}

508Multi-equilibrium thermobarometry has been carried out on selected mineral assemblages in 509metapelites. Three main parageneses have been recognized and tested for thermodynamic equilibrium: 510 - kyanite - garnet cores - quartz - biotite - staurolite as seen in garnet inclusions (e.g. Fig. 6), for the 511prograde history

512 - aluminosilicate - garnet mantle - plagioclase - biotite - quartz with kyanite or sillimanite depending 513on sample, for peak metamorphic conditions

514 - sillimanite - staurolite - phengite, all crosscutting the foliation and associated in sample MA-15-5a 515(Fig. 6f-h).

516Multi-equilibrium thermobarometry was carried out using THERMOCALC (Holland and Powell, 5171998, 2011) version 3.33 with the thermodynamic database tc-ds55. Results are summarised in figure 
51814. For sample MA-15-5a, the peak mineral assemblage garnet + biotite + muscovite + plagioclase + 519 quartz + sillimanite gives estimates of $690 \pm 27^{\circ} \mathrm{C}$ and $0.85 \pm 0.1 \mathrm{GPa}$. For sample MA-14-50, the 520assemblage garnet + biotite + muscovite + plagioclase + quartz + kyanite yields conditions of $750 \pm$ $52130^{\circ} \mathrm{C}$ and $0.92 \pm 0.1 \mathrm{GPa}$. The same assemblage in sample MA-14-48a gives peak conditions of $615 \pm$ $52265^{\circ} \mathrm{C}$ and $1.2 \pm 0.4 \mathrm{GPa}$. For this sample, addition of staurolite (included in garnet with kyanite and 523biotite) refines estimates for prograde metamorphism at $633 \pm 32^{\circ} \mathrm{C}$ and $1.1 \pm 0.17 \mathrm{GPa}$. For the 524staurolite and aluminosilicate-free sample MA-14-52, the assemblage garnet + biotite + muscovite + 525plagioclase + quartz yields $640 \pm 40^{\circ} \mathrm{C}$ and $1.01 \pm 0.14 \mathrm{GPa}$.

526Chlorite-phengite thermobarometry could not be systematically carried out due to the generally low 527sudoite content of the chlorite, which nevertheless indicates that chlorite likely crystallised over $350^{\circ} \mathrm{C}$ 528(see Bourdelle and Cathelineau, 2015). Chlorite thermometry (using the approach and thermodynamic 529properties given in Vidal et al., 2006) yields values of $457^{\circ} \mathrm{C}$ and $496^{\circ} \mathrm{C}$ for two groups of chlorite in 530sample MA-14-22, a mafic rock in the low-grade section of the sole. Unfortunately no phengite at 531equilibrium were identified in this sample, therefore corresponding pressure could not be estimated.

532The Ti-in-biotite thermometer of Henry et al. (2005) yields estimates of $695 \pm 23^{\circ} \mathrm{C}$ and $680 \pm 23^{\circ} \mathrm{C}$ 533for the samples MA-15-5a and MA-14-50, respectively. The garnet-biotite thermometer of Holdaway 534 (2000) gives estimates of $700 \pm 25^{\circ} \mathrm{C}$ for these samples. Additional pressure estimates in metapelites 535were obtained using the garnet-biotite-muscovite-plagioclase barometers of Wu (2015), yielding $0.8 \pm$ 5360.12 GPa and $0.91 \pm 0.12 \mathrm{GPa}$ for samples MA-15-5a and MA-14-50. These are within uncertainties 537of the garnet-biotite-muscovite-aluminosilicate-quartz barometer of Wu and Zhao (2007), yielding 0.7 538 $\pm 0.08 \mathrm{GPa}$ and $0.88 \pm 0.08 \mathrm{GPa}$ for samples MA-15-5a and MA-14-50, not shown on figure 14 for 539readability.

540In the low-grade unit, the Ti-in-biotite thermometer gives $610 \pm 23^{\circ} \mathrm{C}$ for the sample MA-14-24 (the 541only biotite-bearing sample in this subunit). In sample MA-14-31, the Ti-in- muscovite thermometer 542of Wu and Chen (2015) yields $515 \pm 65^{\circ} \mathrm{C}$, within uncertainties of the garnet-muscovite thermometer 543of $\mathrm{Wu}$ and Zhao (2006) at $555 \pm 16^{\circ} \mathrm{C}$ on the same sample.

\section{DISCUSSION}

545 7.1. Petrological evolution of the metamorphic sole 
547Close to the contact with the peridotite, metamorphic sole rocks are strained, sheared and lack relicts 548of original magmatic minerals so that the original nature of the rock is hard to assess: although the 549high-grade unit is indisputably of mafic origin, whether these rocks were gabbros or basalt-type lavas 550could not be deciphered. The presence of metasediments in the high-grade unit advocates oceanic 551floor origin, and the persistence of (strained) boudins and spherulites in the folded, lower-grade unit 552suggests basaltic lavas with a shallow oceanic crust origin, together with the absence of relicts of 553gabbro-derived clinopyroxene. This is consistent with a single geodynamic origin for the metamorphic 554sole, with the metasedimentary content increasing away from the structural top (as discussed by Agard 555et al., 2016). In this view the metamorphic sole of the Mont Albert ophiolitic complex represents a 556subducted portion of the Schick-Schock group units, which is consistent with the similarities in 557compositions reported for both mafic lithologies (O'Beirne-Ryan et al., 1990; Camiré et al., 1995). 7.1.2. Pressure-temperature history of the samples

559Thermobarometric estimates carried out in this study are compiled in figure 14. For the high-grade 560unit, pressure estimates on metapelites cluster within uncertainties and indicate crystallisation 561pressures around 0.95(+/-0.10) GPa. Calculated temperatures range between $650^{\circ} \mathrm{C}$ and $950^{\circ} \mathrm{C}$, with 562garnet-clinopyroxene estimates using crystal cores being highest in sample MA-14-38 and seemingly 563somewhat overestimated. Broadly speaking, mafic samples close to the contact with peridotites have 564reached temperatures between 850 and $900^{\circ} \mathrm{C}$.

565Estimates at lower temperatures for these samples, such as garnet-clinopyroxene rims, are interpreted 566as indicative of cooling along the retrograde path. Metasediments were not found less than $\sim 25 \mathrm{~m}$ 567away from the contact and indicate lower temperatures in the range $750-650^{\circ} \mathrm{C}$, matching 568crystallisation of the garnet-clinopyroxene rims. Kyanite and staurolite inclusions in garnet show that 569prograde metamorphism took place in the field of kyanite and staurolite, along a geothermal gradient 570of the order of $20^{\circ} \mathrm{C} / \mathrm{km}$ (sample MA-14-52). For the lower-grade unit rocks, further away from the 571contact, estimated temperatures are distinctly lower than close to the contact, with some overlap with 572the lowest peak temperatures estimated in the high-range unit $\left(\sim 700^{\circ} \mathrm{C}\right)$. 
573In rocks from the lower-grade unit, equilibrium was probably not reached at sample scale at peak 574temperature, given that amphibole preserves Al-poor cores interpreted as crystallising along the 575prograde path. In these samples chlorite geothermometry gives temperatures below $500^{\circ} \mathrm{C}$ which are 576interpreted as crystallisation temperatures during cooling. Crystallisation pressures here are poorly 577constrained, apart from the lack of evidence of high-pressure or very-low pressure index minerals. 578Tectonic juxtaposition of the low- and high-grade units and peak metamorphic conditions of the low579grade unit suggest a retrograde path along a similar geothermal gradient for both units.

580These results are consistent with step-wise accretion of two (or more) subunits of metamorphic soles. 581These units (and/or samples within the subunits) do not share an identical pressure-temperature path, 582as suggested by Gagnon and Jamieson (1986). Metamorphic rocks close to the contact with the 583peridotites record higher temperatures than further away, either because of step-wise accretion of 584subunits or due to slow thermal equilibration compared with exhumation. The obtained pressure585temperature paths appear clockwise, with burial largely in the field of kyanite and exhumation starting 586in that of sillimanite.

\subsubsection{Compositional evolution and stability of epidote}

588The broad compositional range of epidote and its links with texture (with Al-rich cores and $\mathrm{Fe}^{3+}$-rich 589rims and late veins, Fig. 7 and 10), mineral assemblage and distance to the contact, allow further 590constraining the petrological history of the metamorphic sole. The composition of epidote is known to 591vary with temperature and oxygen fugacity $\left(\mathrm{fO}_{2}\right)$, where increasing $\mathrm{fO}_{2}$ leads to increase the stability 592field of epidote towards higher temperature (e.g. Holdaway, 1972). In metasomatic veinlets from the 593garnet-bearing amphibolite with epidote-corundum assemblage (sample MA-14-2b, Fig. 6d-e and 10), 594the pistacite component of epidote is about 0.5. This indicates a maximum crystallisation temperature 595around $700^{\circ} \mathrm{C}$ (Holdaway, 1972). Variations of composition in the high-grade subunit where the $\mathrm{Fe}^{3+}$ 596content of epidote increases at the expense of $\mathrm{Al}$ from crystal cores to rims (Fig. 7d) then to late veins 597(Fig. 10) are consistent with decreasing crystallisation temperatures as indicated by the clinozoisite 598component (Schmidt and Poli, 2004).

599The texture of clinozoisite-rich epidote and its association to garnet, clinopyroxene, plagioclase and 600oxide in the symplectite point to high-grade metamorphic conditions. The presence of clinozoisite-rich 
601epidote may reflect the involvement of magmatic fluids, as MORB melting gives epidote up to 800$602830^{\circ} \mathrm{C}$ at 0.9-1.2 GPa (see review of Schmidt and Poli, 2004) and magmatic epidote is also mentioned 603in comparable assemblages with similar texture by Lardeaux and Spalla (1991) and Nicollet et al. 604(1979). Higher temperature for epidote crystallisation in metamorphic soles is not impossible as $\mathrm{fO}_{2}$ 605and water content are only inferred here, and zoisite may have been missed in the field. The 606amphibole-epidote-plagioclase-garnet assemblage is nevertheless regarded as representative of 607conditions around $0.9-1.5 \mathrm{GPa}$ and $700-830^{\circ} \mathrm{C}$ for reasons given by Schmidt and Poli (2004), in good 608agreement with present thermobarometric estimates.

\section{7.2. Formation and structure of the metamorphic sole}

$610 \quad$ 7.2.1.Metamorphic sole and subduction initiation

611The metamorphic sole of the Mont Albert ophiolitic complex appears broadly similar to other 612metamorphic soles, hinting at a common formation process. The overall structure and petrology 613reproduce that of the Semail ophiolite, yet with smaller differences between metamorphic grades for 614the base of the high-grade unit and the top of the low-grade unit. However differences in deformation 615between high and low-grade units are as striking as in the Semail ophiolite, where the low-grade unit 616is thickened by numerous folds and faults (Hacker and Mosenfelder, 1996; Gray and Gregory, 2000). 617Here, aluminous metasediments allow more accurate estimation of peak metamorphic pressure, and 618confirm broadly similar peak conditions. Peak temperatures are in the range of those estimated in 619Semail $\left(\sim 850^{\circ} \mathrm{C}\right)$, and compare well with estimations for the sole of the Bay of Islands complex, where 620sillimanite is also reported (e.g., Suhr and Cawood, 1993). These estimates all fall well into stability 621conditions of a metabasalt-derived melt (Fig. 12). In the model of Agard et al. (2016), subducted 622metabasalts (future metamorphic soles) are "underplated” (accreted to upper plate peridotites) when 623both units have similar effective viscosities and coupling is maximal between the two. Agard et al. 624(2016) emphasize that conditions allowing accretion of the metamorphic sole are only transiently met, 625because of the general cooling of the subduction system. This restricts the origin of the high-grade 626section of the metamorphic sole to the tip of the forming slab (see Fig. 1a-b), and implies that the 627mixed mafic-sedimentary protolith deposited close to the future trench - and further away from the 
628continental margin than presented in e.g. the geodynamic reconstruction of Tremblay and Pinet (2016, 629their figure 19).

630Figure 15 compares peak metamorphic conditions estimated in this study to the thermal structure of 631oceanic lithosphere over time, from present-time modelling. Peak metamorphic conditions of 800 to $632900^{\circ} \mathrm{C}$ in the metabasalt at $\sim 33 \mathrm{~km}$ depth imply that the overriding oceanic lithosphere was less than 633about 20 My-old. This is a maximum age as cooling of the slab/mantle interface due to slab 634penetration would imply a younger age. The reconstructed $\sim 33 \mathrm{~km}$ depth has geodynamic implications 635for the distance of the trench/megathrust to the ridge. Assuming subduction took place at a 636convergence rate of $2 \mathrm{~cm} / \mathrm{yr}$ (consistent with kinematics estimated by e.g. Bradley, 1989) with a $25^{\circ}$ 637dip of the slab indicates that $\sim 4$ Ma were necessary to subduct the high-grade metabasalts to peak 638pressure, which decreases to $\sim 2.3$ Ma for a $45^{\circ}$ slab dip. In any case the time required to bury mafic 639rocks of the future metamorphic sole to peak pressure is not insignificant but small compared to the 640age of the overriding lithosphere during underplating of the sole. This time lapse is short yet sufficient 641for heat transfer to the whole high-grade unit (always thinner than $100 \mathrm{~m}$, to be compared with the 642much larger lengths heat may travel in a Ma, e.g. Bickle and McKenzie, 1987). Overall, this model is 643consistent with subduction initiating close to (within tens of kilometres) or at the ridge and with 644metamorphic soles originating from ocean-floor rocks located close to the forming trench at the time 645of subduction initiation (also within tens of kilometres). Greater distances, convergence rates below $646 \mathrm{~cm} / \mathrm{yr}$ and shallow slab dipping require greater time for burial to peak pressure and become 647inconsistent with the thermal structure of oceanic lithosphere shown in figure 15a due to cooling of the 648mantle wedge. The supra-subduction zone origin of the ophiolitic complex proposed by many authors 649(see Tremblay et al., 2011) suggests that the oceanic lithosphere where subduction initiated (within the 650Iapetus ocean) could have been warmer than presented in figure 15a. This resonates with the global 651scale analysis of Vaughan and Scarrow (2003) who link thermal rejuvenation of the oceanic 652lithosphere to ophiolite obduction. Unfortunately testing for thermal rejuvenation is beyond the 653resolution of the geological record of the Mont Albert ophiolitic complex, especially as peridotites 654remain too poorly dated to compare with peak metamorphism ages in the sole. 
656The mineral record of the Mont Albert metamorphic sole argues for hair-pin yet clockwise pressure657temperature paths with exhumation along a warmer geothermal gradient than during burial. Although 658this is counter-intuitive, given the progressive cooling of the plate interface (and the trajectories of 659Hacker and Gnos, 1997), this is explained by rapid vertical movements in comparison of thermal re660equilibration of the overriding plate, as tentatively depicted in figure 15b-c.

661 Figure 15b and c show ocean-floor basalts buried below the plate interface, in a nascent subduction 662zone concomitantly of downward advection of isotherms (heating below the plate interface is 663comparatively slow: step 1 on Fig. 15b-c). Over time, isotherms in the lower plate are increasingly 664parallel to the plate interface. The thermal gradient through the plate interface to the upper plate 665increases with time, explaining the near-isobaric temperature increase of the high-grade unit during its 666accretion (step 2 on Fig. 15b-c). Exhumation follows along the base of the upper plate together with 667peridotites. Through the still sharp temperature gradient, exhumation explains initially rapid cooling 668(step 3) continuing along a warmer thermal gradient than burial (via step 4). With time, the plate 669interface has been cooling significantly (compare isotherms at t1 and t4). This schematic model is only 670valid if the upper plate remains significantly warmer over a distance of several tens of meters above 671the plate interface during the time of exhumation of the metamorphic sole (i.e. a few millions years, in 672agreement with radiometric constraints discussed above). Preservation of peak temperature mineral 673assemblages above $700^{\circ} \mathrm{C}$ and of subsequent parageneses without homogenization by diffusion are 674also consistent with fast cooling. 7.2.3.Melting... or not?

676In the Mont Albert ophiolitic complex, absence of metasediments from the rocks less than 20 metres 677away from to the contact with the peridotite is observed in a trend where the proportion of sediments 678and their quartz content apparently increase towards the base of the sole. This has also been noted in 679the Semail metamorphic sole (e.g. Soret et al., 2017). In their model, Agard et al. (2016) point out that 680ocean-floor derived subducted rocks likely contain more sediments with time as distance to the margin 681decreases (following closure of the basin).

682Alternatively, the absence of metasediments from the first 20 metres may be related to melting: close 683to the contact, metamorphic conditions are well above $700^{\circ} \mathrm{C}$ and aluminous metapelites should have 
684been molten at a significant degree ( $>30 \%$ ), consistently with observations of geochemical tracers of 685subducted sediments within arc magmas (e.g. Labanieh et al., 2012; Plank et al., 2009). Melts 686produced from the metasediments and from the amphibolite should have near granitic composition at 687peak conditions (see Feisel et al., 2018 for open system amphibolite melting at $0.95 \mathrm{GPa}$ ) and should 688produce easily identifiable leucosomes. However leucosomes and melt remnants are rare throughout 689the sole and have not been found closer than about 20 metres from the contact or crosscutting the 690peridotite. The restite of molten sediments may have been missed in the field (it is probably dark 691within dark mafic rocks), especially as shearing has been intense and proportions of metasediments are 692small in comparison to mafic rocks. Corundum-epidote-chlorite rocks found within the amphibolite 693less than 10 metres away from the contact may record interactions between partially molten 694metapelites and mafic rocks, but these are rare and cryptic.

695Generalized partial melting is predicted in all present rock types above $750^{\circ} \mathrm{C}$. Soret et al. (2017) 696argue that limited melting of the metabasalts may enhance accretion, with a threshold around 7\% 697partial melting, above which melting would cause too much weakening to allow accretion. This 698suggests that metasediment-derived melts were mostly extracted parallel to the slab, and/or that melt699rich lithologies were not accreted to the upper plate peridotite and subsequently subducted and lost to 700the mantle. In this view, the absence of metasediments close to the contact would be explained (in the 701model of Agard et al., 2016) as due to a too large decrease in effective viscosity (because of melting) 702to allow coupling and accretion to the upper plate. It follows that what has been identified as the high703grade metamorphic sole unit could be a more complex assemblage of small (tens of metres in 704thickness at most) subunits, as in the Semail metamorphic sole (Soret et al., 2017). A possible 705consequence is that mafic rocks located immediately at the contact with the peridotite and lacking 706metapelites could have formed at higher pressure than estimated here (since pressure is possibly 707estimated with larger uncertainties in mafic rocks). Pressure estimates in horizons with pelitic and 708mafic lithologies nevertheless concur (e.g., figure 14a).

\section{CONCLUSION}

710The metamorphic sole of the Mont Albert ophiolitic complex and its relicts of metasediments provide 711clues to understand early subduction dynamics. As for the Semail ophiolite, a strong, seemingly 
712inverted metamorphic gradient is observed within the two main subunits respectively characterized by 713granulite / higher amphibolite facies and higher greenschist facies metamorphism. The metamorphic 714sole appears derived from the Schick-Shock volcanics from the Dunnage zone, and its petrology 715suggests a shallow, ocean-floor origin (basalt and sediments, although the absence of gabbro is hard to 716prove unequivocally).

717Limited retrogression and presence of aluminous metapelites allow constraining the metamorphic 718history of the high-grade unit to peak pressure around $0.95 \mathrm{GPa}$ with peak temperatures up to about $719850^{\circ} \mathrm{C}$. These estimates are consistent with the model proposed by Agard et al. (2016), where the 720metamorphic sole formed in a nascent subduction zone, below young (less than $\sim 20 \mathrm{Ma}$ ) or 721rejuvenated oceanic lithosphere, with burial along a geothermal gradient around $20^{\circ} \mathrm{C} / \mathrm{km}$. This study 722provides evidence for a clockwise metamorphic path, with exhumation of the high-grade units along a 723warmer geothermal gradient $\left(\sim 40^{\circ} \mathrm{C} / \mathrm{km}\right)$, suggesting rapid exhumation (i.e., faster than thermal re724equilibration and cooling of the mantle wedge above the plate interface). Cooling of the interface is 725documented by successive underplating of subunits with progressively lower peak metamorphic 726conditions (away from the contact with the peridotite). The necessarily fast pace of evolution of the 727metamorphic sole of the Mont Albert ophiolitic complex (formation below warm oceanic lithosphere, 728underplating and exhumation) is consistent with the narrow range of ages obtained by Tremblay et al. 729(2011) for the Thetford-Mines ophiolitic complex along the same suture zone: oceanic magmatism (at 730 480 Ma), formation of the high-grade metamorphic sole (at $476 \mathrm{Ma}$ ), emplacement of sole-derived 731melting products in the peridotite (at $\sim 470 \mathrm{Ma}$ ) and cooling of the metamorphic sole (from $\sim 466$ Ma to 732the end of obduction around $460 \mathrm{Ma}$ ), all took place within $20 \mathrm{Ma}$. Although partial melting is 733reported in Taconian ophiolitic soles (e.g. at the Thetford-Mines ophiolite: Tremblay et al., 2011; the 734Bay of Islands complex: Suhr and Cawood, 1993), evidenced in metapelites and predicted by 735thermodynamic modelling in mafic rocks (up to $~ 9$ vol.\%) at the Mont Albert ophiolitic complex, melt 736remnants such as leucosomes, granitoids or felsic intrusions are sparse. This may relate to strain 737localization in melt-rich lithologies, precluding coupling and favouring accretion of the mafic 738lithologies now found close to the contact with the overlying peridotite. Strain localisation during 739melting and melt drainage appear linked to stepwise accretion of subunits to form metamorphic soles, 
740consistently with pulsatile melting during prograde metamorphism (e.g. Diener and Fagereng, 2014) 741and with similar mechanisms observed in the metamorphic sole of the Semail ophiolite (Soret et al., 7422017).

\section{ACKNOWLEDGEMENTS}

744This work was financially supported by the CNRS INSU programs, by the ON:LAP project (ANR 745blanche, SIMI6; 2010 BLAN 615 01) and by ISTeP. We thank L. Labrousse for his help in organizing 746field trips; O. Boudouma for his expertise with SEM characterisation; M. Fialin and N. Rividi for help 747with EPMA; A. Le Meur, C. Finco and A. Rambert for their careful work on mineralogy during 748internships; B. Lefeuvre for his help during the second field trip; A. Plunder and C. Prigent for fruitful 749discussions. We are also indebted to C. Isabel and M. L'Italien from SEPAQ for authorizing access to 750restricted areas and for their kind help and advice during field trips for reaching outcrops. Constructive 751comments on the first version of the manuscript by J. Wakabayashi, P. Lanari, an anonymous reviewer 752and editor T. Pettke are gratefully acknowledged.

\section{REFERENCES}

754 Alcock F J. (1927). La région cartographiée du Mont Albert, Québec; Memoir no. 144 of the 755Geological Survey of Canada, 79 pages (plus 2 sheets) doi:10.4095/119929

756 Agard P., Searle M. P., Alsop G. I., Dubacq B. (2010). Crustal stacking and expulsion tectonics 757during continental subduction: P-T deformation constraints from Oman. Tectonics 29, TC5018. 758doi: 10.1029/2010TC002669

759 Agard P., Yamato P., Soret M., Prigent C., Guillot S., Plunder A., Dubacq B., Monié P. \& 760Chauvet A. (2016). Plate interface rheological switches during subduction infancy: control on slab 761penetration and metamorphic sole formation. Earth Planetary Science Letters 451, 208-220.

762 Beaudin J. (1983). Analyse structurale du groupe ShickShock et de la péridotite alpine du Mont 763Albert, Gaspésie. Ph.D. thesis, Université Laval, Sainte-Foy (Québec).

764 Boudier F., Nicolas, A. \& Bouchez, J. L. (1982). Kinematics of oceanic thrusting and subduction 765from basal sections of ophiolites. Nature 296, 825-828.

766 Bourdelle F. \& Cathelineau M. (2015). Low-temperature chlorite geothermometry: a graphical 767representation based on a T-R ${ }^{2+}-$ Si diagram. European Journal of Mineralogy 27, 617-626. 
769Appalachian Orogen. Tectonics 8, 1037-1049.

770 Bucher K., de Capitani C. \& Grapes R. (2005). The development of a margarite-corundum 771blackwall by metasomatic alteration of a slice of mica schist in ultramafic rock, Kvesjøen, Norwegian 772Caledonides. The Canadian Mineralogist 43, 129-156.

773 Camiré G., La Flèche M. \& Jenner G. (1995). Geochemistry of pre-Taconian mafic volcanism in 774the Humber Zone of the northern Appalachians, Québec, Canada. Chemical Geology 119, 55-77.

775 Cawood P. A. \& Suhr G. (1992). Generation and obduction of ophiolites: Constraints from the 776Bay of Islands Complex, western Newfoundland. Tectonics 11, 884-897.

777 Cesare B., Acosta-Vigil A., Bartoli O. \& Ferrero S. (2016). What can we learn from melt 778inclusions in migmatites and granulites? Lithos 239, 186-216.

779 Cowan R. J., Searle M. P. \& Waters D. J. (2014). Structure of the metamorphic sole to the Oman 780Ophiolite, Sumeini Window and Wadi Tayyin: implications for ophiolite obduction processes. 781Geological Society of London, Special Publication 392, 155-175.

782 Dewey J. F. (1976). Ophiolite obduction. Tectonophysics 31, 93-120.

783 De Souza S., Tremblay A., Ruffet G. \& Pinet N. (2012). Ophiolite obduction in the Quebec 784Appalachians, Canada - 40Ar/39Ar age constraints and evidence for syn-tectonic erosion and 785sedimentation. Canadian Journal of Earth Sciences 49, 91-110.

786 De Souza S., Tremblay A. \& Ruffet G. (2014). Taconian orogenesis, sedimentation and 787magmatism in the southern Quebec-northern Vermont Appalachians: Stratigraphic and detrital 788mineral record of Iapetan suturing. American Journal of Science 314, 1065-1103.

789 Diener J. F. A. \& Fagereng Å. (2014). The influence of melting and melt drainage on crustal 790rheology during orogenesis. Journal of Geophysical Research: Solid Earth 119, 6193-6210.

791 Dimo-Lahitte A., Monié P. \& Vergély P. (2001). Metamorphic soles from the Albanian 792ophiolites: Petrology, 40Ar/39Ar geochronology, and geodynamic evolution. Tectonics 20, 1, 78-96.

793 Duretz T., Agard P., Yamato P., Ducassou C., Burov E. \& Gerya T. V. (2016). Thermo794mechanical modeling of the obduction process based on the Oman Ophiolite case. Gondwana 795Research 32, 1-10. 
796 Ellis D. \& Green D. (1979). Experimental-study of the effect of Ca upon garnet-clinopyroxene 797Fe-Mg exchange equilibria. Contributions to Mineralogy and Petrology 71, 13-22.

798 Feisel Y., White R. W., Palin R. M. \& Johnson T. E. (2018). New constraints on granulite facies 799metamorphism and melt production in the Lewisian Complex, northwest Scotland. Journal of 800Metamorphic Geology 36, 6, 799-819.

801 Gagnon Y.D. \& Jamieson R.A. (1986). Étude de la semelle métamorphique du complexe du 802Mont Albert, Gaspésie, Québec. Commission géologique du Canada, Current Research part 803B/Recherches En Cours Partie B; Études no. 86-1B, 1-10, doi: 10.4095/120623

804 Gnos E. (1998). Conditions of Garnet Amphibolites Beneath the Semail Ophiolite: Implications 805for an Inverted Pressure Gradient. International Geological Review 40, 281-304.

806 Gray D. R. \& Gregory R. T. (2000). Implications of the structure of the Wadi Tayin metamorphic 807sole, the Ibra-Dasir block of the Samail ophiolite, and the Saih Hatat window for late stage extensional 808ophiolite emplacement, Oman. Marine Geophysical Research 21, 211-227.

809 Green E. C. R., White R. W., Diener J. F. A., Powell R., Holland T. J. B. \& Palin R. M. (2016). 810Activity-composition relations for the calculation of partial melting equilibria in metabasic rocks. 811Journal of Metamorphic Geology 34, 845-869.

812 Guilmette C., Indares A. \& Hébert R. (2011). High-pressure anatectic paragneisses from the 813Namche Barwa, Eastern Himalayan syntaxis: Textural evidence for partial melting, phase equilibria 814modeling and tectonic implications. Lithos 124, 66-81.

815 Gueddari K., Flèche M. R. L. \& Camiré G. (1999). Premières données sur la géochimie des 816éléments du groupe du platine (EGP) dans les péridotites du mont Albert (Québec). Comptes Rendus 817de l'Académie des Sciences - Series IIA 329 479-486,

818 Hacker B. R. (1991). The role of deformation in the formation of metamorphic gradients: Ridge 819subduction beneath the Oman Ophiolite. Tectonics 10, 455-473.

820 Hacker B. R. \& Gnos E. (1997). The conundrum of Samail: explaining the metamorphic history. 821Tectonophysics 279, 1, 215-226.

822 Hacker B. R. \& Mosenfelder J. L. (1996). Metamorphism and deformation along the 823emplacement thrust of the Samail ophiolite, Oman. Earth Planetary Science Letters 144, 435-451. 
825Thermal and geochronologic constraints. Tectonics 15, 1230-1247.

826 Holdaway M. J. (1972). Thermal stability of Al-Fe epidote as a function of $\mathrm{fO}_{2}$ and Fe content. 827Contributions to Mineralogy and Petrology 37, 307-340.

828 Holdaway M. J. (2000). Application of new experimental and garnet Margules data to the garnet829biotite geothermometer. American Mineralogist 85, 881.

830 Henry D. J., Guidotti C. V. \& Thomson J. A. (2005). The Ti-saturation surface for low-to831medium pressure metapelitic biotites: Implications for geothermometry and Ti-substitution 832mechanisms. American Mineralogist 90, 2-3, 316-328.

833 Holland T. J. B. \& Blundy J. (1994). Non-ideal interactions in calcic amphiboles and their 834bearing on amphibole-plagioclase thermometry. Contributions to Mineralogy and Petrology 116, 433835447.

836 Holland T. J. B. \& Powell R. (1998). An internally-consistent thermodynamic dataset for phases 837of petrological interest. Journal of Metamorphic Geology 16, 309-344.

838 Holland T. J. B. \& Powell R. (2003). Activity-composition relations for phases in petrological 839calculations: an asymmetric multicomponent formulation. Contributions to Mineralogy and Petrology 840145, 4, 492-501.

841 Holland T. J. B. \& Powell R. (2011). An improved and extended internally consistent 842thermodynamic dataset for phases of petrological interest, involving a new equation of state for solids. 843Journal of Metamorphic Geology 29, 333-383.

844 Ishikawa T., Fujisawa S., Nagaishi K. \& Masuda T. (2005). Trace element characteristics of the 845fluid liberated from amphibolite-facies slab: Inference from the metamorphic sole beneath the Oman 846ophiolite and implication for boninite genesis. Earth Planetary Science Letters 240, 355-377.

847 Jamieson R. A. (1986). P-T paths from high temperature shear zones beneath ophiolites. Journal 848of Metamorphic Geology 4, 3-22.

849 Kohn M. J. (2003). Geochemical zoning in metamorphic minerals. In: Holland, H. D. \& 850Turekian, K. K. (eds.) Treatise on Geochemistry. Oxford: Pergamon, pp. 229-261. 
851 Krogh Ravna E. J. (1988). The garnet-clinopyroxene Fe-Mg geothermometer - a reinterpretation 852of existing experimental-data. Contributions to Mineralogy and Petrology 99, 44-48.

853 Krogh Ravna E. J. (2000). The garnet-clinopyroxene $\mathrm{Fe}^{2+}-\mathrm{Mg}$ geothermometer: an updated 854calibration. Journal of Metamorphic Geology 18, 211-219.

855 Labanieh S., Chauvel C., Germa A. \& Quidelleur X. (2012). Martinique: a Clear Case for 856Sediment Melting and Slab Dehydration as a Function of Distance to the Trench. Journal of Petrology 85753, 12, 2441-2464.

858 Laurent R. \& Hebert Y. (1979). Paragenesis of serpentine assemblages in harzburgite tectonite 859and dunite cumulate from the Quebec Appalachians. The Canadian Mineralogist 17, 857-869.

860 Lardeaux J. M. \& Spalla M. I. (1991). From granulites to eclogites in the Sesia zone (Italian 861Western Alps): a record of the opening and closure of the Piedmont ocean. Journal of Metamorphic 862Geology 9, 35-59.

863 Leake B. E., Woolley A. R., Arps C. E. S., Gilbert M. C., Grice J. D., Hawthorne F. C., Kisch H. 864J., Krivovichev V. G., Canada J. A. M., Maresch W. V., Schumacher J. C., France D. C. S., 865Stephenson N. C. N. \& Whittaker E. J. W. (1997). Nomenclature of amphiboles. Canadian 866Mineralogist 35, 219-246.

867 Linckens J., Herwegh M. \& Müntener O. (2011). Linking temperature estimates and 868microstructures in deformed polymineralic mantle rocks. Geochemistry, Geophysics, Geosystems 12, 8698, doi: 10.1029/2011GC003536.

870 Lux D. R. (1986). ${ }^{40} \mathrm{Ar} /{ }^{39} \mathrm{Ar}$ ages for minerals from the amphibolite dynamothermal aureole, Mont 871Albert, Gaspé, Quebec. Canadian Journal of Earth Sciences 23, 1, 21-26.

872 MacGregor I. D. (1964). A study of the contact metamorphic aureole surrounding the Mount 873Albert ultramafic intrusion [Ph.D. dissert.] Princeton, New Jersey, Princeton University, 195 p.

874 MacGregor I. D. \& Basu A. R. (1979). Petrogenesis of the Mount Albert Ultramafic Massif, 875Quebec Geological Society of America Bulletin 90, 1529-1627.

876 Mahmood K., Boudier F., Gnos E., Monié P. \& Nicolas A. (1995). ${ }^{40} \mathrm{Ar} /{ }^{39} \mathrm{Ar}$ dating of the 877emplacement of the Muslim Bagh ophiolite, Pakistan. Tectonophysics 250, 169 - 181. 
878 Malo M., Cousineau P. A., Sacks P. E., Riva J. F., Asselin E. \& Gosselin P. (2001). Age and 879composition of the Ruisseau Isabelle Mélange along the Shickshock Sud fault zone: constraints on the 880timing of mélanges formation in the Gaspé Appalachians. Canadian Journal of Earth Sciences 38, 2188142.

882 Malo M., Ruffet G., Pincivy A. \& Tremblay A. (2008). A 40Ar/39Ar study of oceanic and 883continental deformation processes during an oblique collision: Taconian orogeny in the Quebec 884reentrant of the Canadian Appalachians. Tectonics 27, TC4001.

885 Martin J.-P. \& Germain D. (2016). Late-glacial and Holocene evolution as a driver of diversity 886and complexity of the northeastern North American alpine landscapes: a synthesis. Canadian Journal 887of Earth Sciences 53, 494-505.

888 McKenzie D., Jackson J. \& Priestley K. (2005). Thermal structure of oceanic and continental 889lithosphere. Earth and Planetary Science Letters 233, 337-349.

890 Messiga B. \& Bettini E. (1990). Reactions behaviour during kelyphite and symplectite formation: 891a case study of mafic granulites and eclogites from the Bohemian Massif. European Journal of 892Mineralogy 2, 125-144.

893 Nicollet C., Leyreloup A. \& Dupuy C. (1979). Petrogenesis of High Pressure Trondhjemitic 894Layers in Eclogites and Amphibolites from Southern Massif Central, France. in Trondhjemites, 895Dacites, and Related Rocks, Ed: Barker, F. (Ed.) 6, 435-463.

896 O'Beirne-Ryan A. M., Jamieson R. A. \& Gagnon Y. D. (1990). Petrology of garnet897clinopyroxene amphibolites from Mont Albert, Gaspé, Quebec. Canadian Journal of Earth Sciences 89827, 72-86.

899 Olejczyk P. \& Gray J. T. (2007). The relative influence of Laurentide and local ice sheets during 900the last glacial maximum in the eastern Chic-Chocs Range, northern Gaspé Peninsula, Quebec. 901Canadian Journal of Earth Sciences 44, 1603-1625.

902 Operta M., Pamić J., Balen D. \& Tropper P. (2003). Corundum-bearing amphibolites from the 903metamorphic basement of the Krivaja--Konjuh ultramafic massif (Dinaride Ophiolite Zone, Bosnia). 904Mineralogy and Petrology 77, 287-295. 

906modelling of retrograde amphibole and clinozoisite in mafic eclogite from the Tso Morari massif, 907northwest India: constraining the $\mathrm{P}-\mathrm{T}-\mathrm{M}\left(\mathrm{H}_{2} \mathrm{O}\right)$ conditions of exhumation. Journal of Metamorphic 908Geology 32, 675-693.

909 Palin R. M., White R. W., Green E. C. R., Diener J. F. A., Powell R. \& Holland T. J. B. (2016). 910High-grade metamorphism and partial melting of mafic and intermediate rocks. Journal of 911Metamorphic Geology 34, 871-892.

912 Pincivy A., Malo M., Ruffet G., Tremblay A. \& Sacks P. (2003). Regional metamorphism of the 913Appalachian Humber zone of Gaspé Peninsula: ${ }^{40} \mathrm{Ar} /{ }^{39} \mathrm{Ar}$ evidence for crustal thickening during the 914Taconian Orogeny. Canadian Journal of Earth Sciences 40, 2, 301-315.

915 Pinet N. \& Tremblay A. (1995). Tectonic evolution of the Quebec-Maine Appalachians: from 916oceanic spreading to obduction and collision in the Northern Appalachians. American Journal of 917Science 295, 2, 173-200.

918 Plank T., Cooper L. B. \& Manning C. E. (2009). Emerging geothermometers for estimating slab 919surface temperatures. Nature Geoscience 2, 611-615.

920 Plunder A., Agard P., Chopin C., Soret M., Okay A. I. \& Whitechurch H. (2016). Metamorphic 921sole formation, emplacement and blueschist facies overprint: early subduction dynamics witnessed by 922western Turkey ophiolites. Terra Nova 28, 329-339.

923 Powell R. (1985). Regression diagnostics and robust regression in geothermometer/geobarometer 924calibration: the garnet-clinopyroxene geothermometer revisited. Journal of Metamorphic Geology 3, 925231-243.

926 Pratt J. H. (1906). Corundum and its occurrence and distribution in the United States (a revised 927and enlarged edition of Bulletin 180). USGS Numbered Series 269, 175 p., 928https://pubs.er.usgs.gov/publication/b269

929 Prigent C., Agard P., Guillot S., Godard M. \& Dubacq B. (2019). Mantle Wedge (De)formation 930During Subduction Infancy: Evidence from the Base of the Semail Ophiolitic Mantle. Journal of 931Petrology 59, 11, 2061-2092. 

933subduction fluids into the deforming mantle wedge during nascent subduction: Evidence from trace 934elements and boron isotopes (Semail ophiolite, Oman). Earth and Planetary Science Letters 484, 213935228.

936 Rioux M., Garber J., Bauer A., Bowring S., Searle M., Kelemen P. \& Hacker B. (2016). 937Synchronous formation of the metamorphic sole and igneous crust of the Semail ophiolite: New 938constraints on the tectonic evolution during ophiolite formation from high-precision U-Pb zircon 939geochronology. Earth Planetary Science Letters 451, 185-195.

940 Schiffman P. \& Staudigel H. (1995). The smectite to chlorite transition in a fossil seamount 941hydrothermal system: the Basement Complex of La Palma, Canary Islands. Journal of Metamorphic 942Geology 13, 487-498.

943 Schmidt M. W. \& Poli S. (2004). Magmatic Epidote. Reviews in Mineralogy and Geochemistry, 944Mineralogical Society of America 56, 399-430.

945 Searle M. \& Cox J. (1999). Tectonic setting, origin, and obduction of the Oman ophiolite. 946Geological Society of America Bulletin 111, 104-122.

947 Searle M. \& Malpas J. (1982). Petrochemistry and origin of sub-ophiolitic metamorphic and 948related rocks in the Oman Mountains. Journal of the Geological Society, Geological Society of 949London 139, 235-248.

950 Searle M., Waters D., Garber J., Rioux M., Cherry A. \& Ambrose T. (2015). Structure and 951metamorphism beneath the obducting Oman ophiolite: Evidence from the Bani Hamid granulites, 952northern Oman mountains. Geosphere 11, 1812-1836.

953 Sirois L. \& Grandtner M. (1992). A phyto-ecological investigation of the Mount Albert 954serpentine plateau. in The Ecology of Areas with Serpentinized Rocks: A World View, Springer 955Netherlands Eds., 115-133.

956 Skelton A., Arghe F. \& Pitcairn I. (2010). Regional mapping of pre-metamorphic spilitization and 957associated chemical mobility in greenschist-facies metabasalts of the SW Scottish Highlands. Journal 958of the Geological Society 167, 5, 1049-1061. 
959 Soret M., Agard P., Dubacq B., Plunder A. \& Yamato P. (2017). Petrological evidence for 960stepwise accretion of metamorphic soles during subduction infancy (Semail ophiolite, Oman and 961UAE). Journal of Metamorphic Geology 35, 1051-1080.

962 Soret M., Agard P., Dubacq B., Vitale-Brovarone A., Monié P., Chauvet A., Whitechurch H. \& 963Villemant, B. (2016). Strain localization and fluid infiltration in the mantle wedge during subduction 964initiation: Evidence from the base of the New Caledonia ophiolite. Lithos 244, 1-19.

965 Spear F. (1993). Metamorphic Phase Equilibria and Pressure-Temperature-Time Paths 966Mineralogical Society of America, WashinGrton, D. C, 799 p.

967 Spray, J. G. (1984). Possible causes and consequences of upper mantle decoupling and ophiolite 968displacement. Geological Society, London, Special Publications 13, 255-268.

969 Spray J. G., Bebien J., Rex D. C. \& Roddick J. C. (1984). Age constraints on the igneous and 970metamorphic evolution of the Hellenic-Dinaric ophiolites. Geological Society of London, Special 971Publications 17, 619-627.

972 Suhr G. \& Cawood P. A. (1993). Structural history of ophiolite obduction, Bay of Islands, 973Newfoundland. Geological Society of America Bulletin 105, 399-410.

974 Tremblay A. \& Pinet N. (2016). Late Neoproterozoic to Permian tectonic evolution of the Quebec 975Appalachians, Canada. Earth Science Reviews 160, 131-170.

976 Tremblay A., Ruffet G. \& Bédard J. H. (2011). Obduction of Tethyan-type ophiolites - A case977study from the Thetford-Mines ophiolitic Complex, Quebec Appalachians, Canada. Lithos 125, 10-26 978 Tropper P. \& Recheis A. (2003). Garnet zoning as a window into the metamorphic evolution of a 979crystalline complex: the northern and central Austroalpine Ötztal-Complex as a polymorphic example. 980Mitteilungen der Österreichischen Geologischen Gesellschaft 94, 27-53.

981 Trzcienski W. E. (1988). Retrograde eclogite from Mont Albert, Gaspé, Quebec. Canadian 982Journal of Earth Sciences 25, 30-37.

983 Trzcienski W. E., Gromet L. P. \& Kinny P. (1995). Comparative conventional, Kober, and 984SHRIMP II analyses of zircons from within the Mont Albert, Gaspé, Québec, Canada Ultramafic 985Complex. Geological Society of America, Annual Meeting, New Orleans 27 (A 436). 
986 Vaughan A. P. \& Scarrow J. H. (2003). Ophiolite obduction pulses as a proxy indicator of 987superplume events? Earth and Planetary Science Letters 213, 407-416.

988 Vidal O., De Andrade V., Lewin E., Munoz M., Parra T. \& Pascarelli S. (2006). P-T989deformation- $\mathrm{Fe}^{3+} / \mathrm{Fe}^{2+}$ mapping at the thin section scale and comparison with XANES mapping: 990application to a garnet-bearing metapelite from the Sambagawa metamorphic belt (Japan). Journal of 991Metamorphic Geology 24, 669-683.

992 Wakabayashi J. (1990). Counterclockwise P-T-t Paths from Amphibolites, Franciscan Complex, 993California: Relics from the Early Stages of Subduction Zone Metamorphism. The Journal of Geology 99498, 657-680.

995 Wakabayashi J. \& Dilek Y. (2000). Spatial and temporal relationships between ophiolites and 996their metamorphic soles: A test of models of forearc ophiolite genesis. Geological Society of America 997Special Papers 349, 53-64.

998 Wakabayashi J. \& Dilek Y. (2003). What constitutes "emplacement" of an ophiolite?: 999Mechanisms and relationship to subduction initiation and formation of metamorphic soles. Geological 1000Society of London Special Publications 218, 427-447.

1001 Williams H. \& Grant A. C. (1998). Tectonic Assemblages Map, Atlantic Region, Canada. 1002 Geological Survey of Canada Open File 3657.

1003 White R. W., Powell R., Holland T. J. B., Johnson T. E. \& Green E. C. R. (2014a). New mineral 1004activity-composition relations for thermodynamic calculations in metapelitic systems. Journal of 1005Metamorphic Geology 32, 261-286.

1006 White R. W., Powell R. \& Johnson T. E. (2014b). The effect of Mn on mineral stability in 1007metapelites revisited: new a-x relations for manganese-bearing minerals. Journal of Metamorphic 1008Geology 32, 809-828.

1009 White R. W., Powell R., Holland T. J. B. and Worley A. (2000). The effect of $\mathrm{TiO}_{2}$ and $\mathrm{Fe}_{2} \mathrm{O}_{3}$ on 1010metapelitic assemblages at greenschist and amphibolite facies conditions: mineral equilibria 1011calculations in the system $\mathrm{K}_{2} \mathrm{O}-\mathrm{FeO}-\mathrm{MgO}-\mathrm{Al}_{2} \mathrm{O}_{3}-\mathrm{SiO}_{2}-\mathrm{H}_{2} \mathrm{O}-\mathrm{TiO}_{2}-\mathrm{Fe}_{2} \mathrm{O}_{3}$. Journal of Metamorphic 1012Geology 18, 497-511. 
1013 Whitehead J., Reynolds P. H. \& Spray J. G. (1995). The sub-ophiolitic metamorphic rocks of the 1014Québec Appalachians. Journal of Geodynamics 19, 325-350.

1015 Whitney D. L. \& Evans B. W. (2010). Abbreviations for names of rock-forming minerals. 1016American Mineralogist 95, 185-187.

1017 Williams H. (1979). Appalachian Orogen in Canada. Canadian Journal of Earth Sciences 16, 1018792-807.

1019 Williams H. \& Smyth W. R. (1973). Metamorphic aureoles beneath ophiolite suites and alpine 1020peridotites: tectonic implications with west Newfoundland examples. American Journal of Science 1021273, 594-621.

1022 Wolf M. B. \& Wyllie P. J. (1994). Dehydration-melting of amphibolite at 10 kbar: the effects of 1023temperature and time. Contributions to Mineralogy and Petrology 115, 369-383.

1024 Wu C. M. (2015). Revised empirical garnet-biotite-muscovite-plagioclase geobarometer in 1025metapelites. Journal of Metamorphic Geology 33, 167-176.

1026 Wu C. M. \& Chen H.-X. (2015). Calibration of a Ti-in-muscovite geothermometer for ilmenite1027and $\mathrm{Al}_{2} \mathrm{SiO}_{5}$-bearing metapelites. Lithos 212-215, 122-127.

1028 Wu C. M. \& Zhao G. (2006). Recalibration of the Garnet-Muscovite (GM) Geothermometer and 1029the Garnet-Muscovite-Plagioclase-Quartz (GMPQ) Geobarometer for Metapelitic Assemblages. 1030Journal of Petrology 47, 2357-2368.

1031 Wu C. M. \& Zhao G. C. (2007). The metapelitic garnet-biotite-muscovite-aluminosilicate-quartz 1032(GBMAQ) geobarometer. Lithos 97, 365-372.

1033 


\section{FIGURE CAPTIONS}

1035

a

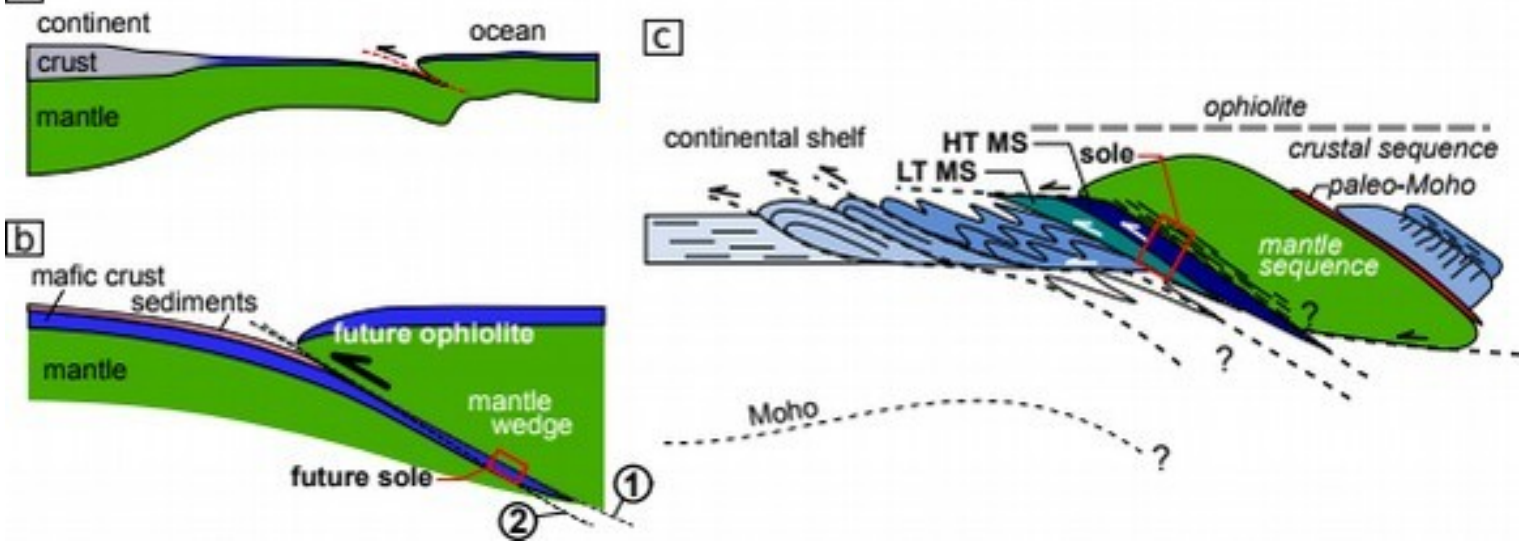

1036Figure 1: Schematic cross-sections showing the general geodynamic setting and its evolution during 1037subduction infancy and ophiolite obduction, with emphasis on the ophiolitic sole. Redrawn after 1038Agard et al. (2016) and Searle et al. (2015). (a) Intra-oceanic subduction initiation, prior to ophiolite 1039obduction. (b) Close-up view on the formation and accretion of the metamorphic sole to the mantle 1040wedge. Accretion of crustal-derived material implies displacement of the subduction interface from 1041thrust 1 to thrust 2. (c) Obduction of the ophiolite and its sole (red rectangle). The sole has an apparent 1042inverted metamorphic gradient and includes, from bottom to top: greenschist- and lower amphibolite 1043facies metamorphic rocks (LT MS: low temperature metamorphic sole), higher amphibole to granulite 1044facies metamorphic rocks (HT MS: high temperature), and peridotite of mantle origin showing 1045multiple deformation events (from $\sim 1200^{\circ} \mathrm{C}$ to $\sim 650^{\circ} \mathrm{C}$ : Linkens et al., 2011 ; Prigent et al., 2018). 1046The Mont Albert ophiolitic complex lacks the crustal sequence. 

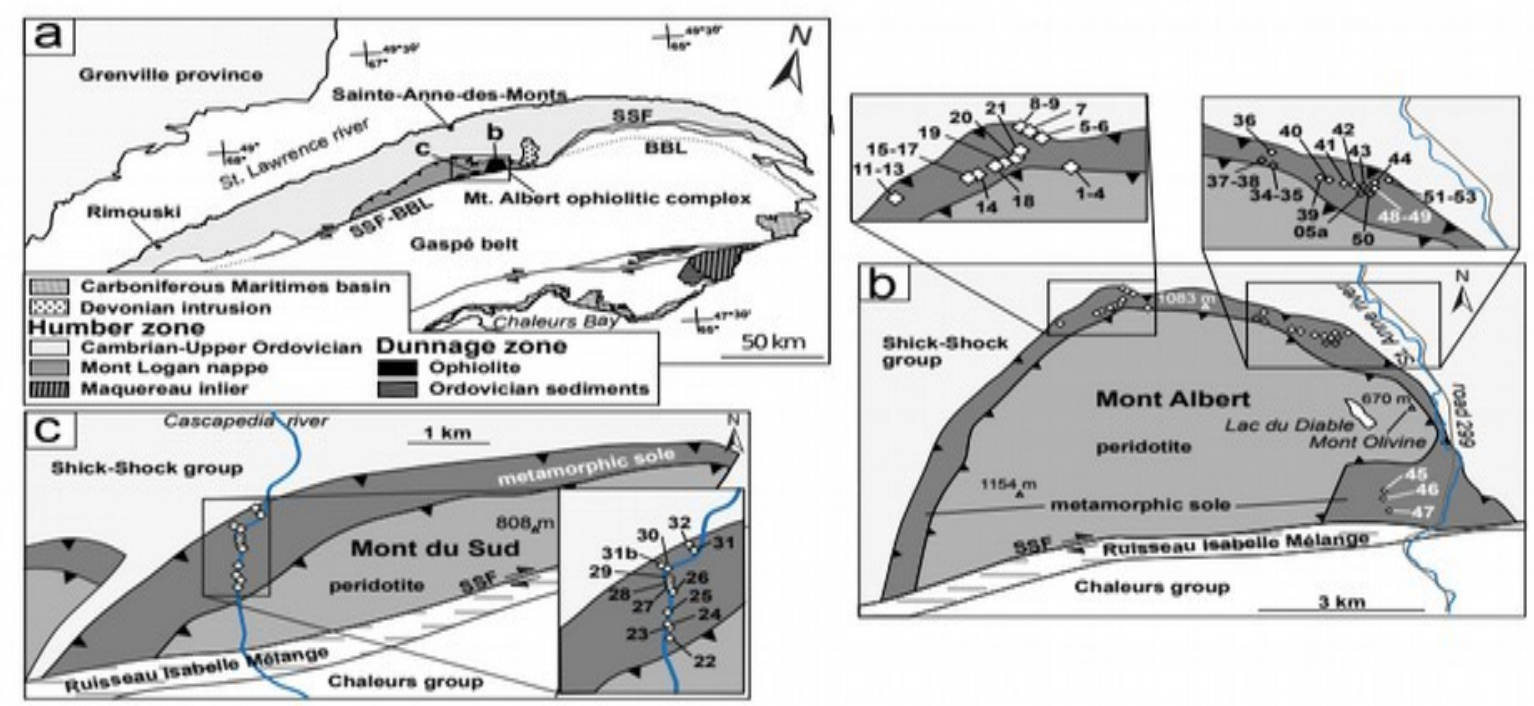

1049Figure 2: Geological maps of the Mont Albert ophiolitic complex and sample location. (a) Simplified 1050geological map of the Gaspé peninsula (modified after Malo et al., 2008 and Williams and Grant, 10511998). The Mont Albert ophiolitic complex is indicated by the central rectangle. (b) Simplified 1052geological map of the Mont Albert area (after MacGregor and Basu, 1979; Gagnon and Jamieson, 10531986). Numbers indicate sample location, as shown in insets for readability. (c) Geological map of the 1054Mont du Sud area (after the geological map available from SIGEOM http://sigeom.mines.gouv.qc.ca). 1055Sampling of the metamorphic sole was focused on the shore of the Cascapedia River. SSF: South 1056Schick-Schock Fault; BBL: Baie Verte-Brompton Line. 

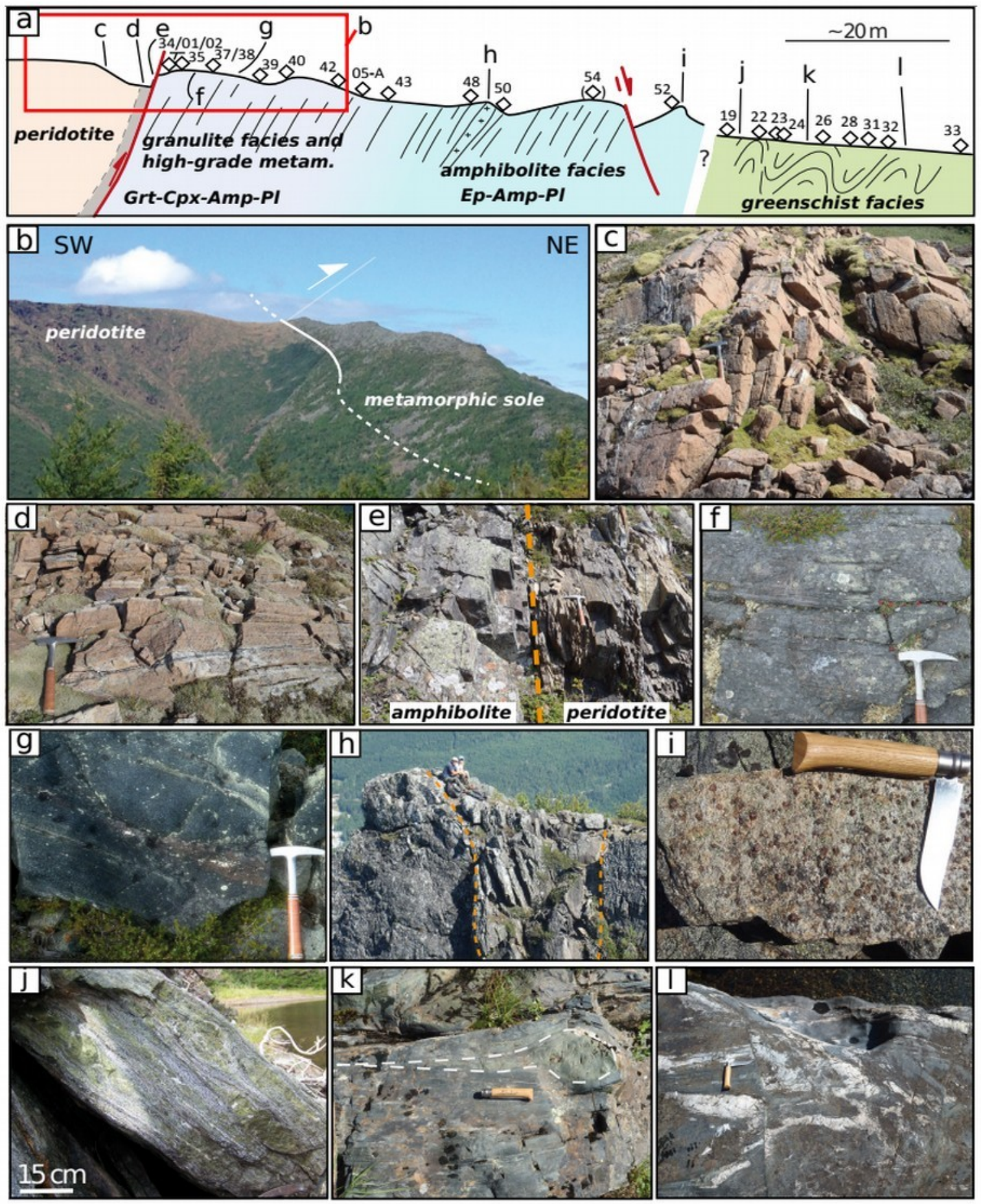

1059Figure 3: Representative geology of the base of the Mont Albert ophiolitic complex. (a) Schematic 1060cross-section, indicating the position of samples presented in this study (diamonds and numbers) and 1061the position of fields photographs underneath (letters). (b) Large-scale view from the summit of Mont 1062Olivine of the north-east ridge of Mont Albert, with peridotite on the left (brass colour) and 
1063amphibolite on the right (dark grey). The contact is partly hidden by vegetation and grey boulders 1064(dotted line). (c) Typical aspect of the peridotite away from the contact. (d) Serpentinite unit at the 1065base of the peridotite, with oxide-rich layers, north-east of the summit of Mont Albert. (e) The 1066peridotite / amphibolite contact as found on top of Mont Albert. (f) Typical aspect of the high-grade 1067garnet-clinopyroxene amphibolite. (g) Garnet-rich layer (left of hammer head) alternating with albite1068epidote rich layers (top of image) in the high-grade amphibolite. (h) View of a 'sill' (bounded by 1069orange dashes) along the north-east arête of Mont Albert, with quartz-plagioclase-hornblende in the 1070centre and quartz-mica-gedrite on the margins (samples MA-14-48-49 on Fig. 2b and 6j). Foliation is 1071subparallel to the intrusion. (i) Garnet-bearing metapelites along the 'Marches du Géant' normal fault 1072system, $\geq 40$ m away from the contact with the peridotite (near sample MA-14-50, Fig. 2b, 6a). (j), (k) 1073and (l) are typical outcrops of the low-grade amphibolite. Deformation is highlighted by quartz-albite1074epidote assemblages found in shear zones, as layers, veinlets and around deformed pillows 1075(highlighted in k). (j): west of summit of Mont Albert, near sample MA-14-19 (Fig. 2b and 5c). (k): 1076south of Mont Albert (near sample MA-14-46, Fig. 2b). (l) south-west of Mont du Sud near sample 1077MA-14-24 (Fig. 2c).

1078 


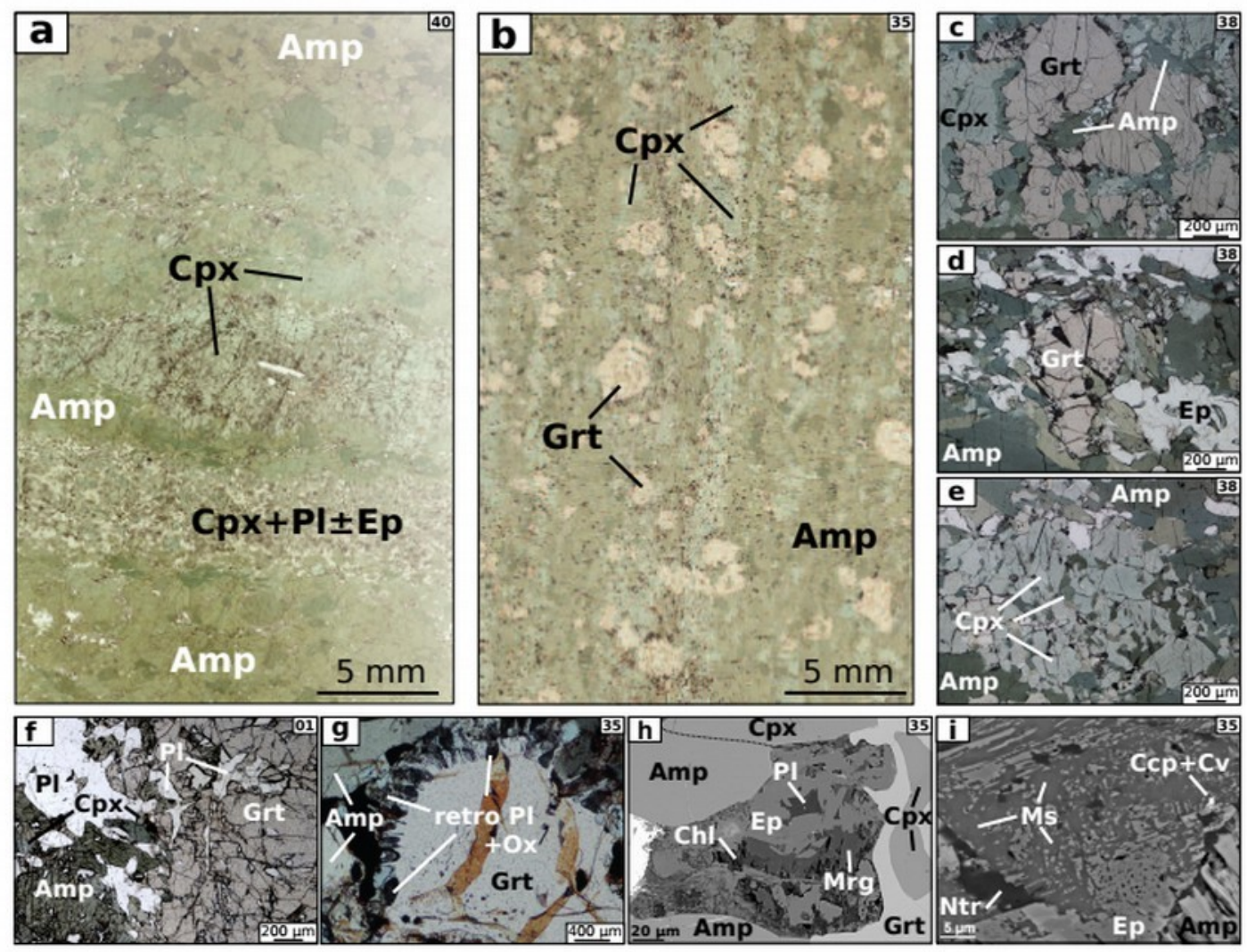

1080Figure 4: Typical aspect of high-grade amphibolite, with thin sections scans, microphotographs and 1081SEM images. (a) Clinopyroxene-rich amphibolite, without garnet. Foliation is roughly horizontal. 1082Amphibole varies from deep to paler green. Clinopyroxene (pale green, paler than amphibole) is often 1083found forming layers where large, fractured and deformed clinopyroxene crystals are surrounded by 1084smaller clinopyroxene crystals and plagioclase (translucent). (b) Garnet-clinopyroxene-epidote 1085amphibolite. Foliation is subvertical. (c-d-e) close-up microphotographs of sample MA-14-38, 1086showing $~ 500 \mu \mathrm{m}$ anhedral garnet crystals and aggregated smaller $(100-200 \mu \mathrm{m})$ euhedral garnet 1087crystals, both often with symplectitic rim (e). Epidote is a crystallisation product in the simplectite. 1088Clinopyroxene is found as $\geq 1 \mathrm{~mm}$ crystals and as $\sim 100 \mu \mathrm{m}$ crystals growing with amphibole. (e) 1089Clinopyroxene-amphibole symplectite. (f) Plagioclase-garnet-amphibole symplectite with minor 1090clinopyroxene. (g): sample MA-14-35; garnet rims with symplectite texture, retrogressed plagioclase 1091and Fe-Ti oxides. (h-i) close-up views of phases associated with retrogressed plagioclase within the 1092symplectite (note the texture of garnet, see also Fig. 7c). Plagioclase is preserved associated to epidote, 
1093and replaced by very fine epidote-muscovite intergrowths. Margarite, chlorite, sulfides and natrolite 1094appear as later alteration products.

1095 

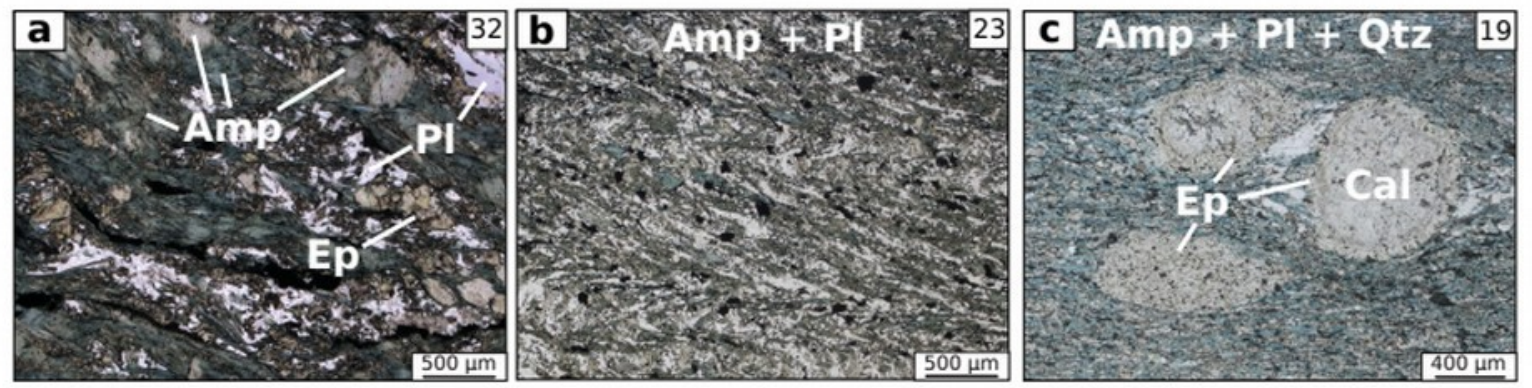

1097Figure 5: Selected thin section microphotographs of the low-grade amphibolite. (a) Plagioclase1098epidote amphibolite where amphibole shows pale green cores and darker blue-green rims. (b) Incipient 1099crenulation cleavage in schistose amphibolite, as typically found along the Cascapedia river. (c) 1100Calcite-epidote filled spherulites in amphibolite, with quartz and albite. Foliation is horizontal. 

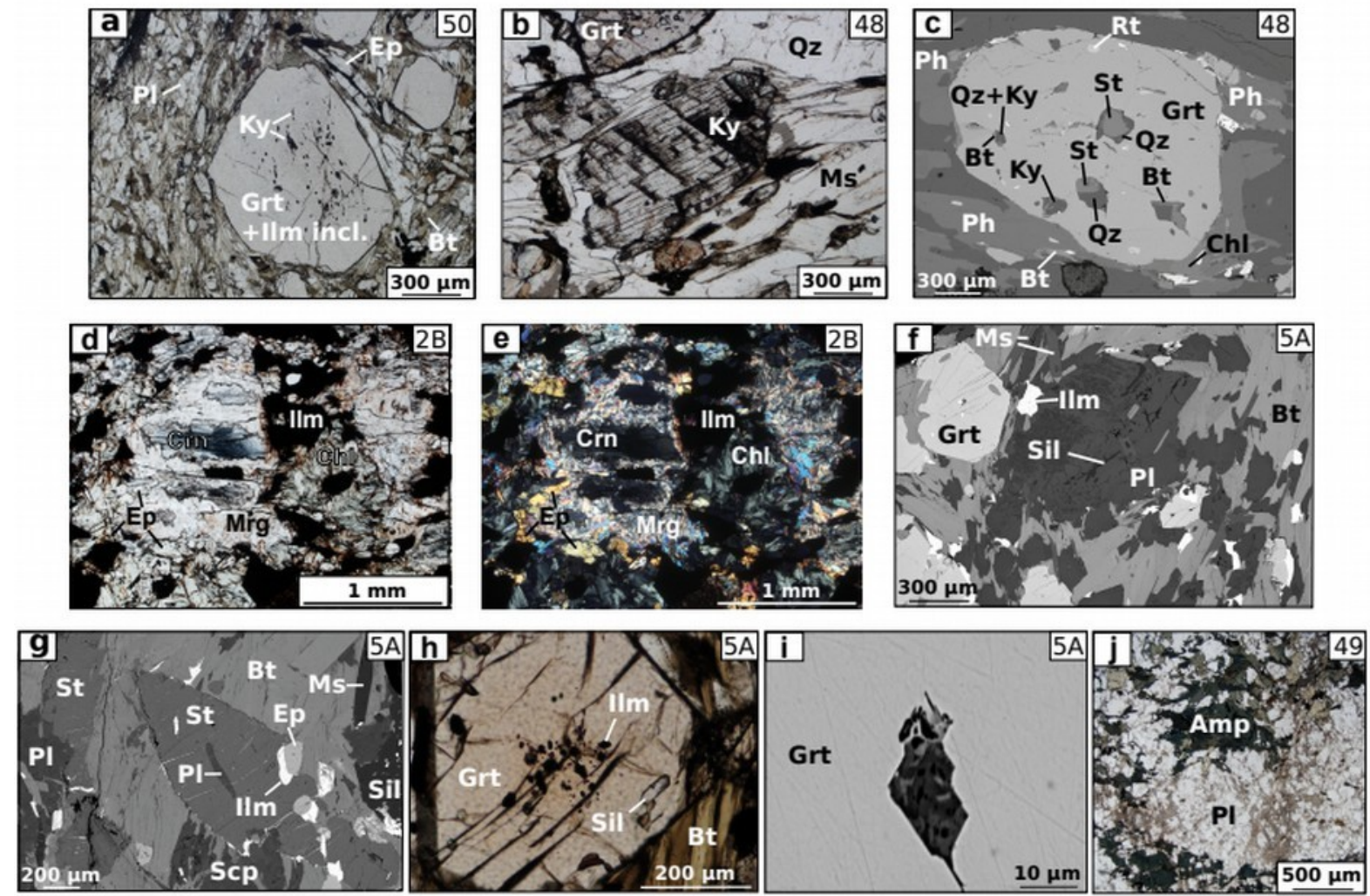

1103Figure 6: Representative mineralogy of metapelites and associated rocks found in the metamorphic 1104sole of Mont Albert. (a) Garnet-kyanite-biotite-plagioclase metapelite (see Fig. 3i). (b) Kyanite is 1105found as a porphyroclast and included in garnet (SEM image c). Garnet also includes staurolite, 1106biotite, quartz and rutile (c). (d - plane-polarized light) and (e - crossed polars) show 1107microphotographs of corundum-epidote-ilmenite assemblage in red oxide-rich layers, retrogressed to 1108margarite, chlorite, paragonite and diaspore (both too small to show on micrograph). (f-g-h-i) SEM 1109images and microphotographs of sample MA-15-05A, found $\sim 20 \mathrm{~m}$ away from the peridotite. 1110Sillimanite is observed as abundant needles in plagioclase (f) and in prismatic form associated with 1111scapolite and staurolite (g). These are both in the foliation and cross-cutting the foliation as in (g). (h) 1112and (i) show inclusions in garnet from biotite-rich layers, with oxides in the core and sillimanite in the 1113rim. SEM revealed that some inclusions have negative crystal shape and contain polycrystalline 1114silicates (too small for determination) together with apparent porosity. (j) Texture of the retrogressed 1115sill with millimetre-scale plagioclase and amphibole. 

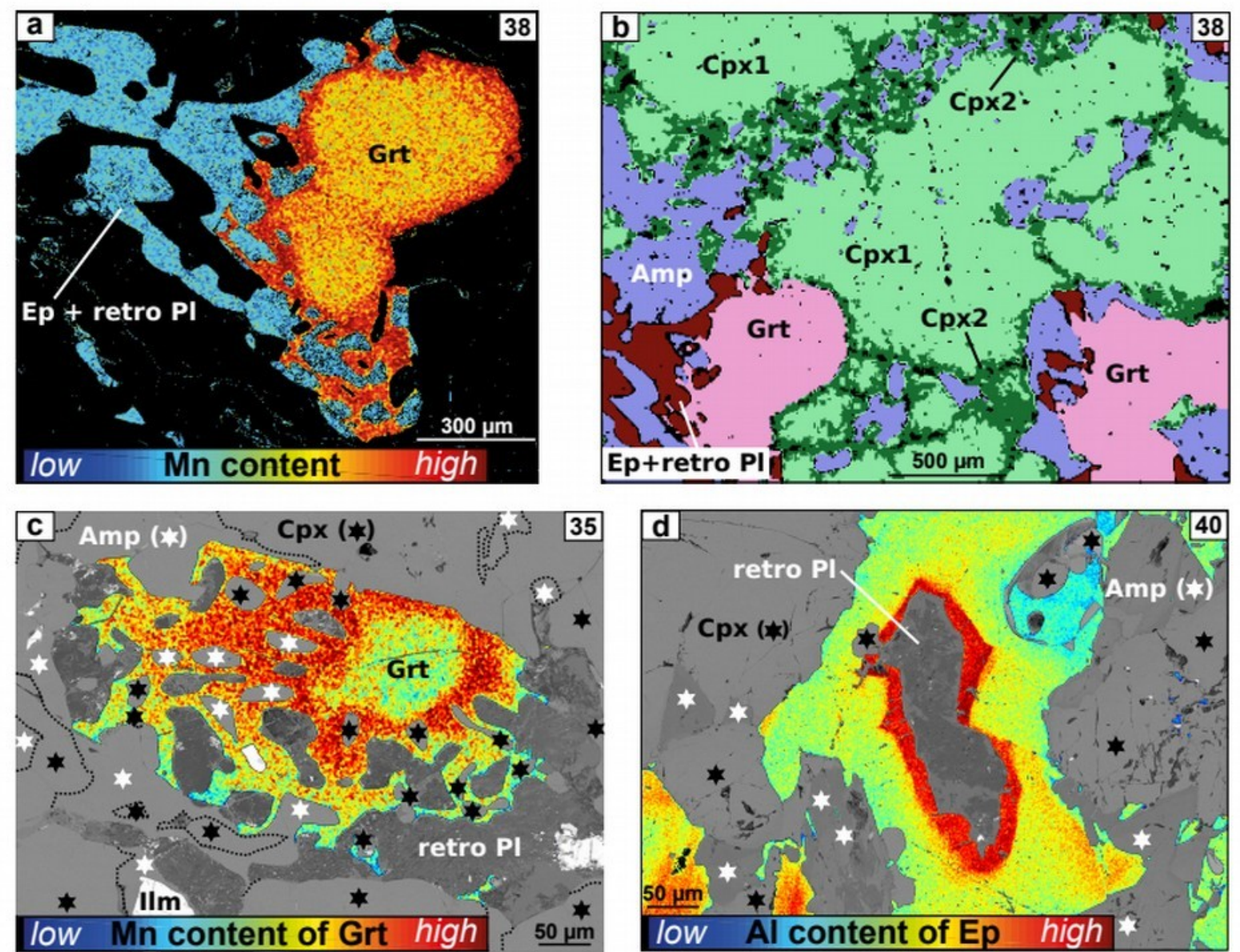

1118Figure 7: Texture and composition of minerals associated with the garnet-amphibole-clinopyroxene 1119symplectite. (a) and (b) Mineral assemblage and Mn content in sample MA-14-38. The symplectic 1120garnet rim has high $\mathrm{Mn}$, and is intimately associated to retrogressed plagioclase and epidote. Two 1121generations of clinopyroxene are unambiguously evidenced from their $\mathrm{Al}$ content (see corresponding 1122compositions in Fig. 8d). (c) Mn content of garnet over SEM image of texture of symplectite in 1123sample MA-14-35. Garnet is associated with amphibole, clinopyroxene, oxide and retrogressed 1124plagioclase (labelled "retro Pl”). Clinopyroxene and amphibole, hard to distinguish on SEM images, 1125are labelled with black and white stars respectively, and contoured with dotted lines. (d) Al content of 1126epidote over SEM image of epidote crystallised around retrogressed plagioclase. Clinopyroxene and 1127amphibole are intergrown on each side of the image and labelled as in (c). 

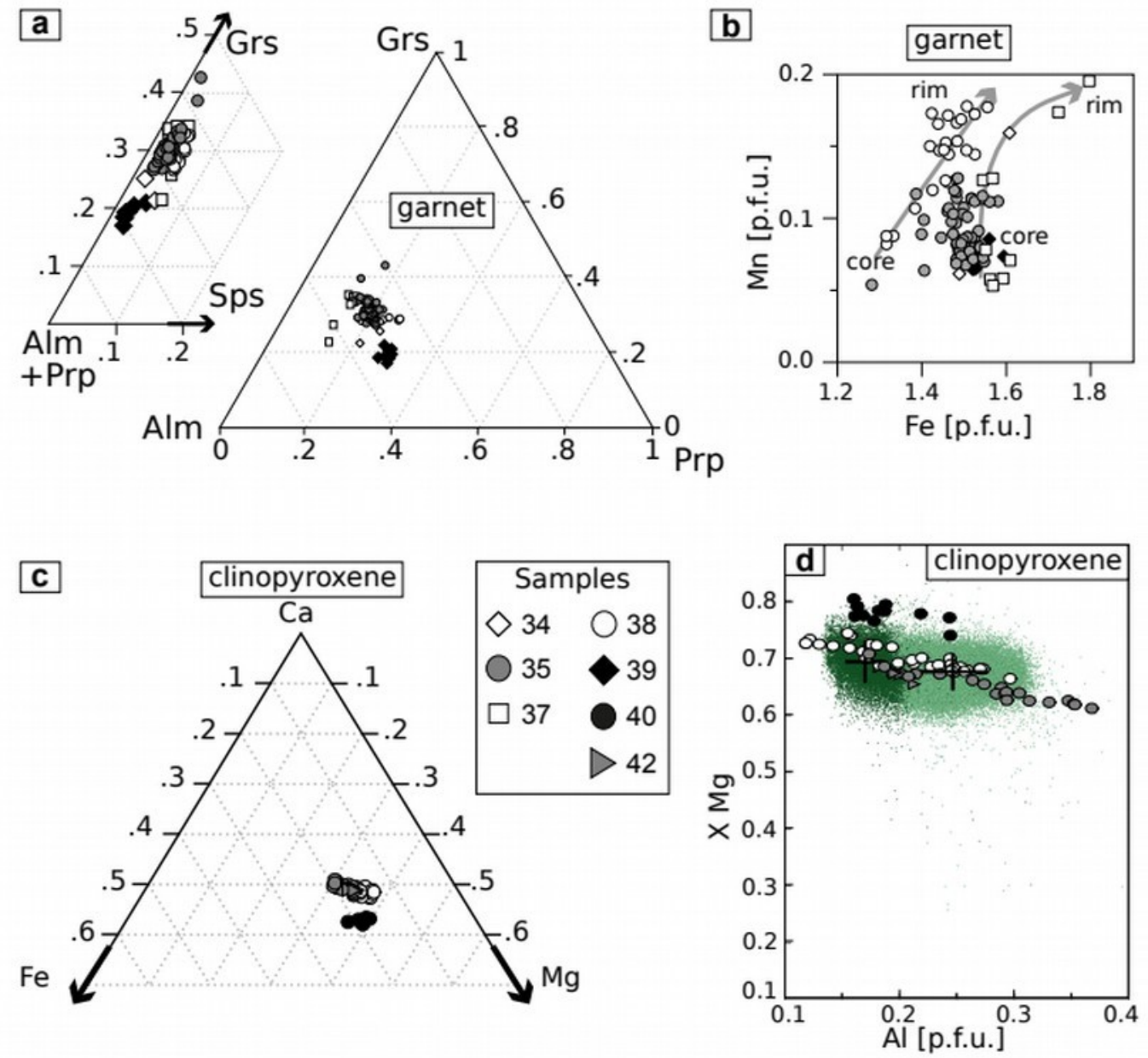

1130Figure 8: composition of garnet and clinopyroxene from the mafic rocks. (a) and (b) show garnet 1131composition, plotted with and without the spessartine component in (b). Arrows in (b) emphasize the 1132increase in Mn in the symplectite rimming garnet cores (see also Fig. 7a-c), mostly at the expense of 1133Fe. (c) and (d) show clinopyroxene composition, from point EPMA measurements as circles and from 1134EPMA mapping as small dots coloured according to their $\mathrm{Al}$ content, corresponding to CPX1 (Al-rich 1135cores) and CPX2 (Al-poor rims) in Fig. 7b (sample MA-14-38). Crosses in (d) indicate average 1136composition and 2-sigma standard deviation of each clinopyroxene generation measured on the area of 1137Fig. 7b. 

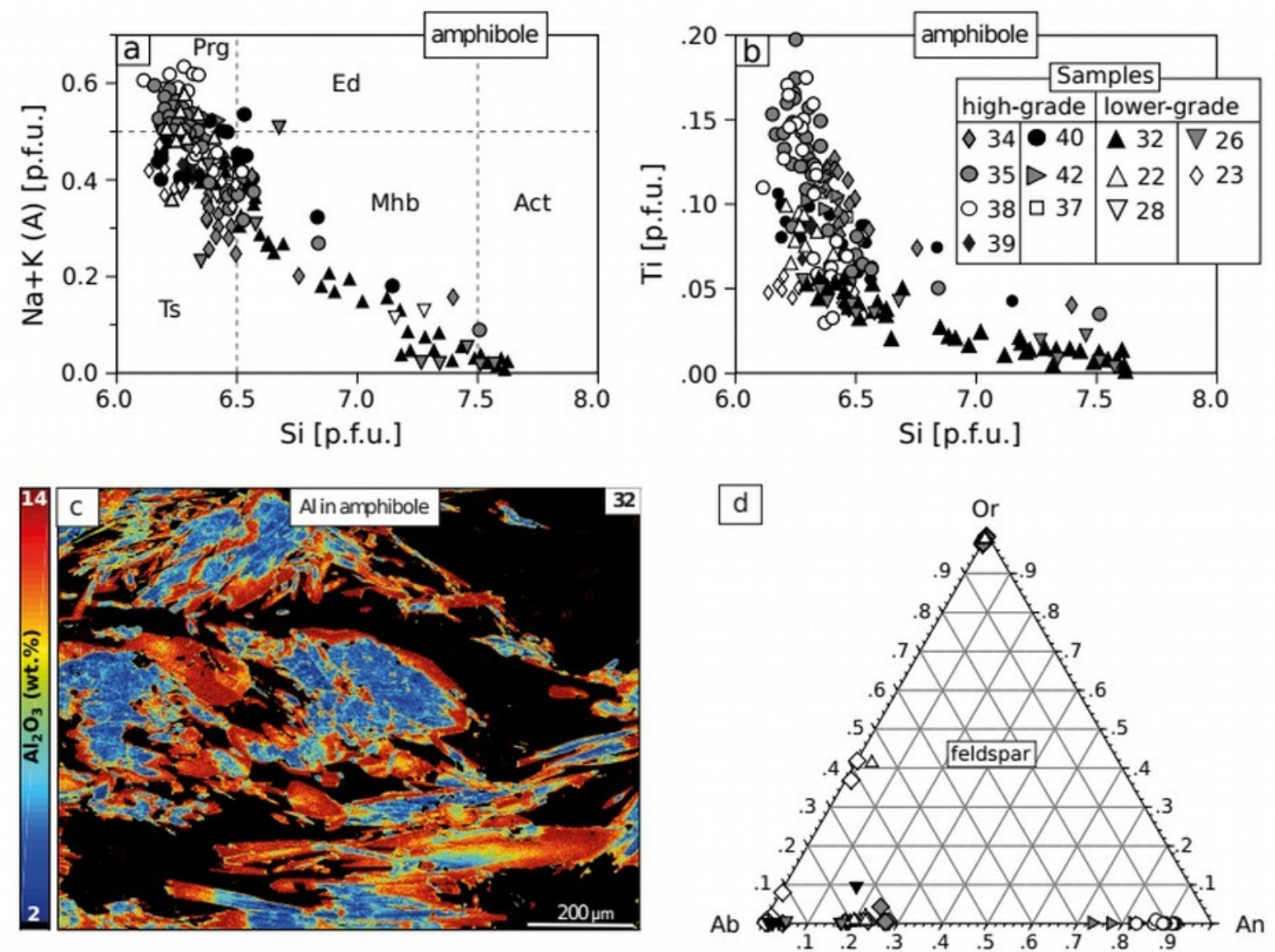

1140Figure 9: Composition of amphibole and feldspar in high-grade and lower-grade mafic rocks of the 1141metamorphic sole of Mont Albert. (a) Alkali content of the A site of amphibole versus Si content, 1142linked to Ti content (b). Samples close to the contact with the peridotite have highest alkali and Ti. (c) 1143Al content of amphibole in sample MA-14-32 (top of lower-grade unit along the Cascapedia river) 1144showing actinolite-rich cores and pargasite-rich rims, measured with SEM. Numbers on the left-hand 1145side colour scale indicate concentration as obtained from EPMA point analysis. (d) Composition of 1146feldspar. 

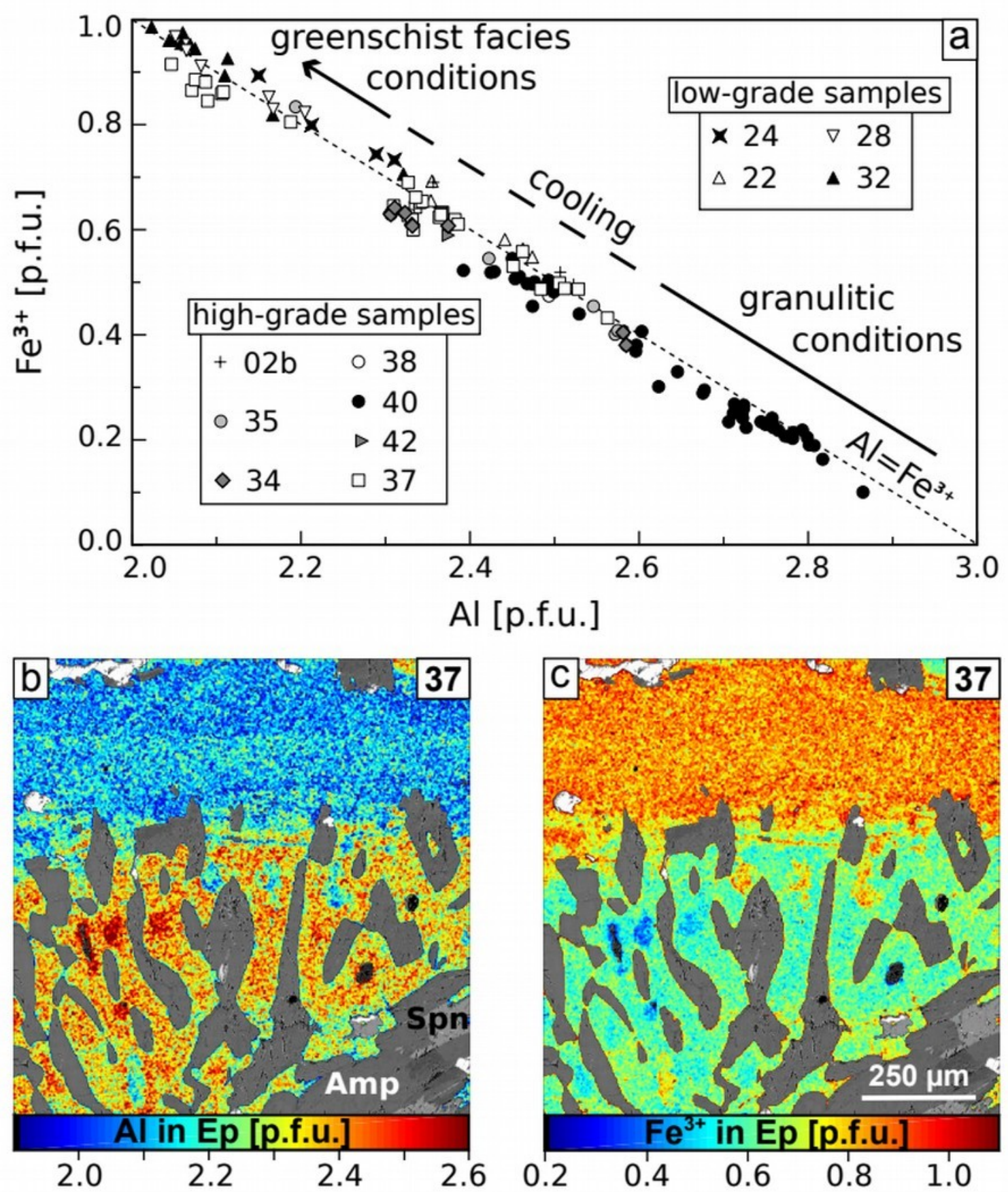

1149Figure 10: Composition of epidote in high-grade and lower-grade mafic rocks of the metamorphic sole 1150of Mont Albert. (a) Compilation of analyses showing $\mathrm{Fe}^{3+}$ content versus $\mathrm{Al}$ content. (b) and (c) show 1151map views of $\mathrm{Al}$ and $\mathrm{Fe}^{3+}$ content of epidote in sample MA-14-37, laid over a back-scattered electron 1152EPMA image of an amphibole-epidote symplectite cross-cut by an epidote vein (horizontal, on top). 
$1153 \mathrm{Fe}^{3+}$-rich epidote is found in the vein, Al-rich epidote in the symplectite, with the cores of symplectite 1154crystals being richest in $\mathrm{Al}$. 

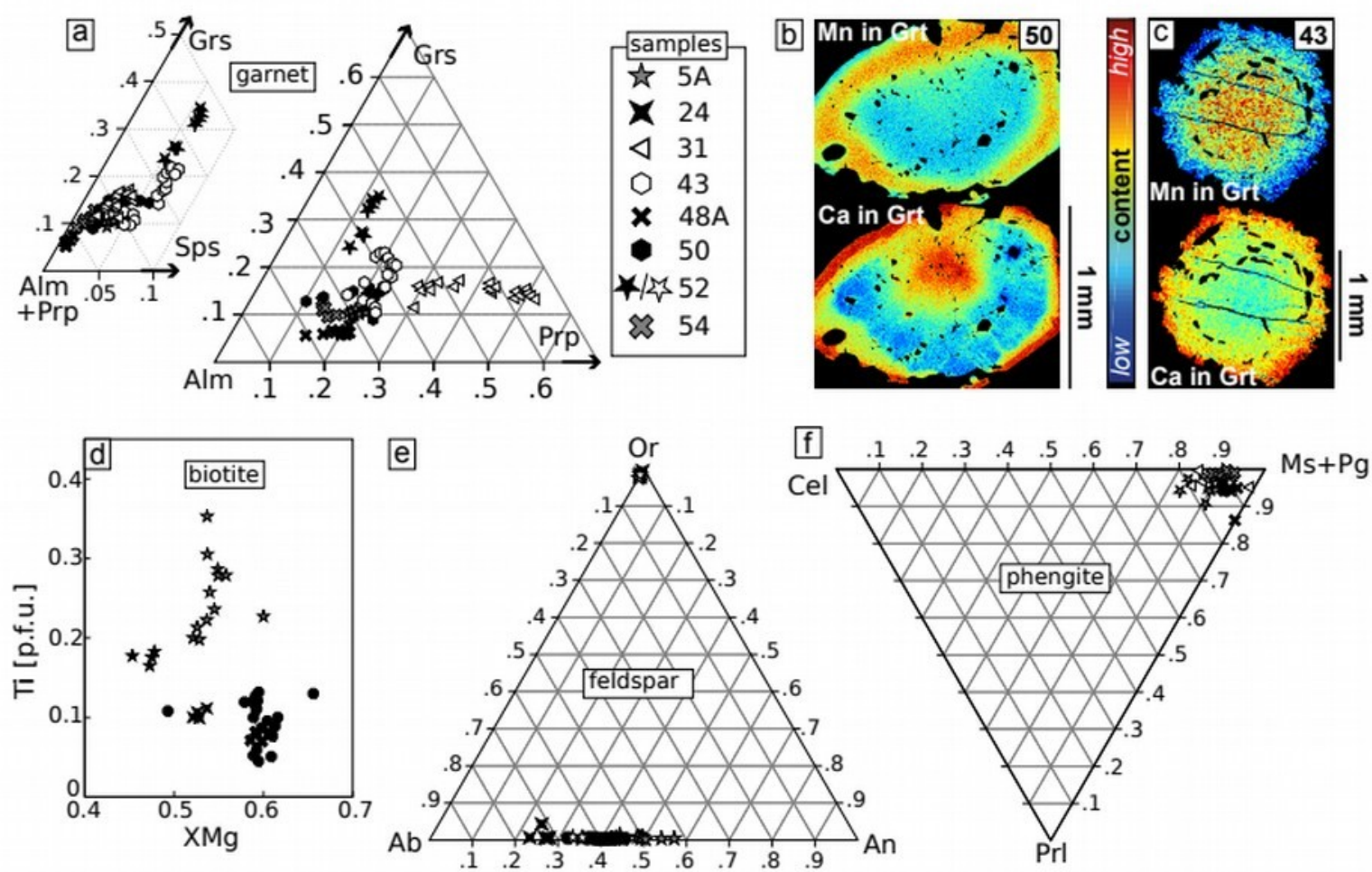

1157Figure 11: Composition of minerals in metasediments from the metamorphic sole of the Mont Albert 1158complex. (a) Garnet composition, plotted with and without the spessartine component. Zoning in 1159garnet is shown as measured with SEM for Ca and Mn in high-grade samples in (b) and (c), all scaled 1160on the colourbar in b. (d) Ti content versus Xmg of biotite. (e) Composition of feldspar. (f) 1161Composition of phengite. 


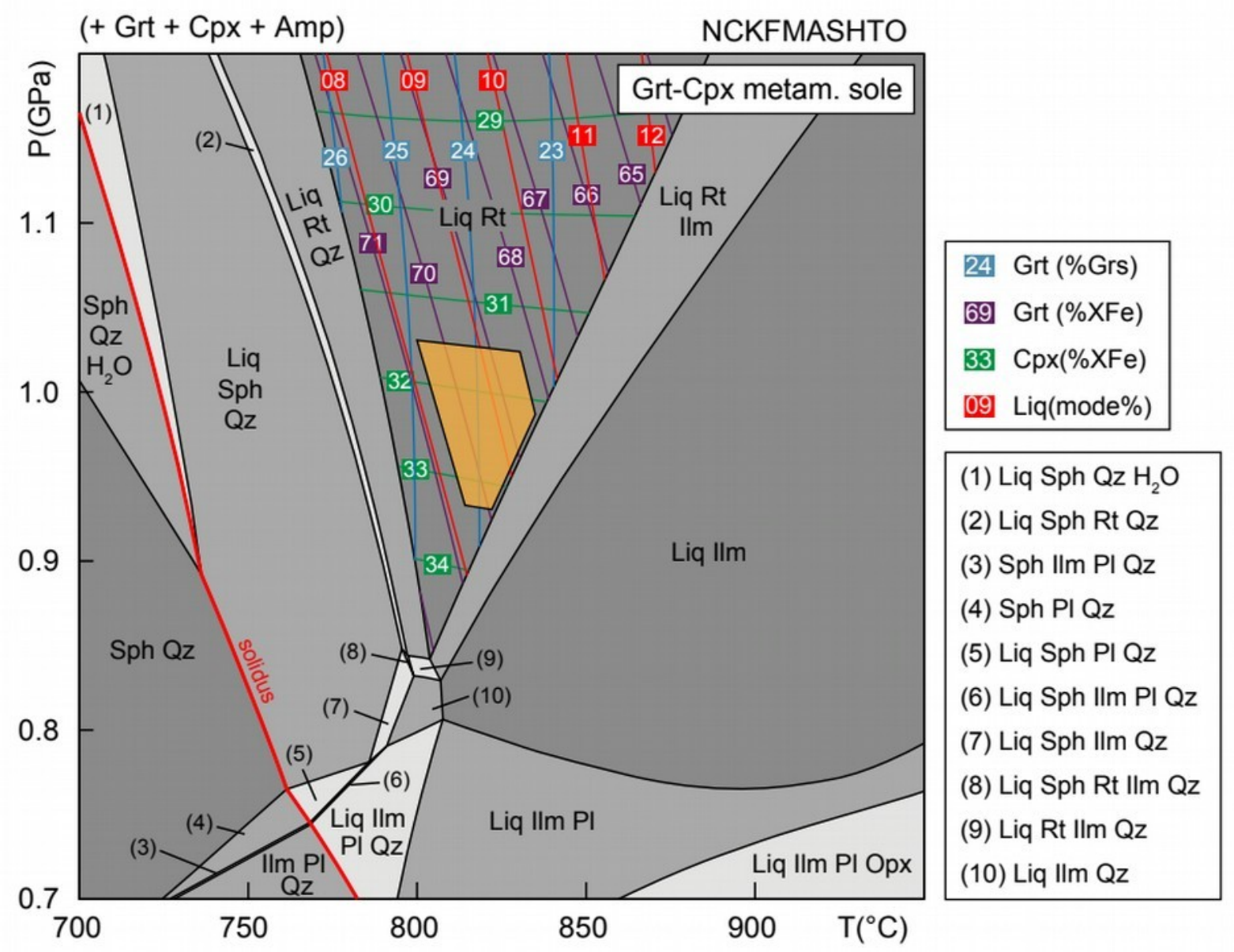

1164Figure 12: pressure-temperature pseudosection in NCKFMASHTO for a mafic rock representative of 1165the garnet-bearing high-grade unit. Garnet, clinopyroxene and amphibole are present throughout the 1166pseudosection. The solidus is drawn with a red line and isopleths are shown for garnet, clinopyroxene 1167and melt fraction as discussed in the text. The orange field highlights pressure-temperature conditions 1168matching the petrography. 


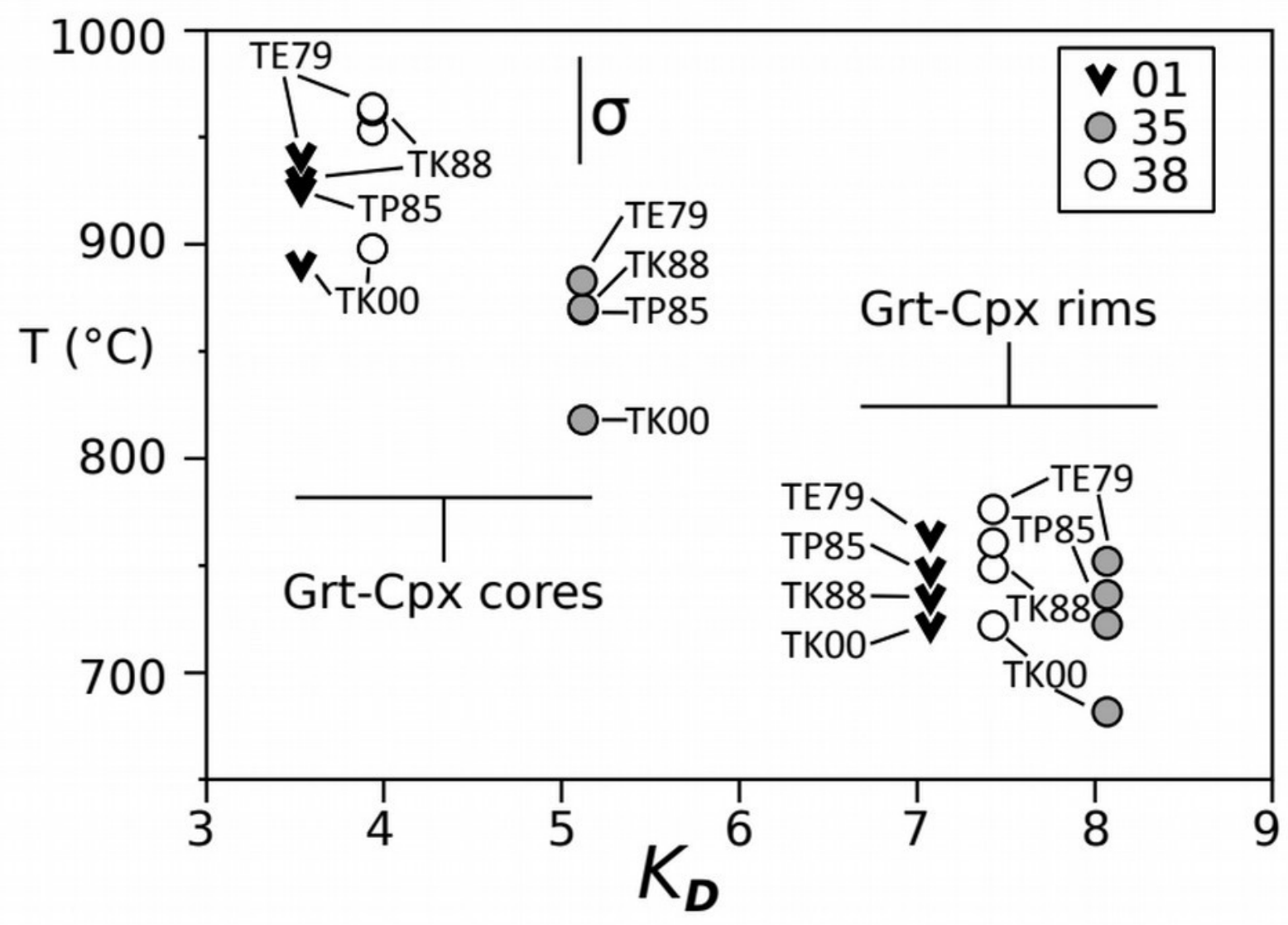

1171Figure 13: Results of garnet-clinopyroxene thermometry, calculated at fixed pressure of 0.95 GPa 1172using the calibrations of Ellis and Green (1979, TE79), Powell (1985, TP85), Krogh Ravna (1988, $1173 T K 88 ; 2000$, TK00). Uncertainties on temperature estimates are consistently of the order of $50^{\circ} \mathrm{C}$, 1174including $\sim 10^{\circ} \mathrm{C}$ uncertainty originating from pressure estimates. 

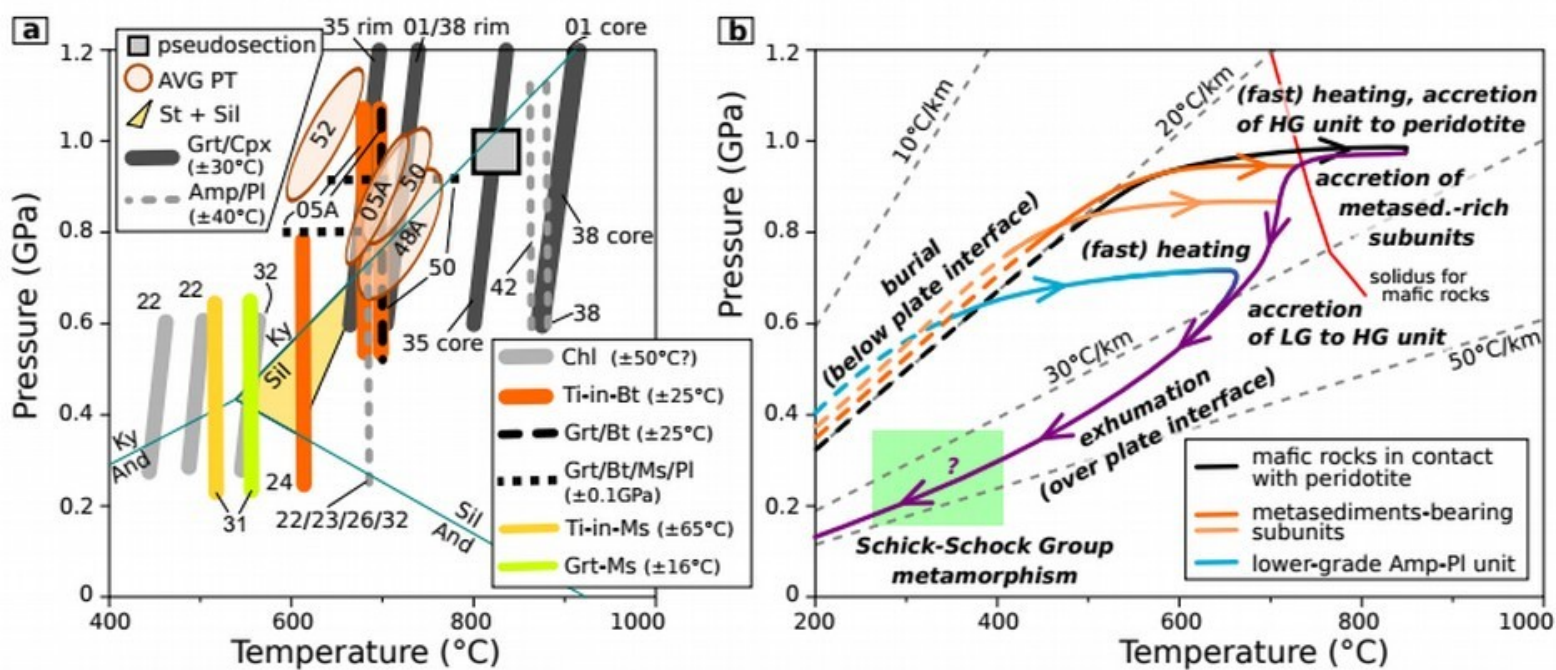

1177Figure 14: Compilation of thermobarometric estimates obtained in this study and inferred pressure1178temperature paths. (a) Thermobarometry results for mafic rocks (grey shades) and metasediments 1179(orange / green), reported as envelopes for AVG-PT, a box for results from the pseudosection (Fig. 118011), and sticks for chlorite thermometry, empirical pair equilibria and Ti solubility. Stability of 1181alumina-silicates from White et al. (2014a). (b) Pressure-temperature paths of subunits from the 1182metamorphic sole, leading to an apparent inverted metamorphic gradient. Rocks on top of the 1183metamorphic sole are subject to higher peak conditions than rocks structurally further from the contact 1184to the peridotite. All rocks all exhumed along the same path. The total number of subunits is unknown 1185and shown as three subunits with the higher-grade unit for readability. Note the different temperature 1186scales in (a) and (b). 

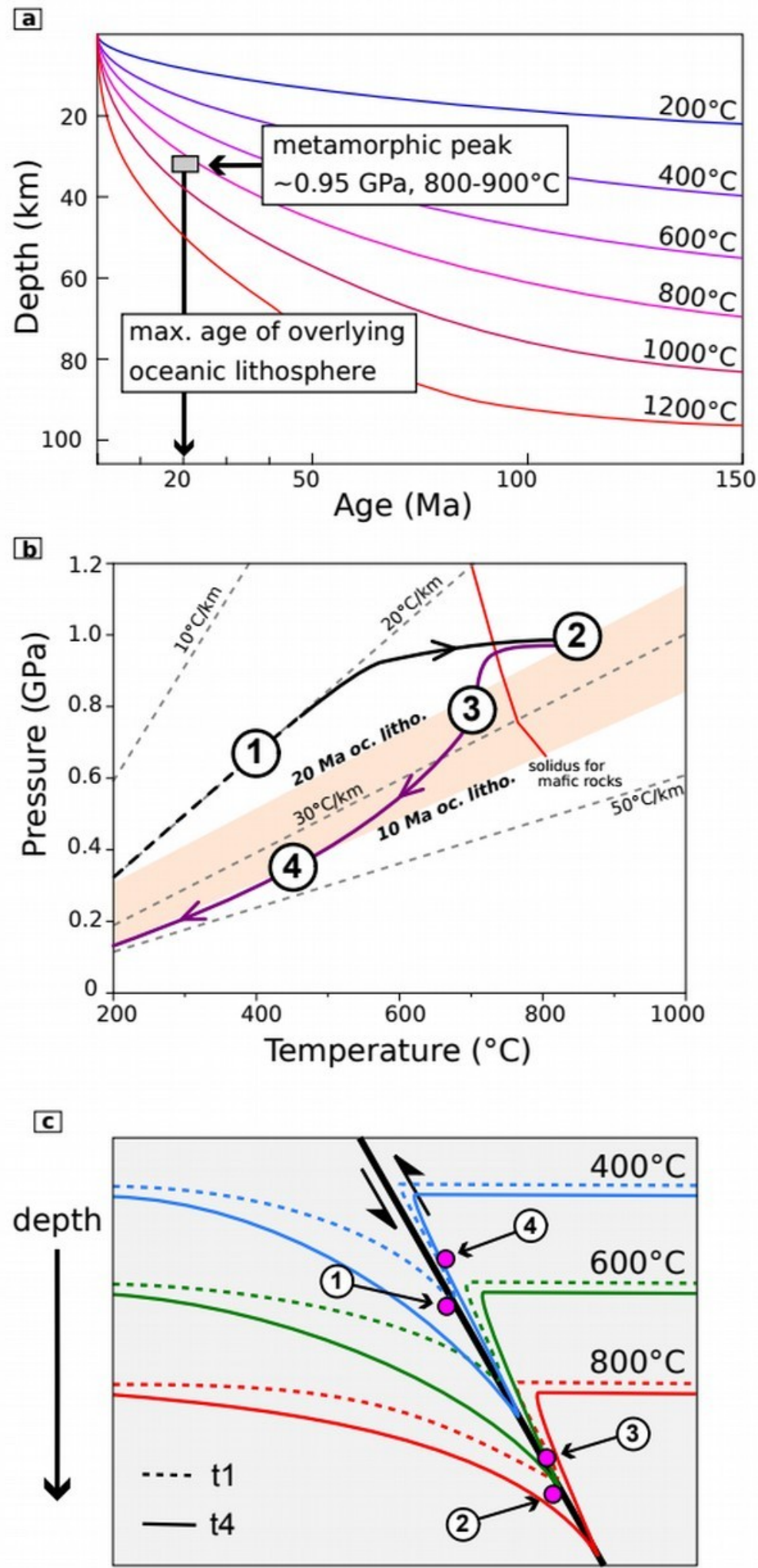

1189Figure 15: estimate of the evolution of the thermal structure of the lithosphere during metamorphic 1190sole creation. (a) Peak metamorphic conditions compared to temperature-depth profile of the oceanic 
1191lithosphere as a function of age (from McKenzie et al., 2005). (b) Pressure-temperature evolution of 1192the high-grade unit, with four steps constraining the temperature evolution close to the interface, as 1193schematized in (c), where the plate boundary is sketched in black and isotherms are shown for step 1 1194(t1, dotted line) and step 4 (t4, solid line). 
Table 1. Selected representative analyses of amphibole

Unit

High Grade Unit

\begin{tabular}{|c|c|c|c|c|c|c|c|c|}
\hline Sample & MA-14-34 & MA-14-35 & MA-14-38 & MA-14-39 & MA-14-40 & MA-14-42 & MA-12-22 & MA-14-23 \\
\hline Analysis \# & 46 & 13 & 111 & 10 & 125 & 140 & 114 & 30 \\
\hline $\mathrm{SiO}_{2}$ & 43,09 & 41,67 & 44,21 & 42,92 & 43,30 & 42,77 & 42,36 & 41,35 \\
\hline $\mathrm{TiO}_{2}$ & 0,81 & 1,51 & 0,73 & 0,79 & 0,84 & 1,03 & 0,89 & 0,50 \\
\hline $\mathrm{Al}_{2} \mathrm{O}_{3}$ & 12,07 & 13,85 & 12,38 & 14,19 & 13,72 & 12,74 & 14,12 & 12,88 \\
\hline $\mathrm{Cr}_{2} \mathrm{O}_{3}$ & 0,05 & 0,01 & 0,10 & 0,04 & 0,56 & 0,04 & 0,08 & 0,09 \\
\hline $\mathrm{FeO}$ & 15,19 & 14,74 & 13,47 & 12,49 & 9,60 & 15,32 & 15,85 & 19,63 \\
\hline $\mathrm{MnO}$ & 0,24 & 0,06 & 0,14 & 0,07 & 0,40 & 0,21 & 0,28 & 0,43 \\
\hline $\mathrm{MgO}$ & 10,70 & 10,51 & 11,82 & 11,77 & 12,85 & 10,52 & 10,37 & 8,68 \\
\hline $\mathrm{CaO}$ & 11,58 & 11,84 & 11,67 & 11,86 & 12,27 & 11,61 & 11,21 & 10,89 \\
\hline $\mathrm{Na}_{2} \mathrm{O}$ & 1,84 & 1,92 & 1,73 & 1,49 & 1,76 & 1,91 & 2,02 & 1,79 \\
\hline $\mathrm{K}_{2} \mathrm{O}$ & 0,26 & 0,30 & 0,21 & 0,72 & 0,40 & 0,43 & 0,92 & 0,52 \\
\hline$\Sigma$ & 95,84 & 96,42 & 96,46 & 96,37 & 95,71 & 96,59 & 98,10 & 96,74 \\
\hline Ox. & 23 & 23 & 23 & 23 & 23 & 23 & 23 & 23 \\
\hline $\mathrm{Si}$ & 6,45 & 6,21 & 6,50 & 6,32 & 6,39 & 6,37 & 6,21 & 6,20 \\
\hline Aliv & 1,55 & 1,79 & 1,50 & 1,68 & 1,61 & 1,63 & 1,79 & 1,80 \\
\hline Alvi & 0,58 & 0,65 & 0,64 & 0,78 & 0,78 & 0,61 & 0,65 & 0,48 \\
\hline $\mathrm{Ti}$ & 0,09 & 0,17 & 0,08 & 0,09 & 0,09 & 0,12 & 0,10 & 0,06 \\
\hline $\mathrm{Cr}$ & 0,01 & 0,00 & 0,01 & 0,00 & 0,07 & 0,01 & 0,01 & 0,01 \\
\hline $\mathrm{Fe}^{s+}$ & 0,48 & 0,40 & 0,47 & 0,42 & 0,12 & 0,44 & 0,67 & 1,08 \\
\hline $\mathrm{Fe}^{2+}$ & 1,43 & 1,44 & 1,19 & 1,11 & 1,07 & 1,47 & 1,27 & 1,38 \\
\hline $\mathrm{Mn}$ & 0,03 & 0,01 & 0,02 & 0,01 & 0,05 & 0,03 & 0,04 & 0,05 \\
\hline $\mathrm{Mg}$ & 2,39 & 2,34 & 2,59 & 2,58 & 2,83 & 2,34 & 2,27 & 1,94 \\
\hline $\mathrm{Ca}$ & 1,86 & 1,89 & 1,84 & 1,87 & 1,94 & 1,85 & 1,76 & 1,75 \\
\hline $\mathrm{Na}$ & 0,53 & 0,56 & 0,49 & 0,43 & 0,50 & 0,55 & 0,57 & 0,52 \\
\hline $\mathrm{K}$ & 0,05 & 0,06 & 0,04 & 0,14 & 0,08 & 0,08 & 0,17 & 0,10 \\
\hline$\Sigma$ cat. & 15,44 & 15,50 & 15,37 & 15,43 & 15,52 & 15,49 & 15,51 & 15,37 \\
\hline$[\mathrm{Na}+\mathrm{K}]^{\mathrm{A}}$ & 0,44 & 0,50 & 0,37 & 0,43 & 0,52 & 0,49 & 0,51 & 0,37 \\
\hline $\mathrm{XMg}$ & 0,63 & 0,62 & 0,69 & 0,70 & 0,73 & 0,61 & 0,64 & 0,58 \\
\hline
\end{tabular}


Low Grade Unit

\begin{tabular}{|c|c|c|c|c|c|}
\hline \multicolumn{2}{|c|}{ MA-14-26 } & \multicolumn{2}{|c|}{ MA-14-28 } & \multicolumn{2}{|c|}{ MA-14-32 } \\
\hline 88 & 78 & 61 & 56 & 127 & 125,1 \\
\hline 42,58 & 52,68 & 43,36 & 50,68 & 43,61 & 53,47 \\
\hline 0,50 & 0,07 & 0,54 & 0,16 & 0,47 & 0,12 \\
\hline 12,70 & 3,20 & 11,48 & 5,42 & 12,81 & 3,25 \\
\hline 0,05 & 0,00 & 0,03 & 0,04 & 0,01 & 0,00 \\
\hline 16,84 & 11,73 & 17,81 & 13,06 & 16,29 & 11,90 \\
\hline 0,36 & 0,24 & 0,26 & 0,25 & 0,27 & 0,34 \\
\hline 10,65 & 16,53 & 10,33 & 14,86 & 10,70 & 15,97 \\
\hline 10,91 & 11,70 & 11,01 & 12,07 & 11,17 & 11,65 \\
\hline 2,03 & 0,66 & 2,00 & 0,90 & 2,03 & 0,74 \\
\hline 0,37 & 0,11 & 0,26 & 0,12 & 0,38 & 0,14 \\
\hline 97,01 & 96,90 & 97,07 & 97,55 & 97,74 & 97,59 \\
\hline 23 & 23 & 23 & 23 & 23 & 23 \\
\hline 6,27 & 7,51 & 6,42 & 7,28 & 6,38 & 7,60 \\
\hline 1,73 & 0,49 & 1,58 & 0,72 & 1,62 & 0,40 \\
\hline 0,48 & 0,05 & 0,42 & 0,20 & 0,59 & 0,15 \\
\hline 0,06 & 0,01 & 0,06 & 0,02 & 0,05 & 0,01 \\
\hline 0,01 & 0,00 & 0,00 & 0,00 & 0,00 & 0,00 \\
\hline 1,03 & 0,65 & 0,92 & 0,50 & 0,78 & 0,45 \\
\hline 1,04 & 0,75 & 1,28 & 1,07 & 1,22 & 0,96 \\
\hline 0,05 & 0,03 & 0,03 & 0,03 & 0,03 & 0,04 \\
\hline 2,34 & 3,52 & 2,28 & 3,18 & 2,33 & 3,39 \\
\hline 1,72 & 1,79 & 1,75 & 1,86 & 1,75 & 1,77 \\
\hline 0,58 & 0,18 & 0,57 & 0,25 & 0,58 & 0,20 \\
\hline 0,07 & 0,02 & 0,05 & 0,02 & 0,07 & 0,03 \\
\hline 15,37 & 14,99 & 15,37 & 15,13 & 15,40 & $\overline{15,00}$ \\
\hline 0,37 & 0,02 & 0,37 & 0,13 & 0,40 & 0,03 \\
\hline 0,69 & 0,82 & 0,64 & 0,75 & 0,66 & 0,78 \\
\hline
\end{tabular}


Table 2. Selected representative analyses of clinopyroxene.

Unit

High Grade Unit

\begin{tabular}{|c|c|c|c|c|c|c|c|c|c|}
\hline Sample & & $-14-35$ & & & MA-1 & & & MA-14-40 & MA-14-42 \\
\hline Analysis \# & 23 & 30 & 41 & 80 & 84 & 100 & 102 & 111 & 135 \\
\hline $\mathrm{SiO}_{2}$ & 47,70 & 50,37 & 47,82 & 48,35 & 50,39 & 51,40 & 51,30 & 51,12 & 50,09 \\
\hline $\mathrm{TiO}_{2}$ & 0,50 & 0,37 & 0,62 & 0,55 & 0,27 & 0,07 & 0,13 & 0,25 & 0,34 \\
\hline $\mathrm{Al}_{2} \mathrm{O}_{3}$ & 6,92 & 3,96 & 6,80 & 6,61 & 4,08 & 3,54 & 3,94 & 4,11 & 4,43 \\
\hline $\mathrm{Cr}_{2} \mathrm{O}_{3}$ & 0,04 & 0,11 & 0,01 & 0,26 & 0,17 & 0,07 & 0,08 & 0,07 & 0,01 \\
\hline $\mathrm{FeO}$ & 10,66 & 8,77 & 10,68 & 9,53 & 9,58 & 8,00 & 8,55 & 6,63 & 9,76 \\
\hline $\mathrm{MnO}$ & 0,18 & 0,15 & 0,20 & 0,17 & 0,22 & 0,26 & 0,24 & 0,54 & 0,28 \\
\hline $\mathrm{MgO}$ & 9,89 & 12,15 & 10,50 & 10,43 & 11,64 & 12,51 & 12,35 & 13,04 & 11,05 \\
\hline $\mathrm{CaO}$ & 22,03 & 23,10 & 22,65 & 22,42 & 22,79 & 23,14 & 22,75 & 23,20 & 22,74 \\
\hline $\mathrm{Na}_{2} \mathrm{O}$ & 0,76 & 0,62 & 0,62 & 0,79 & 0,60 & 0,54 & 0,62 & 0,72 & 0,76 \\
\hline $\mathrm{K}_{2} \mathrm{O}$ & 0,02 & 0,00 & 0,00 & 0,00 & 0,01 & 0,01 & 0,00 & 0,01 & 0,01 \\
\hline$\Sigma$ & 98,69 & 99,61 & 99,91 & 99,12 & 99,76 & 99,54 & 99,95 & 99,68 & 99,47 \\
\hline Ox. & 6 & 6 & 6 & 6 & 6 & 6 & 6 & 6 & 6 \\
\hline $\mathrm{Si}$ & 1,83 & 1,90 & 1,81 & 1,84 & 1,90 & 1,93 & 1,92 & 1,91 & 1,90 \\
\hline $\mathrm{Ti}$ & 0,01 & 0,01 & 0,02 & 0,02 & 0,01 & 0,00 & 0,00 & 0,01 & 0,01 \\
\hline $\mathrm{Al}_{\text {tot }}$ & 0,31 & 0,18 & 0,30 & 0,30 & 0,18 & 0,16 & 0,17 & 0,18 & 0,20 \\
\hline $\mathrm{Cr}$ & 0,00 & 0,00 & 0,00 & 0,01 & 0,00 & 0,00 & 0,00 & 0,00 & 0,00 \\
\hline $\mathrm{Fe}_{\mathrm{tot}}$ & 0,34 & 0,28 & 0,34 & 0,30 & 0,30 & 0,25 & 0,27 & 0,21 & 0,31 \\
\hline $\mathrm{Mn}$ & 0,01 & 0,00 & 0,01 & 0,01 & 0,01 & 0,01 & 0,01 & 0,02 & 0,01 \\
\hline $\mathrm{Mg}$ & 0,56 & 0,68 & 0,59 & 0,59 & 0,65 & 0,70 & 0,69 & 0,72 & 0,62 \\
\hline $\mathrm{Ca}$ & 0,90 & 0,93 & 0,92 & 0,91 & 0,92 & 0,93 & 0,91 & 0,93 & 0,92 \\
\hline $\mathrm{Na}$ & 0,06 & 0,05 & 0,05 & 0,06 & 0,04 & 0,04 & 0,05 & 0,05 & 0,06 \\
\hline $\mathrm{K}$ & 0,00 & 0,00 & 0,00 & 0,00 & 0,00 & 0,00 & 0,00 & 0,00 & 0,00 \\
\hline$\Sigma$ cat. & 4,03 & 4,03 & 4,04 & 4,03 & 4,02 & 4,01 & 4,01 & 4,02 & 4,02 \\
\hline $\mathrm{XMg}$ & 0,62 & 0,71 & 0,64 & 0,66 & 0,68 & 0,74 & 0,72 & 0,78 & 0,67 \\
\hline
\end{tabular}


Table 3. Selected representative analyses of feldspar.

\begin{tabular}{|c|c|c|c|c|c|c|c|c|c|}
\hline Mineral & $\mathrm{Pl}$ & P1 & $\mathrm{Pl}$ & Or & Or & $\mathrm{Pl}$ & Pl & $\mathrm{Pl}$ & $\mathrm{Pl}$ \\
\hline Unit & \multicolumn{9}{|c|}{ High Grade Unit } \\
\hline Sample & MA-14-34 & MA-14-3 & & MA-14-39 & MA-14-40 & MA-14-42 & MA-12-22 & MA-14-23 & MA- \\
\hline Analysis \# & 60 & 89 & 73 & 12 & 109 & 134 & 104 & 20 & 41 \\
\hline $\mathrm{SiO}_{2}$ & 68,87 & 47,26 & 45,71 & 64,39 & 64,74 & 47,21 & 61,96 & 62,61 & 60,42 \\
\hline $\mathrm{TiO}_{2}$ & 0,00 & 0,00 & 0,00 & 0,00 & 0,00 & 0,00 & 0,00 & 0,00 & 0,00 \\
\hline $\mathrm{Al}_{2} \mathrm{O}_{3}$ & 19,89 & 33,52 & 34,93 & 18,50 & 18,53 & 33,10 & 24,14 & 23,34 & 24,83 \\
\hline $\mathrm{Cr}_{2} \mathrm{O}_{3}$ & 0,00 & 0,01 & 0,00 & 0,00 & 0,03 & 0,03 & 0,01 & 0,00 & 0,01 \\
\hline $\mathrm{FeO}$ & 0,00 & 0,00 & 0,00 & 0,00 & 0,00 & 0,00 & 0,08 & 0,48 & 0,25 \\
\hline $\mathrm{MnO}$ & 0,00 & 0,00 & 0,00 & 0,00 & 0,00 & 0,00 & 0,00 & 0,00 & 0,00 \\
\hline $\mathrm{MgO}$ & 0,00 & 0,00 & 0,00 & 0,00 & 0,00 & 0,00 & 0,00 & 0,00 & 0,00 \\
\hline $\mathrm{CaO}$ & 0,22 & 17,06 & 18,99 & 0,00 & 0,02 & 17,10 & 4,99 & 4,48 & 5,85 \\
\hline $\mathrm{Na}_{2} \mathrm{O}$ & 11,42 & 1,91 & 0,98 & 0,04 & 0,08 & 1,83 & 9,36 & 9,47 & 8,81 \\
\hline $\mathrm{K}_{2} \mathrm{O}$ & 0,04 & 0,00 & 0,01 & 16,23 & 15,61 & 0,02 & 0,14 & 0,07 & 0,11 \\
\hline$\Sigma$ & 100,43 & 99,75 & 100,61 & 99,15 & 99,01 & 99,29 & 100,67 & 100,46 & 100,29 \\
\hline Ox. & 8 & 8 & 8 & 8 & 8 & 8 & 8 & 8 & 8 \\
\hline $\mathrm{Si}$ & 2,99 & 2,17 & 2,09 & 2,99 & 3,00 & 2,18 & 2,74 & 2,77 & 2,69 \\
\hline $\mathrm{Ti}$ & 0,00 & 0,00 & 0,00 & 0,00 & 0,00 & 0,00 & 0,00 & 0,00 & 0,00 \\
\hline $\mathrm{Al}_{\text {tot }}$ & 1,02 & 1,81 & 1,89 & 1,01 & 1,01 & 1,80 & 1,26 & 1,22 & 1,30 \\
\hline $\mathrm{Cr}$ & 0,00 & 0,00 & 0,00 & 0,00 & 0,00 & 0,00 & 0,00 & 0,00 & 0,00 \\
\hline $\mathrm{Fe}_{\text {tot }}$ & 0,00 & 0,00 & 0,00 & 0,00 & 0,00 & 0,00 & 0,00 & 0,00 & 0,00 \\
\hline $\mathrm{Mn}$ & 0,00 & 0,00 & 0,00 & 0,00 & 0,00 & 0,00 & 0,00 & 0,00 & 0,00 \\
\hline $\mathrm{Mg}$ & 0,00 & 0,00 & 0,00 & 0,00 & 0,00 & 0,00 & 0,00 & 0,00 & 0,00 \\
\hline $\mathrm{Ca}$ & 0,01 & 0,84 & 0,93 & 0,00 & 0,00 & 0,85 & 0,24 & 0,21 & 0,28 \\
\hline $\mathrm{Na}$ & 0,96 & 0,17 & 0,09 & 0,00 & 0,01 & 0,16 & 0,80 & 0,81 & 0,76 \\
\hline $\mathrm{K}$ & 0,00 & 0,00 & 0,00 & 0,96 & 0,92 & 0,00 & 0,01 & 0,00 & 0,01 \\
\hline$\overline{\Sigma \text { cat. }}$ & 4,98 & 5,00 & 5,00 & 4,98 & 4,95 & $\overline{5,00}$ & 5,04 & 5,02 & 5,04 \\
\hline XAn & 0,01 & 0,83 & 0,91 & 0,00 & 0,00 & 0,84 & 0,23 & 0,21 & 0,27 \\
\hline $\mathrm{XAb}$ & 0,99 & 0,17 & 0,09 & 0,00 & 0,01 & 0,16 & 0,77 & 0,79 & 0,73 \\
\hline XOr & 0,00 & 0,00 & 0,00 & 1,00 & 0,99 & 0,00 & 0,01 & 0,00 & 0,01 \\
\hline
\end{tabular}




\begin{tabular}{|c|c|c|c|c|}
\hline Or & $\mathrm{Pl}$ & $\mathrm{Pl}$ & $\mathrm{Pl}$ & $\mathrm{Pl}$ \\
\hline \multicolumn{5}{|c|}{ Low Grade Unit } \\
\hline $14-24$ & MA-14-25 & MA-14-26 & MA-1 & \\
\hline 49 & 56 & 86 & 147 & 133 \\
\hline 63,57 & 63,95 & 63,14 & 62,90 & 68,37 \\
\hline 0,00 & 0,00 & 0,00 & 0,00 & 0,00 \\
\hline 18,19 & 23,14 & 22,71 & 24,04 & 20,58 \\
\hline 0,01 & 0,00 & 0,00 & 0,00 & 0,02 \\
\hline 0,18 & 0,17 & 0,31 & 0,27 & 0,31 \\
\hline 0,00 & 0,00 & 0,00 & 0,00 & 0,00 \\
\hline 0,00 & 0,00 & 0,00 & 0,00 & 0,00 \\
\hline 0,00 & 4,16 & 3,92 & 5,00 & 0,74 \\
\hline 0,20 & 10,13 & 10,24 & 9,33 & 11,82 \\
\hline 16,85 & 0,09 & 0,05 & 0,07 & 0,05 \\
\hline 99,00 & 101,63 & 100,36 & 101,60 & 101,89 \\
\hline 8 & 8 & 8 & 8 & 8 \\
\hline 2,98 & 2,79 & 2,79 & 2,75 & 2,95 \\
\hline 0,00 & 0,00 & 0,00 & 0,00 & 0,00 \\
\hline 1,01 & 1,19 & 1,18 & 1,24 & 1,04 \\
\hline 0,00 & 0,00 & 0,00 & 0,00 & 0,00 \\
\hline 0,00 & 0,00 & 0,00 & 0,00 & 0,00 \\
\hline 0,00 & 0,00 & 0,00 & 0,00 & 0,00 \\
\hline 0,00 & 0,00 & 0,00 & 0,00 & 0,00 \\
\hline 0,00 & 0,19 & 0,19 & 0,23 & 0,03 \\
\hline 0,02 & 0,86 & 0,88 & 0,79 & 0,99 \\
\hline 1,01 & 0,00 & 0,00 & 0,00 & 0,00 \\
\hline 5,02 & 5,04 & 5,05 & 5,02 & 5,02 \\
\hline 0,00 & 0,18 & 0,17 & 0,23 & 0,03 \\
\hline 0,02 & 0,81 & 0,82 & 0,77 & 0,96 \\
\hline 0,98 & 0,00 & 0,00 & 0,00 & 0,00 \\
\hline
\end{tabular}


Table 4. Selected representative analyses of micas

\begin{tabular}{|c|c|c|c|c|c|c|c|c|}
\hline \multirow{3}{*}{$\begin{array}{l}\text { Min. } \\
\text { Loc. } \\
\text { Smpl. }\end{array}$} & $\mathrm{Bt}$ & Ms & \multirow[t]{2}{*}{ Ms } & \multicolumn{5}{|c|}{ Ms } \\
\hline & \multicolumn{2}{|c|}{ Lower Grade Unit } & & \multicolumn{5}{|c|}{ Metasediment } \\
\hline & MA-14-24 & MA-1 & & \multicolumn{3}{|c|}{ MA-14-05a } & \multicolumn{2}{|c|}{ MA-14-50 } \\
\hline Anal. & 37 & 8 & 9 & 16 & 36 & 34 & 74 & 80 \\
\hline $\mathrm{SiO}_{2}$ & 36,14 & 46,20 & 45,59 & 34,62 & 35,43 & 48,14 & 37,04 & 45,83 \\
\hline $\mathrm{TiO}_{2}$ & 1,94 & 0,26 & 0,24 & 3,03 & 2,53 & 0,00 & 2,36 & 0,27 \\
\hline $\mathrm{Al}_{2} \mathrm{O}_{3}$ & 17,80 & 31,83 & 33,46 & 18,60 & 19,07 & 34,52 & 18,20 & 33,87 \\
\hline $\mathrm{Cr}_{2} \mathrm{O}_{3}$ & 0,01 & 0,02 & 0,02 & 0,03 & 0,05 & 0,00 & 0,09 & 0,00 \\
\hline $\mathrm{FeO}$ & 17,25 & 3,10 & 3,35 & 16,17 & 16,79 & 1,32 & 15,54 & 2,99 \\
\hline $\mathrm{MnO}$ & 0,20 & 0,05 & 0,00 & 0,06 & 0,08 & 0,04 & 0,10 & 0,01 \\
\hline $\mathrm{MgO}$ & 11,21 & 1,28 & 0,96 & 10,52 & 11,46 & 0,31 & 12,80 & 1,05 \\
\hline $\mathrm{CaO}$ & 0,01 & 0,06 & 0,02 & 0,07 & 0,00 & 0,50 & 0,09 & 0,00 \\
\hline $\mathrm{Na}_{2} \mathrm{O}$ & 0,10 & 1,14 & 1,16 & 0,30 & 0,25 & 1,03 & 0,16 & 1,13 \\
\hline $\mathrm{K}_{2} \mathrm{O}$ & 9,67 & 9,75 & 9,71 & 8,99 & 9,35 & 9,20 & 8,89 & 9,58 \\
\hline$\Sigma$ & 94,33 & 93,68 & 94,50 & 92,41 & 95,01 & 95,07 & 95,27 & 94,74 \\
\hline Ox. & 22 & 11 & 11 & 22 & 22 & 11 & 22 & 22 \\
\hline $\mathrm{Si}$ & 5,51 & 3,16 & 3,09 & 5,36 & 5,34 & 3,18 & 5,51 & 3,09 \\
\hline $\mathrm{Ti}$ & 0,22 & 0,01 & 0,01 & 0,35 & 0,29 & 0,00 & 0,26 & 0,01 \\
\hline $\mathrm{Al}_{\text {tot }}$ & 3,20 & 2,56 & 2,67 & 3,39 & 3,39 & 2,69 & 3,19 & 2,69 \\
\hline $\mathrm{Cr}$ & 0,00 & 0,00 & 0,00 & 0,00 & 0,01 & 0,00 & 0,01 & 0,00 \\
\hline $\mathrm{Fe}_{\text {tot }}$ & 2,20 & 0,18 & 0,19 & 2,09 & 2,12 & 0,07 & 1,93 & 0,17 \\
\hline $\mathrm{Mn}$ & 0,03 & 0,00 & 0,00 & 0,01 & 0,01 & 0,00 & 0,01 & 0,00 \\
\hline $\mathrm{Mg}$ & 2,55 & 0,13 & 0,10 & 2,43 & 2,58 & 0,03 & 2,84 & 0,11 \\
\hline $\mathrm{Ca}$ & 0,00 & 0,00 & 0,00 & 0,01 & 0,00 & 0,04 & 0,01 & 0,00 \\
\hline $\mathrm{Na}$ & 0,03 & 0,15 & 0,15 & 0,09 & 0,07 & 0,13 & 0,05 & 0,15 \\
\hline $\mathrm{K}$ & 1,88 & 0,85 & 0,84 & 1,78 & 1,80 & 0,78 & 1,69 & 0,82 \\
\hline$\Sigma$ cat. & 15,62 & 7,05 & 7,06 & 15,52 & 15,61 & 6,92 & 15,50 & 7,04 \\
\hline $\mathrm{XMg}$ & 0,54 & - & & 0,54 & 0,55 & - & 0,59 & - \\
\hline XPrl & - & 0,00 & 0,01 & - & - & 0,06 & - & 0,03 \\
\hline $\mathrm{XMs}+\mathrm{XPg}$ & - & 0,84 & 0,91 & - & - & 0,82 & - & 0,91 \\
\hline Cel & - & 0,16 & 0,08 & - & - & 0,13 & - & 0,06 \\
\hline
\end{tabular}

Abbrevations after Whitney and Evans (2010). 
Table 5. Selected representative analyses of epidote.

\begin{tabular}{|c|c|c|c|c|c|c|c|}
\hline \multirow{2}{*}{$\begin{array}{l}\text { Unit } \\
\text { Sample }\end{array}$} & \multicolumn{2}{|c|}{ Low grade } & \multicolumn{2}{|l|}{ Low grade } & \multicolumn{2}{|c|}{ High grade } & Low \\
\hline & MA-1 & & MA-14-22 & & MA-1 & & MA- \\
\hline Analysis \# & 135 & 136 & 90 & 107 & 7 & 70 & 46 \\
\hline $\mathrm{SiO}_{2}$ & 37,37 & 37,41 & 38,06 & 38,19 & 37,89 & 37,40 & 37,23 \\
\hline $\mathrm{TiO}_{2}$ & 0,03 & 0,04 & 0,19 & 0,09 & 0,14 & 0,12 & 0,10 \\
\hline $\mathrm{Al}_{2} \mathrm{O}_{3}$ & 21,02 & 22,11 & 26,72 & 25,63 & 27,23 & 25,13 & 24,27 \\
\hline $\mathrm{Cr}_{2} \mathrm{O}_{3}$ & 0,03 & 0,00 & 0,10 & 0,19 & 0,01 & 0,02 & 0,00 \\
\hline $\mathrm{FeO}$ & 14,87 & 14,20 & 8,62 & 10,62 & 7,37 & 10,37 & 11,13 \\
\hline $\mathrm{MnO}$ & 0,12 & 0,21 & 0,13 & 0,32 & 0,25 & 0,49 & 0,37 \\
\hline $\mathrm{MgO}$ & 0,00 & 0,00 & 0,00 & 0,00 & 0,12 & 0,03 & 0,02 \\
\hline $\mathrm{CaO}$ & 23,24 & 23,39 & 23,48 & 23,07 & 23,17 & 22,56 & 22,76 \\
\hline $\mathrm{Na}_{2} \mathrm{O}$ & 0,02 & 0,00 & 0,04 & 0,01 & 0,00 & 0,05 & 0,02 \\
\hline $\mathrm{K}_{2} \mathrm{O}$ & 0,00 & 0,00 & 0,01 & 0,00 & 0,01 & 0,00 & 0,01 \\
\hline$\Sigma$ & 96,71 & 97,37 & 97,35 & 98,12 & 96,19 & 96,18 & 95,90 \\
\hline Ox. & 12,5 & 12,5 & 12,5 & 12,5 & 12,5 & 12,5 & 12,5 \\
\hline $\mathrm{Si}$ & 3,00 & 2,98 & 2,98 & 2,98 & 2,99 & 2,97 & 2,98 \\
\hline $\mathrm{Ti}$ & 0,00 & 0,00 & 0,01 & 0,01 & 0,01 & 0,01 & 0,01 \\
\hline $\mathrm{Al}_{\text {tot }}$ & 1,99 & 2,07 & 2,46 & 2,35 & 2,53 & 2,36 & 2,29 \\
\hline $\mathrm{Cr}$ & 0,00 & 0,00 & 0,01 & 0,01 & 0,00 & 0,00 & 0,00 \\
\hline $\mathrm{Fe} 3+$ & 1,00 & 0,94 & 0,56 & 0,69 & 0,49 & 0,69 & 0,74 \\
\hline $\mathrm{Mn}$ & 0,01 & 0,01 & 0,01 & 0,02 & 0,02 & 0,03 & 0,02 \\
\hline $\mathrm{Mg}$ & 0,00 & 0,00 & 0,00 & 0,00 & 0,01 & 0,00 & 0,00 \\
\hline $\mathrm{Ca}$ & 2,00 & 2,00 & 1,97 & 1,93 & 1,96 & 1,92 & 1,95 \\
\hline $\mathrm{Na}$ & 0,00 & 0,00 & 0,01 & 0,00 & 0,00 & 0,01 & 0,00 \\
\hline $\mathrm{K}$ & 0,00 & 0,00 & 0,00 & 0,00 & 0,00 & 0,00 & 0,00 \\
\hline$\Sigma$ cat. & 8,00 & 8,01 & 8,00 & 7,99 & 8,00 & 8,00 & 8,00 \\
\hline
\end{tabular}




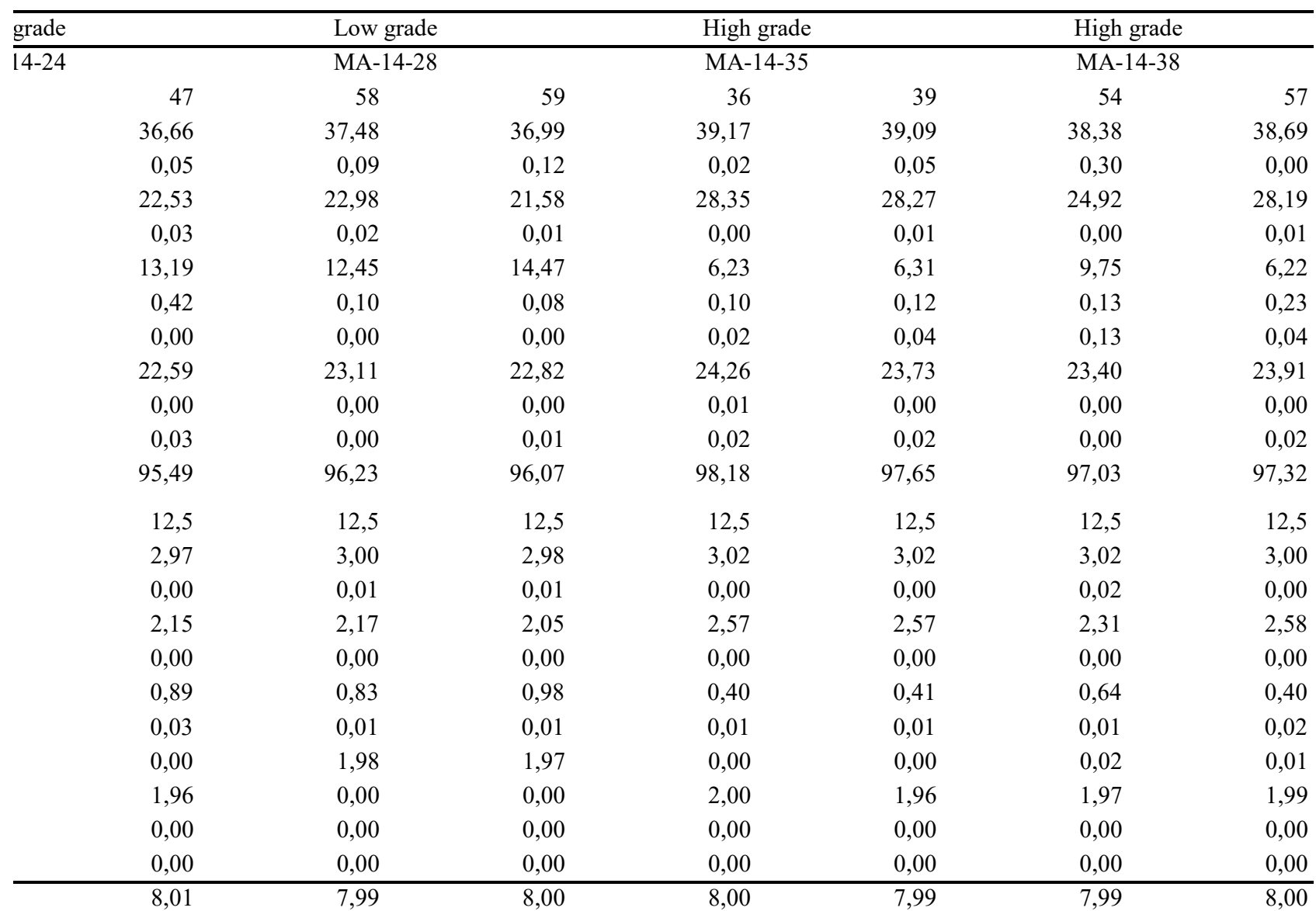




\begin{tabular}{|c|c|c|c|c|c|c|}
\hline \multicolumn{3}{|c|}{ High grade } & \multicolumn{4}{|c|}{ High grade } \\
\hline \multicolumn{2}{|c|}{ MA-14-40 } & & \multicolumn{3}{|c|}{ MA-14-37 } & \\
\hline 120 & 121 & 122 & 51 & 3 & 9 & 11 \\
\hline 38,95 & 39,21 & 38,99 & 37,81 & 37,47 & 38,23 & 38,33 \\
\hline 0,05 & 0,02 & 0,17 & 0,28 & 0,09 & 0,25 & 0,01 \\
\hline 29,54 & 31,67 & 28,68 & 22,01 & 21,44 & 25,30 & 27,73 \\
\hline 0,00 & 0,03 & 0,25 & 0,02 & $-0,01$ & 0,04 & $-0,01$ \\
\hline 3,60 & 1,56 & 4,64 & 12,97 & 13,52 & 9,82 & 6,59 \\
\hline 0,18 & 0,05 & 0,19 & 0,18 & 0,16 & 0,09 & 0,16 \\
\hline 0,08 & 0,00 & 0,09 & 0,02 & $-0,03$ & 0,07 & 0,03 \\
\hline 24,08 & 24,57 & 23,96 & 23,51 & 22,70 & 23,75 & 23,60 \\
\hline 0,00 & 0,05 & 0,03 & 0,01 & 0,01 & 0,04 & 0,02 \\
\hline 0,00 & 0,02 & 0,02 & 0,01 & 0,00 & 0,02 & $-0,02$ \\
\hline 96,49 & 97,19 & 97,02 & 96,82 & 95,34 & 97,62 & 96,44 \\
\hline 12,5 & 12,5 & 12,5 & 12,5 & 12,5 & 12,5 & 12,5 \\
\hline 3,03 & 3,01 & 3,03 & 3,02 & 3,03 & 2,99 & 3,01 \\
\hline 0,00 & 0,00 & 0,01 & 0,02 & 0,01 & 0,01 & 0,00 \\
\hline 2,71 & 2,86 & 2,62 & 2,07 & 2,05 & 2,34 & 2,56 \\
\hline 0,00 & 0,00 & 0,02 & 0,00 & 0,00 & 0,00 & 0,00 \\
\hline 0,23 & 0,10 & 0,30 & 0,87 & 0,92 & 0,64 & 0,43 \\
\hline 0,01 & 0,00 & 0,01 & 0,01 & 0,01 & 0,01 & 0,01 \\
\hline 0,01 & 0,00 & 0,01 & 0,00 & 0,00 & 0,01 & 0,00 \\
\hline 2,01 & 2,02 & 1,99 & 2,01 & 1,97 & 1,99 & 1,98 \\
\hline 0,00 & 0,01 & 0,01 & 0,00 & 0,00 & 0,01 & 0,00 \\
\hline 0,00 & 0,00 & 0,00 & 0,00 & 0,00 & 0,00 & 0,00 \\
\hline 8,00 & 8,01 & 8,00 & 8,00 & 7,98 & 8,00 & 8,00 \\
\hline
\end{tabular}


Table 6. Selected representative analyses of garnet.

Unit

Mafic rocks, high grade unit

\begin{tabular}{lrrrrrrrr} 
Sample & \multicolumn{3}{c}{ MA-14-39 } & \multicolumn{2}{c}{ MA-14-35 } & \multicolumn{2}{c}{ MA-14-38 } & \multicolumn{2}{c}{ MA-14-34 } & MA-14-37 \\
\cline { 2 - 8 } Analysis & 4 & 5 & 5 & 46 & 92 & 3 & 78 & 31 \\
$\mathrm{SiO}_{2}$ & 39,39 & 38,97 & 38,64 & 38,09 & 38,77 & 38,93 & 38,64 & 37,70 \\
$\mathrm{TiO}_{2}$ & 0,00 & 0,00 & 0,04 & 0,07 & 0,02 & 0,03 & 0,01 & 0,06 \\
$\mathrm{Al}_{2} \mathrm{O}_{3}$ & 21,65 & 21,59 & 20,66 & 20,65 & 21,04 & 21,76 & 21,01 & 20,92 \\
$\mathrm{Cr}_{2} \mathrm{O}_{3}$ & 0,03 & 0,05 & 0,03 & 0,00 & 0,02 & 0,08 & 0,00 & $-0,02$ \\
$\mathrm{FeO}$ & 23,79 & 23,60 & 22,76 & 23,75 & 21,85 & 20,85 & 24,48 & 26,96 \\
$\mathrm{MnO}$ & 1,08 & 1,00 & 1,24 & 1,68 & 2,63 & 1,35 & 2,40 & 2,90 \\
$\mathrm{MgO}$ & 7,69 & 7,66 & 5,49 & 4,69 & 4,74 & 7,15 & 5,17 & 3,35 \\
$\mathrm{CaO}$ & 6,72 & 6,72 & 10,97 & 10,83 & 10,86 & 10,44 & 7,55 & 7,56 \\
$\mathrm{Na}{ }_{2} \mathrm{O}$ & 0,00 & 0,00 & 0,03 & 0,00 & 0,00 & 0,00 & $-0,02$ & $-0,01$ \\
$\mathrm{~K}_{2} \mathrm{O}$ & 0,01 & 0,01 & 0,02 & 0,00 & 0,00 & 0,00 & $-0,01$ & 0,02 \\
$\Sigma$ & 100,36 & 99,60 & 99,88 & 99,75 & 99,93 & 100,59 & 99,24 & 99,46 \\
$\mathrm{Ox}$. & 12 & 12 & 12 & 12 & 12 & 12 & 12 & 12 \\
$\mathrm{Si}$ & 3,02 & 3,01 & 3,01 & 2,99 & 3,02 & 2,98 & 3,04 & 3,00 \\
$\mathrm{Ti}$ & 0,00 & 0,00 & 0,00 & 0,00 & 0,00 & 0,00 & 0,00 & 0,00 \\
$\mathrm{Al}$ & 1,96 & 1,96 & 1,90 & 1,91 & 1,93 & 1,96 & 1,95 & 1,97 \\
$\mathrm{Cr}$ & 0,00 & 0,00 & 0,00 & 0,00 & 0,00 & 0,00 & 0,00 & 0,00 \\
$\mathrm{Fe}$ & 1,52 & 1,52 & 1,48 & 1,56 & 1,42 & 1,33 & 1,61 & 1,80 \\
$\mathrm{Mn}$ & 0,07 & 0,07 & 0,08 & 0,11 & 0,17 & 0,09 & 0,16 & 0,20 \\
$\mathrm{Mg}$ & 0,88 & 0,88 & 0,64 & 0,55 & 0,55 & 0,81 & 0,61 & 0,40 \\
$\mathrm{Ca}$ & 0,55 & 0,56 & 0,92 & 0,91 & 0,91 & 0,86 & 0,64 & 0,65 \\
$\mathrm{Na}$ & 0,00 & 0,00 & 0,00 & 0,00 & 0,00 & 0,00 & 0,00 & 0,00 \\
$\mathrm{~K}$ & 0,00 & 0,00 & 0,00 & 0,00 & 0,00 & 0,00 & 0,00 & 0,00 \\
\hline$\Sigma$ cat. & 8,00 & 8,01 & 8,04 & 8,04 & 8,01 & 8,04 & 7,99 & 8,01
\end{tabular}



Table 6. Selected representative analyses of minor phases.

\begin{tabular}{|c|c|c|c|c|c|c|c|}
\hline Mineral & $\mathrm{St}$ & Scp & Mrg-rich Phg & Mrg-rich Phg & Mrg-rich Phg & Pmp & Chl \\
\hline Unit & \multicolumn{2}{|c|}{ Metasediment } & & High grade & & High grade & High \\
\hline Sample & MA-14-14 & MA-14-12 & & MA-14-02 & & MA-14-34 & MA- \\
\hline Analysis \# & 27 & 13 & 9 & 10 & 72 & 64 & 84 \\
\hline $\mathrm{SiO}_{2}$ & 27,04 & 45,17 & 41,86 & 36,14 & 44,38 & 36,51 & 26,26 \\
\hline $\mathrm{TiO}_{2}$ & 0,65 & 0,04 & 0,09 & 0,01 & 0,32 & 0,04 & 0,04 \\
\hline $\mathrm{Al}_{2} \mathrm{O}_{3}$ & 53,76 & 24,84 & 42,50 & 45,69 & 39,69 & 21,67 & 20,85 \\
\hline $\mathrm{Cr}_{2} \mathrm{O}_{3}$ & 0,00 & 0,00 & 0,00 & 0,01 & 0,00 & 0,03 & 0,03 \\
\hline $\mathrm{FeO}$ & 12,84 & 0,17 & 0,86 & 1,02 & 1,12 & 8,91 & 22,90 \\
\hline $\mathrm{MnO}$ & 0,18 & 0,00 & 0,02 & 0,00 & 0,00 & 0,13 & 0,37 \\
\hline $\mathrm{MgO}$ & 1,78 & 0,00 & 0,18 & 0,38 & 0,14 & 2,27 & 17,49 \\
\hline $\mathrm{CaO}$ & 0,00 & 16,54 & 3,06 & 7,02 & 1,16 & 22,64 & 0,03 \\
\hline $\mathrm{Na}_{2} \mathrm{O}$ & 0,00 & 4,04 & 6,43 & 4,18 & 6,43 & 0,02 & 0,00 \\
\hline $\mathrm{K}_{2} \mathrm{O}$ & 0,00 & 0,00 & 0,73 & 0,42 & 1,61 & 0,00 & 0,04 \\
\hline$\Sigma$ & 96,25 & 90,80 & 95,74 & 94,86 & 94,85 & 92,22 & 88,02 \\
\hline Ox. & 22 & 24 & 11 & 11 & 11 & 12 & 14 \\
\hline $\mathrm{Si}$ & 3,63 & 6,94 & 2,71 & 2,39 & 2,89 & 2,99 & 2,72 \\
\hline $\mathrm{Ti}$ & 0,07 & 0,00 & 0,00 & 0,00 & 0,02 & 0,00 & 0,00 \\
\hline $\mathrm{Al}_{\text {tot }}$ & 8,52 & 4,50 & 3,24 & 3,56 & 3,04 & 2,09 & 2,55 \\
\hline $\mathrm{Cr}$ & 0,00 & 0,00 & 0,00 & 0,00 & 0,00 & 0,00 & 0,00 \\
\hline $\mathrm{Fe}_{\text {tot }}$ & 1,44 & 0,02 & 0,05 & 0,06 & 0,06 & 0,61 & 1,98 \\
\hline $\mathrm{Mn}$ & 0,02 & 0,00 & 0,00 & 0,00 & 0,00 & 0,01 & 0,03 \\
\hline $\mathrm{Mg}$ & 0,36 & 0,00 & 0,02 & 0,04 & 0,01 & 0,28 & 2,70 \\
\hline $\mathrm{Ca}$ & 0,00 & 2,72 & 0,21 & 0,50 & 0,08 & 1,98 & 0,00 \\
\hline $\mathrm{Na}$ & 0,00 & 1,20 & 0,81 & 0,54 & 0,81 & 0,00 & 0,00 \\
\hline $\mathrm{K}$ & 0,00 & 0,00 & 0,06 & 0,04 & 0,13 & 0,00 & 0,00 \\
\hline$\overline{\Sigma \text { cat. }}$ & 14,04 & 15,40 & 7,10 & 7,11 & 7,05 & 7,97 & 10,00 \\
\hline $\mathrm{XMg}$ & 0,20 & - & 0,27 & 0,40 & 0,19 & 0,31 & 0,58 \\
\hline
\end{tabular}




\begin{tabular}{rr}
\hline \multicolumn{2}{c}{ Chl } \\
grade & \\
\hline $14-22$ & 85 \\
& 26,33 \\
& 0,06 \\
20,44 \\
0,02 \\
23,18 \\
0,43 \\
17,50 \\
0,06 \\
0,03 \\
0,02 \\
88,07 \\
14 \\
2,73 \\
0,00 \\
2,50 \\
0,00 \\
2,01 \\
0,04 \\
2,71 \\
0,01 \\
0,01 \\
0,00 \\
10,01 \\
0,57 \\
\hline
\end{tabular}

